2273 




\section{ACCOUNT}

OF A

\section{VOYAGE OF DISCOVERY \\ TO THE NORTH-EAST OF \\ SIBERIA,}

\section{THE FROZEN OCEAN,}

AND THE

NORTH-EAST SEA.

BY

\section{GAWRILA $\underset{1}{1}$ ARYTSCHEW,}

RUSSIAN IMPERIAL MAJOR-GENERAL TO THE EXPEDITION.

TRANSLATED FROM THE RUSSIAN,

AND EMBELLISHED WITH ENGRAVINGS。

\section{LONDON:}

PRINTED FOR RICHARD PHILLIPS, 6, BRIDGE STREFT,

BIACKTRIARS,

By J. G. Bänard, 57, Snore-hill.

1806. 
E34143.

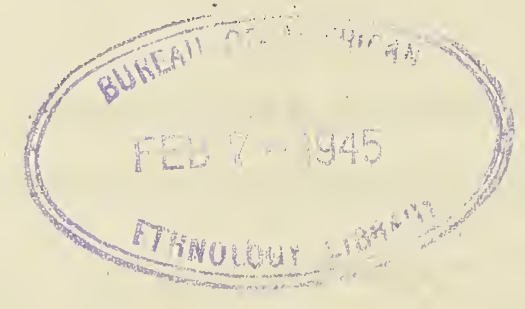




\section{AUTHOR'S PREFACE.}

There is no sea with which our age is so imperfectly acquainted as the Frozen Ocean; and no empire which has more powerful motives and resources for extending its information, in this quarter, than Russia. Although the government has made several efforts, at different periods, to attain this object, yet none of their expeditions, except the first two, undertaken by. Captain Behring, for the purpose of discovery, have brought them nearer the desired point; owing to the inexperience of those who planned and executed them, and who were neither of them aware of the endless difficulties to be combated in a boisterous element, and a corner of the glowe so imperfectly known.

One grand impediment to their success was the size of their vessels, which were very well adapted for crossing the main on voyages of discovery, but could ill serve the purpose of passing through shallows, and making minute observations on the shores. By the removal of this evil I flatter myself that not a single bay, island, or mountain, has A 2 
escaped our notice, on the coasts of which we have taken a survey, and that we have, in addition to this, been enabled to rectify the mistakes of former. navigators.

During the eight years of our absence $I$ had made it my daily practice to note down in my journal every thing that appeared to me worthy of observation, without any intention, however remote, of committing my remarks to the press; but the urgent persuasions of my friends, combined with the gracious commands of his Imperial Majesty, have at length over-ruled my disinclination to give them publicity. I now submit this my humble effort at contributing. to the general good, with the fullest reliance on the indulgence of a candid public。 


\title{
A VOYAGE OF DISCOVERY
}

ro

\author{
SIBERIA, \&c.
}

CHAP. I.

ARRANGEMENTS FOR THE EXPEDITION.MY DEPARTURE. -JOURNEY TO IRKUTSK AND JAKUTSK.-REMARKS ON THE LATTER PLACE.-OF THE JAKUTS' UNINHABITED PLACES, AND HORSES. SHAMAN.

O

N the 8th of August, 1785, our late revered sovereign, Catherine the Great, whose matemal care extended to the remotest comers of her realin, was pleased to communicate, in an ukase, the plan and destination of our voyage to the board of admiralty. In this she gave her directions for a geographical and astronomical expedition to proceed to the north-eastern part of Russia, for the purpose of taking the latitude and longrude of the mouth of the river Kolyma, together with a inap of its banks, comprehending the whole chain of 'T'schukotish mountains, the east ern cape, and the numerous islands seatiered in the eastem occan, as far as the shores of America; and, finally, of obtaining a more accurate acquaintauce vith the seas separating the continent of Irkutsi from the coast of America.

Commodore Joseph Bilings was appointsd chief of the expedition: the other officers were, Robert Hall, Gavrila Sarytschew, and Christian Behring; liectenants; Anthony Batakow and Sergei Bramikow, steersmen; Michaila Rohocck, first surgeon; Mark Sauer, secretary; Joseph Edwards, mechenic; Luka Woronin, drawing-master; and Wasslei Siwgow, chaplain. Doctor Kal Mark succeeded assessor Patrin in the department of natural history, whose ill heahh obliged him to resign his situation at Irkutsk.

Agreeably to the arrangements of the empress, Commodore Billings was to be twice promoted during the voyage, and the inferior officers once. The whole crew, according to their respective rank, were to receive duble pay during the voyage; 
with the additional recompence of a year's double pay on their departure and return. Besides which, the superior officers were to have a pension for life; and those who might be disabled in the service, were to retire on half-pay. The wives and children also of such as died during the expedition, were to receive the half pay of their husbands or fathers; the wives until their second marriage, or death; and the children until they came of age.

The various preparations for the expedition lasted six months; all the necessary astronomical instruments being ordered from England: while much time was occupied in collecting the toys and trifling presents for the savage inhabitants, as well as medals of gold, silver, and copper, which were struck for the same purpose.

About the middle of September, I was dispatched with some workmen from Petersburgh to Ochotsk, to forward the requisite preparations at the different places. The badness of the roads greatly retarded my progress as far as Tobolsk, but this impediment ccased with the setting in of the cold weather. On the syd of October, I exchanged my wheeled vehicles for sleriges, with which I passed over the river Irtysch. The ice in the $\mathrm{Ob}$ not being set on the 28th, we crossed it in the boats, but not without very great danger. During the rest of my journey I found all the other rivers passable by the sledges, except the Angara, in the neighbourhood of Irkutsk, which, from the violence of the stream, remains open till December, and I reached this place on the loth of November*.

My business here was to examine the state of the transport vessels and building materials, that whatever was wanting miglit be provided by order of the governor-general; and, in case of a deficiency in timber, hides were to be procured for making the baidars. These are large boats of a peculiar construction, made either of wood or hides.

In the latter case, the sides of the boat are covered with the skins of sea-animals instead of planks. They carry from eight to sixteen oars, but have no rudder.

After having made the necessary enquiries, and obtained an open order from the governor-general, to all the provincial magistrates, authorising them to afford me every possible assistance, I leit Irkutsk in December, and arrived in Jakutsk on the loth of January, after a journey still more tedious than the former. The road was very good as far as the river Lena; but our pas. sage over the rough ice of this stream to the town of Alukmar,

* Irkutsk is 6016 wersts, or 859 German miles, or 4295 English miles from Petersburgh; accordingly the author went at the rate of 16 German, or 30 English miles a day. 
was extremely troublesome. Between Alukmar and Jakutsk, I experienced no inconvenience from the roads, but much from the horses; which being used in those parts only for riding, drew our sledges on very slowly.

Jakutsk, situated on the left bank of the Lena, is the oldest of all the cities in that quarter. The ostrog*, or wooden fortress, was erected in the year 1647 , and soon afterwards the building of the town commenced. This old edifice, with its towers, is still standing, but in some places is fallen very much to decay. Within the enclosure there is a public building of stone, and a church : there are, besides, two stone churches; one by the convent, the other in the town, and two of wood. All the dwelling-houses are built of wood, in the old Russian taste, with here and there Jakutish huts interspersed between them. The want of glass for the windows is supplied either by isinglass or by bladders in the summer, and plates of ice in the vinter, frozen into frames by snow. These are continually sprinkled with water, which is quickly congealed by the extreme cold of the climate, to such a degree as to resist the strongest heat of a room. The light penetrates through these ice-windows in a similar manner as it does through glass covered with white frost.

The inhabitants of the town consist of civil officers, Boga ren Kinder †, Kosaks, Jakutish merchants, and citizens. 'The latter are principally exiles, some of whom, even among the felons, have amended their lives, and attached themselves again to civil society. In fact, this remark will generally hold good, that criminals of the lowest order, sent to Siberia for extraordinary crimes, the sight of which impresses us with horror, not only have their liberty, but use it with the greatest moderation. Many of them gain the confidence of the inhabitants, and are admitted into their houses in different capacities. They are, of course, particularly on their guard to prevent even the suspicion of doing amiss, from the apprehension of being de, livered over to perpetual labour in the mines of Nertschink + .

* The word ostrog is here translated fortress, for which the Russian have likewise the word krepost; this, however, is never used in the present work. Ostrog is the peculiar appellation for Siberian fortresses, the greater part of which are aptly enough described by the deceased Georgi, when he says, "It would be dangerous to attempt storming them, for whoever wanted to mount their greatest and only bulwark, the wooden paling, would most probably come to the ground with the whole structure about him." TR.

$+\mathbf{A}$ class of inferior nobility, existing only in Siberia, and composed of meritorious Kosaks, who have been in the service of the emperor. They owe their establishment to Peter the Great.

† Cousiderable alterations have probably taken place in this respect since that period; for even in Catherine's reign, repeated ukases were issued, to 
It is beyond all doubt, that many of these poor creatures are possessed of good hearts, and have been hurried, by some incioental or urgent circumstances, into the commission of atrocious crimes.

Heedless of the remonstrances made me against travelling that road farther in the winter season, I set off from Jakutsk on horseback, attended with a retinue of Jakuts for my guide, and pack-horses to carry my baggage and provisions; having laid in a stock for two months, and furnished myse "rording to the custom of the country, with a coat of rein eer skins as a protection against the severity of the climate.

The commander had provided me with a Kosak, who could speak Jakutish and 'Tungushish, and who served as my interpreter both with the guides and in the different districts through which I passed; and I found him every where indispensible, the Russian being neither spoken nor understood in those parts. All my countrymen, without exception, settling here, make themselves acquainted with their language for purposes of trade; a motive which cannot influence them to learn our's.

From Jakutsk to the river Aldan, 350 wersts distant, the road led me through Jakutish ulusses, or dwelling-places, over plains scattered with woods, lakes, corn-fields, and meadows. The woods, every where, consisted of larch and beechtrees. An uluss comprehends a certain number of dwellings, under the government of a Knäsck* ${ }^{*}$, or elder. We generally passed our nights in the jurts of these Knäsks, and were always received with great kindness. Mospitality is, in fact, the first virtue among the Jakuts in general. No sooner does a traveller arrive at a place, than they hasten towards him, helping him off his horse, and conducting him into their jurt, enlarging their fire,

enforce the execution of the laws against banished criminals; and, under Paul, there were very few exceptions, in which the indulgence of staying behind was granted to the condemned. "The horridest crimes," says the author, "are but too often the result of a momentary delusion, or vehement passion, particularly among uncultivated people." In corroboration of this sentiment, we shall give the following anecdote, as described by a person who saw the female alluded to;-a woman who had murdered her husband. He was a lad of 14 or 15 , imposed spon her by her feudal lord, when she was at the auc of 23 , and was constantly provoking her by blows and ill treatment, until impelled by a spirit of revenge, she seized the opportunity of his leaning over a pail of water, to force his head in, and thus suffocate him. The person who related the anecdote to the translator met with her in a fanily in Siberia, where she had nursed the children from their infancy, and was beloved by them as a mothei, notwithstanding the mark on her forelicad. She was then advanced in years, but had not gained pence of nind by length of time. The remorse of a wounded conscience still clouded her countenance, and frequently filled her eyes with tears.

+ Knäs-the diminutive of this word signifies, in Russian, a prince. 
taking off his clothes, and cleaning then from the snow, \&c. The bed is made ready for him in the most retired place, the table covered with the best their house can afford, and his comfort consulted in every particular to the utmost of their power; while to all this civility they sometimes add the present of a fox's or sable's skin. I always strove to repay their kindness by such trifles as I knew to be most acceptable. Tobacco is a great luxury with them; but they are so extravagantly fond of brandy, that when one glass is given them they make no scruple of asking for a second, and even a third. The Jakuts are probably der nold from an ancient race of Tartars not yet converted to $N_{i}\left(i_{j}\right)$ metanism. This appears evident from a similarity of their features, their mode of life, and still more their language, which approaches so nealy to the Tartar dialect, that one of my attendants, who was a Tartar, understood most of what they said without any difficulty.

The number of Jakuts who have embraced the Christian faith is not inconsiderable, yet the majority are of the poorer class, who have submitted to be baptised perhaps in order to be freed for some years from the poll-tax. The rich are not disposed to renounce a plurality of wives, nor the use of meat, butter, milk, and above all, horse-flesh, during the fasts, as enjoined by the Catholic faith. 'The latter is the greatest delicacy they can possibly conceive; and they often tell the Russians, that if they were once to make a proper meal from the flesh of a horse, they would in future prefer it to the tenderest beef. They eat the fat of horses and cows mostly raw, without any addition, and drink melted butter with the greatest avidity; which latter they regard as an excellent remedy for many disorders, and rub their sick with it when necessary. By way of pacifying a cross child, they put a piece of raw fat into its hand to suck. In summer, when the mares foal, they make their kumys from the milk, after the manner of the Tartars. Their beverage, in winter, consists of sour milk, unchurned butter, and water, which I found indeed not unpalatable. Hence it will appear, that almost all their food is composed of things forbidden by our (the Greek) church; but our priests keep the converter Jakuts very strict to their duty, and will not allow them tu touch a single article that is prohibited; but as they have neither corn, fruit, nor fish, it is almost impossible for them to abstain so rigidly. The cause, therefore, why so many $J$ akuts remain heathens, may be attributed to the indulgence of their appetites.

The Jakutish jurts are built from the ground, describing a square of more or less magnitude, according to the size of the family. They first drive three rows of poles fast into the earth,

SARYTCHEW.] 
the middle one of which is rather higher than the two on each side On these poles they lay five beams crossways and sloping, which are covered with rough planks, and afterwards with herbs, mould, and dung. The middle of the interior is generally occupied by a hearth, from whence the smoke is carried out by a sort of chimuey, composed of long thick sticks, plaistered in the inside with pitch. The wood is placed in an upright direction on the hearth, and the fire is never extinguished during the winter. Broad benches are fixed round the walls of the jurts or huts, which are divided off by partitions into sleeping places. Their homed cattle are kept in a separate building connected with the jurt by an opening, through which they pass, from whence the whole dwelling is filled with an offensive smell. The summer jurts are altogether different from the winter ones, and have another name, being called urasses; they are round and conical, made of long poles, and covered on the outside with the bark of trees.

The rich Jakuts wear the skins of reindeer, and the poor those of horses. Their dress is the same in summer and winter, except, that in the latter case they use the fur with the skin, and in the former the skin alone. Instead of a shirt they cover the breast with a cloth, and over that wear a fur waistcoat and a long coat of the same. Their breeches do not reach the knee, which has a distinct covering, fastened with thongs, and continued from the calf by a leathern buskin, over which they wear a sort of boots, called, in their language, eterbesen. Those in better circumstances decorate their hips with cloths of red or blue, trimmed quite round, and fastened to the girdle.

Whenever a Jakut sets out on a journey, he binds his large knife, fixed in a long stick, to his girdle, and takes his steel, flint, and tinder with him; the latter of which is prepared from wormwood. In the hind part of his boot he fixes his wooden pipe, having a short tube, split down the middle, for the convenience of being cleaned, and fastened with thongs. He mixes more than half saw-dust with his tobacco, the fumes of which he mostly swallows until he is thrown into a state of stupefaction. He defends this practice on the ground of its efficacy against abdomenal complaints.

The ordinary dress of the Jakutish female differs but little from that of the female; but their best garments are longer and larger than usual, being bordered with many pieces of coloured cloth and Chinese stuffs, worked with bits of silver and coppes of different figures, and edged with a broad trimming of beaver and otter's skin. For this dress they have a particular cap, embellished with three tufts of feathers. They adorn their ears with large silver rings, and form their hair into a long queue 
On the 5th of February, I stopped at the last Jakutish dwelling-place; it was the jurt of an invalid Kosak, who filled the office of clerk to the kulisk of that district, and at the same time provided the couriers and post-horses. The road further on leads through an uninhabited country of 400 versts. Although the horses appointed for us were very good, yet the Jakuts begged me to wait some days, that they might rest from the labours of the field before they entered on so long and arduous a journey. 1 yielded to their request, and they kept the creatures tied up for four days, allowing them but a very small portion of hay only once in twenty-four hours. On the 11 th, we pursued our rout through woody and marshy plains, where no sort of track was visible, nor any guide for the traveller but what the Jakuts had made for themselves. We passed over an immense tract of country, that presented nothing worthy of observation, until we came betwixt chains of lofty mountains, and followed the course of a river for many miles, either travelling along its woody banks, or crossing its ice and its islands. This single variation was succeeded by an endless plain, covered with snow so excessively deep, that our horses could not drag themselves onward withont the utmost difficulty. The Jakuts call this tract THE Sмооті, and are very anxious to hasten through it as quickly as possible, for fear of being surprized by bad weather; in which case the whole caravan might be buried in the snow: frequent instances of which were related to me by the guides. We were, however, fortunate enough to pass the perilous spot in safety, and arived at the south of the river Amog-umoggaga; which, after jouneying 35 versts farther, brought us to the river Kumkui, whose banks are covered with warm springs. Here we found a single Jakutish jurt, the dwelling of a poor peasant, who had no cattle, and lived only on the fish and partridges that are very plentiful in those parts.

My guides telling me the next morning we had only to travel ten dinschtschen*, or about 70 versts to the next place on the Omekon. It was now my turn to be anxious to hasten onwards, that 1 might reach the spot that day, and sleep once more in a warm jurt, after having spent eleven uneasy nights in the open woods and the bitter cold. I must acknowledge that this mode of travelling had become almost insupportable to me. Having been the whole day on horseback, and the whole night in the

* A dinschtscha comprehends as much country as the wandering lordes can traverse with all their effects in a day. A great dinschtscha contains about ten, and a small one about seven versts. The word appears to be of Russian extraction : denn, in Russian, signifies a day, and has in the plural din. We find also in the Russian dictionary of the A cademys poldnischtscha, to imply half a day. - $T r$. 
snow, without ever changing my linen, or taking off my clothesi during the whole time. Thirty versts beyond our last night's abode, we passed the river Conta; and after crossing verdant meadows, reached the first jurts late in the evening.

My resolution was to have taken a little repose here, but learning that the knäsk of the district lived 40 versts farther, I remounted next morning, and set off with fresh vigour. On our way we had occasion to cross a great chain of mountains, named Atbas, to which the Jakuts pay homage, as in fact they do to all distinguished mountains, by depositing offerings of horse-hair on the trees. My guides did not omit this ceremony, each Jakut tearing out some hairs from his horse's tail, or mane, and hanging them on the nearest branches of the trees.

Our horses were so jaded from hard labour and want of food that they carried us with difficulty the last stage to Omekon. During the whole of the journey they were allowed but two hours in the morning before day-break for grazing, being tied up the rest of the night as soon as we alighted; and the grass which they kicked up with their hoofs was so withered and rotten as to have lost ail its nutritive quality; but in some places, even this miserable fodder was not to be found, so that I am persuaded the poor beasts did not get in the trrelve days as much food as they ought to have had in twenty-four hours. I learnt, however, from experience, that, without such a precaution, they would not have gone half the way; for some of the horses, through the negligence of the guides, having rolled themselve in the snow while the sweat was upon them, were covered the next morning with such large ulcers upon their backs, that they could not bear either a saddle or any other burrlen : the Jakuts left them unguarded in the wood, intending to take them on their return in case they had recovered, but if not, they were still obliged to carry their owners.

On reaching Omekon, I put up at the jurt of an invalid Ko$\$ a k$, clerk to the knäsk of that place. I was here informed that the deep snow would prevent me pursuing the journey to Ochotsk on horseback. Some Kosaks had just been making an attempt to go this road with the post, and after losing all their horses, were trying to get back on snow-shoes, when they fortunately met with the Reindeer-'Iunguses, who thus saved their lives, and conveyed them to Ochotsk. Reilideer, which are in general use among the tribes in these parts for passing from one place to another, are very well calculated for the purpose, being detained neither by the deepest snows in the winter, nor the wides marshes in the summer. I therefore gladly consented to wait antil the return of the mersenger, dispatched to the Tun- 



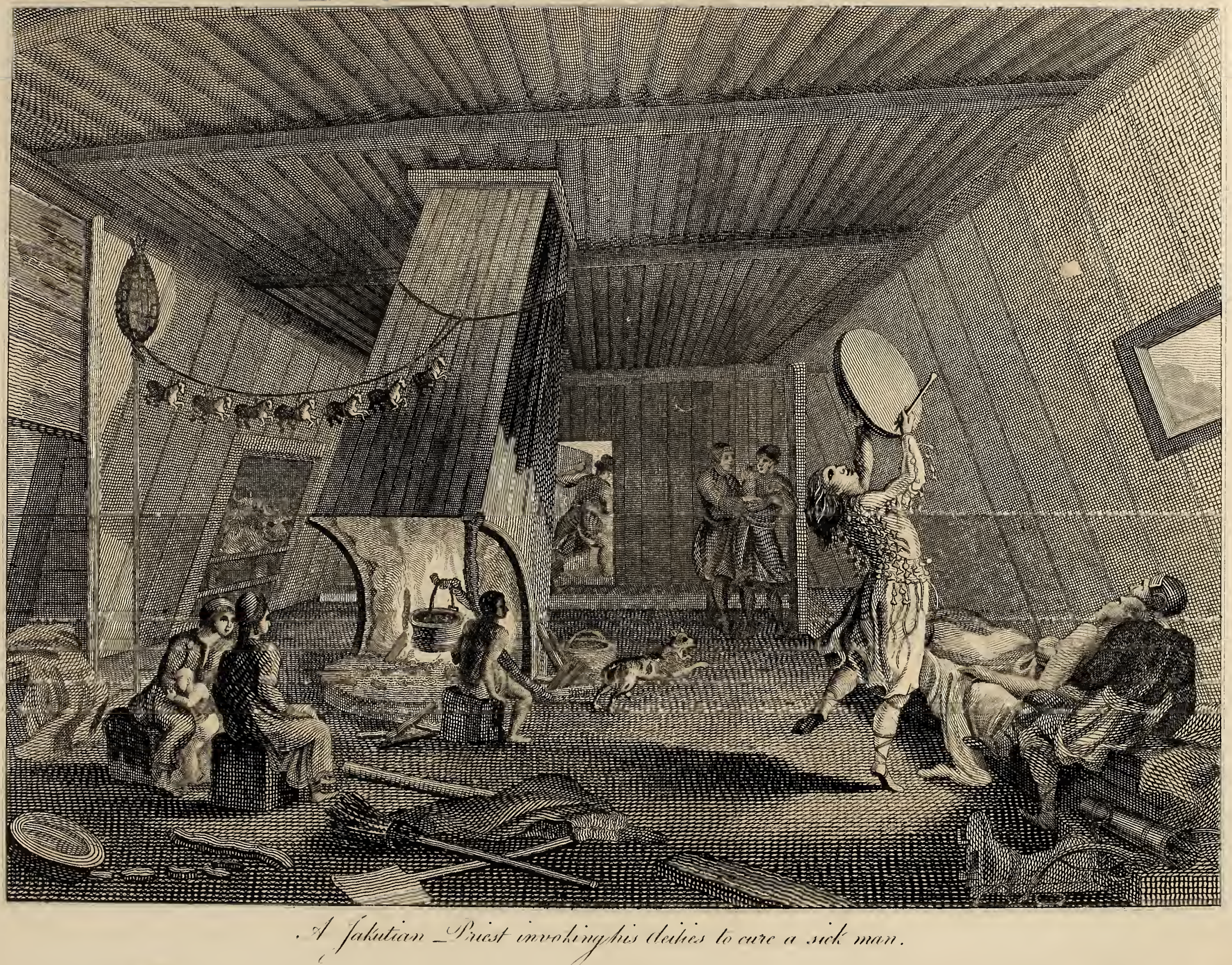





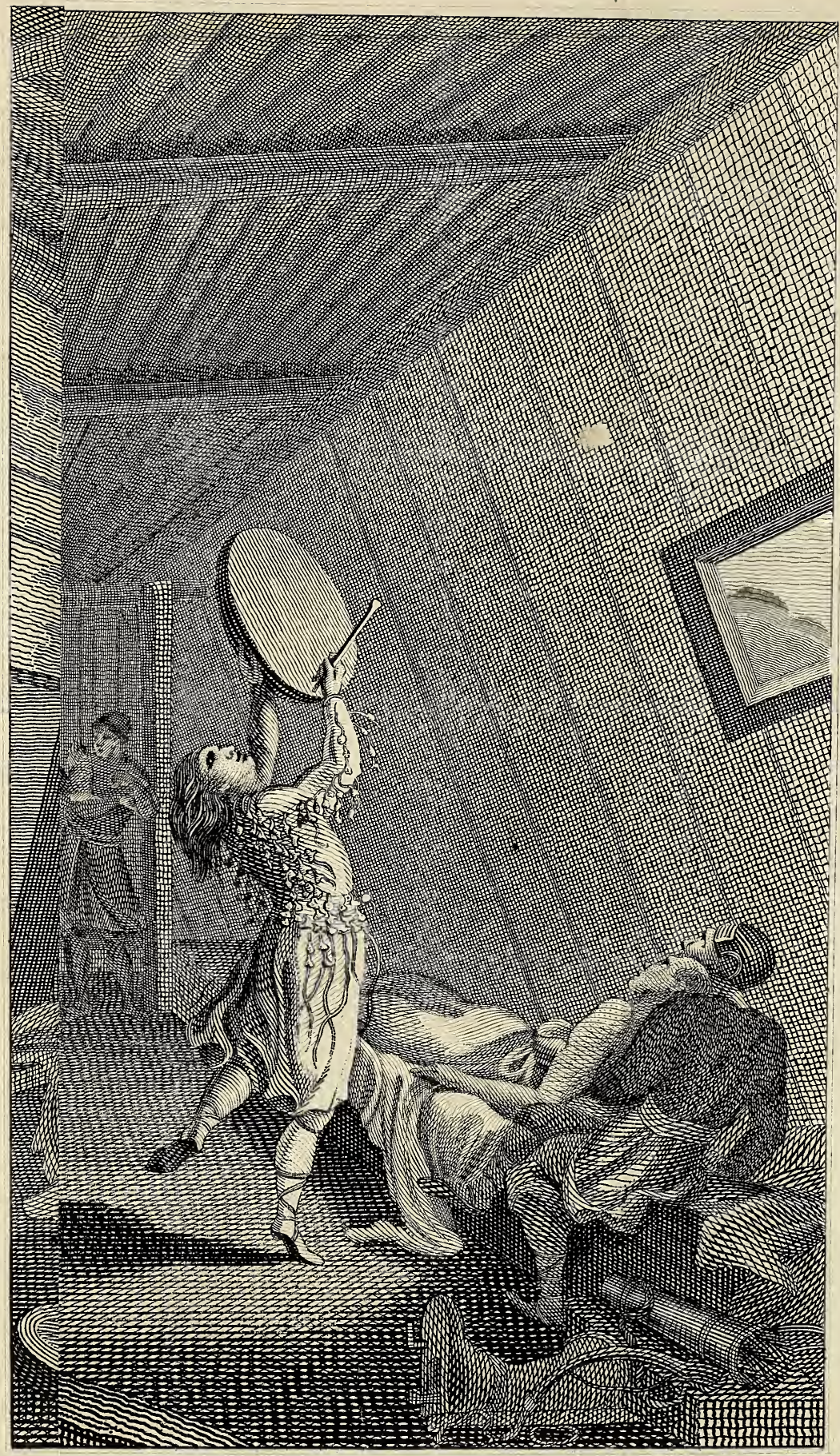

crue a sick man. 
guses in the mountainous countries, who wander about wit's their jurts and their reindeer.

In the mean time, I had an opportunity of witnessing tile incantations of a Jakitish shaman. He was invited by a sick person to appease the evil spirit supposed to have sent the disorder. The shaman exchanged his usual Jakutish dress for the habit of his office, made of reindeer leather (called Rudwuga), which reached not much above the knee, and was covered over with narrow thongs, and thin bits of iron of different shapes and sizes. Having made his arrangements, he untied his hair that was fastened together upon his head*, smoked a pipe of tobacco, took his taml trine, seated himself in the midst of the jurt, and beating it first at long intervals with his bolujach, or a flat stick covered with reindeer-skin, sung a shaman's song; in which, as my interpreter told me, he challenged all the seven spirits under his command. A ferw minutes afterwards he began to beat his tambourine again, and bawl with great veliemence, standing up and addressing himself in different positions; and then to jump and hop about the sick person to the sound of his instrument, at the same time screaming with a horrible voice, and distorting himself in a hideous manner. His head, with the dishevelled hair, rolled backward and forward with such rapidity that it seemed to be moved by springs; his eyes glared like those of a maniac; and falling soon after, from the violent exertion, inte a sort of swoon, two Jakuts used their endeavours to support him. Recovering in a few minutes, he called for a knife, with which he stabbed himself in the body, and commanded a Jakut to drive in the weapon to the hilt; then going to the hearth, he took out three burning coals, and swallowing them, danced without dis covering any symptoms of pain. At length he pulled the knife out of his body; and, after vomiting the coals with some difficulty, began to prophesy that the sick man would be better if he offered a horse to the wicked spirit which tormented him; at the same time defining the colour of the horse to be sacrificed. In all such cases, the lot, of course, always falls upon the fattest and choicest.

The shamans demand nothing for their trouble, but are contented with what is given them : they have, however, always the privilege of the first seat at the feast on the sacrifice, when they eat with a voracious appetite. For the evil spirit they set apart the head, legs, tail, and skin; which, when stretched upon a pole, are hung on a birch, or larch-tree, from whence they are never removed.

* The shamans only let their hair grow, the other Jakuts curting their's off, after the maniner of the Russian peasantry. 
The credit which the shamans enjoy with all these people, prevents them from being suspected of any deception; and the conceit of their holding an intercourse with evil spirits, confirms every one still more in the opinion, that whatever happens through the shaman is effected in a supernatural way by the aid of devils. This prejudice of conrse affords them an opportunity of imposing several tales and absurdities upon the superstitious ignorance of the multitude; such as pretending to have the power of knowing the past, present, and future; of commanding the winds and storms; of producing fine or bad weather; of findang things that are lost; of healing the sick, affording good sport to the hunter, \&c. and all which they never neglect to turn to their own adrantage.

\section{CHAP. II.}

DEPARTURE FOR U:HOTSK ON REINDERRS.THE TUNGUSES.-THEIR JURTS AND MANNER OF LIVING.-ARRIVAL AT OCHOTSK.-REMARKS ON THE TOWN, ITS TRADE AND INIIABITANTS.-THE FISIERY, AND DITFERENT SORTS OF FISII,-FOWLING.-BIRDS OF DIFEERENT KINDS。

\section{TrT}

1 HE messenger returned in twelve days, bringing with him twenty-five reindeer, a jurt, and two Tungusish families, with which I pursued my journey from Omekon on the 11th of March.

Some of the reindeer were employed for carrying our provisions and clothing, and others were saddled for our use. It was some time before I could accustom myself to this mode of riding, without real inconvenience, the saddle having neither girths nor stirrups, and its smallness scarcely allowing me a firm seat. It rested on the shoulders of the reindeer, and was only tied by a single slight thong, so that with the smallest loss of balance I must inevitably have fallen. Another little thong slung round the neck of the creature served as a bridle.

The first day we went 30 versts. In the commencement the road lead us over meadows, and afterwards through a woody vale surrounded with mountains. We took up our abode for the night on a mountain, abounding in moss, the favourite diet of the reindeer, where the jurt was erected. The Tunguse men having sut the poles for the jurt, and lighted the fire, the remainder vas done by the women, who unloaded the reindeer, unpacked the baggage, and fixed up the jurt. 'These people carry about with them all the materials for such a shelter; such as the rowdugen, the pieces of bark sowed together for a co- 


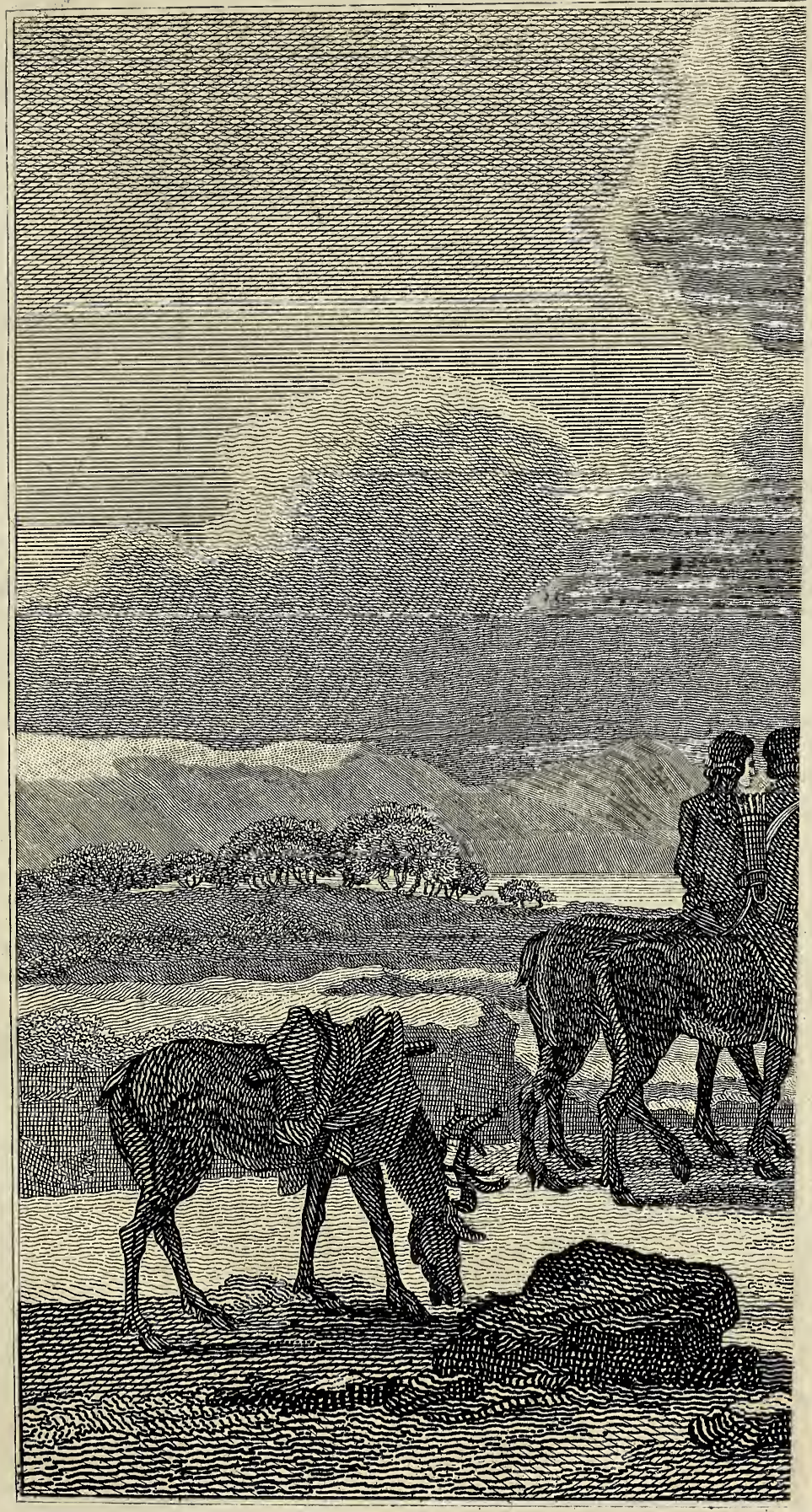

$$
\text { - Tringusiane cherin Dece }
$$





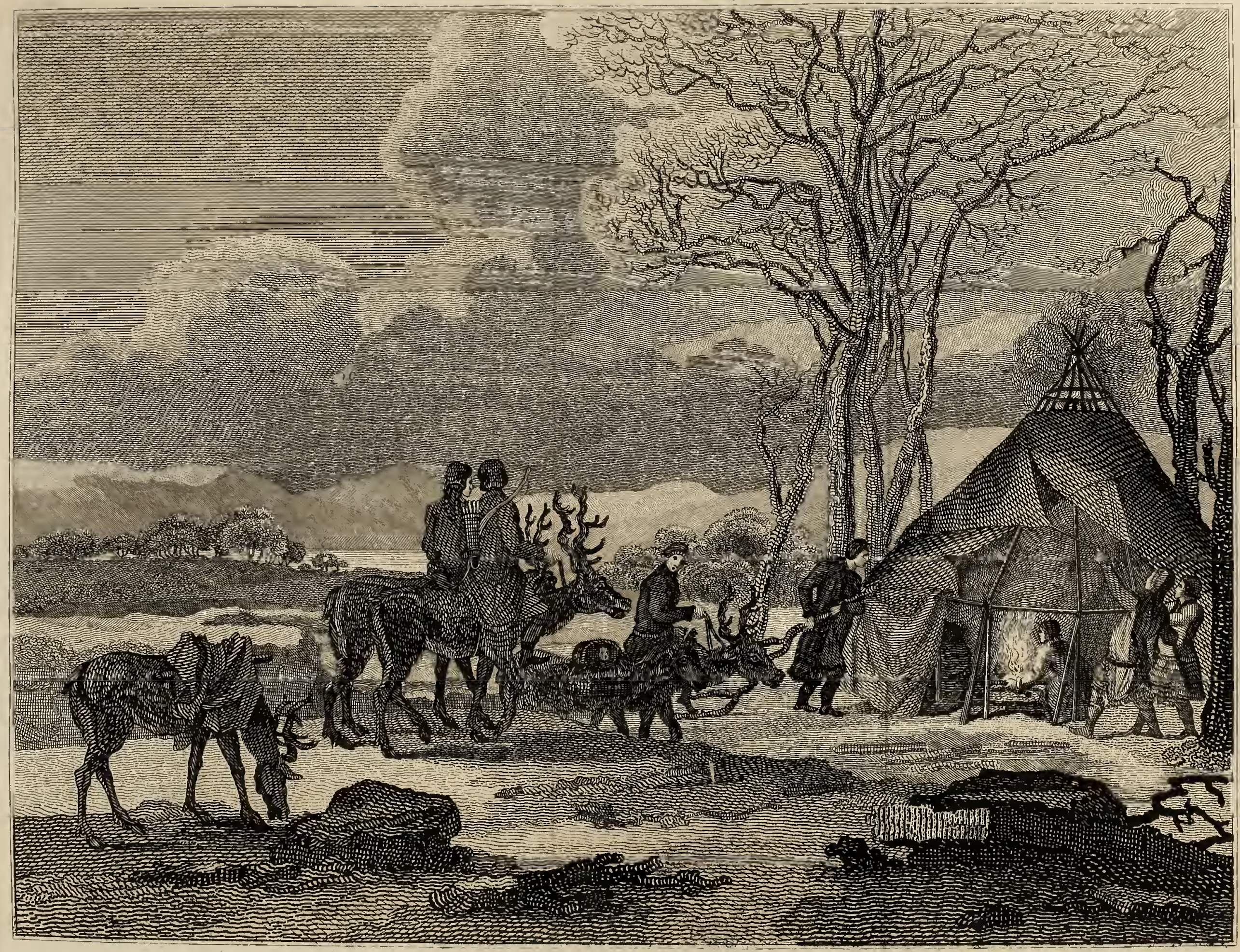

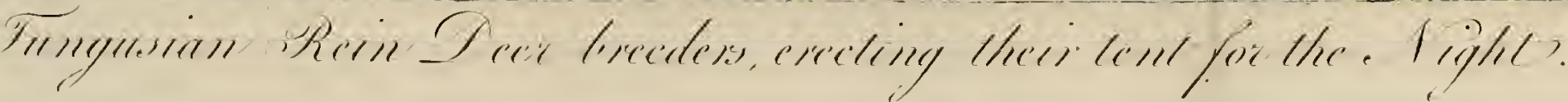



vering, the rings in which the poles are fastened, and the curtains used in the place of doors.

These jurts are commonly round, like those of the Calınucks, and conical towards the top, with an opening to give vent to the smoke; which, however, seldom ascends, particularly in severe weather, owing to the fire being made in the centre. The following days we pursued our journey over mountains, woods, and tundern $*$, by a rout known only to the Tunguses. On coming up to the tracks of some reindeer, our guides immediately informed us that their countrymen were not a day's distance from us; which proved to be accurate, as we overtook them in the evening at the place where they had encamped for the night. These people are all very clever in ascertaining, from the appearance of the reindeer tracks, both in winter and summer, not only the number of animals that have passed, but the length of time that has elapsed since the tracks were made. The next day they exchanged reindeer with us, giving us fresh ones in the place of our own, that were already jaded.

After some days we reached a spot on the river Ochota, called, by the Tunguses, Uega; where they assemble from all quarters, once a year, and hold a fair. Here the inhabitants of the towns meet the mountaineers, and barter their tobacco, knives, pins, trinkets, and cloths, for reindeer skins and dried meat or fish. "The former would be considerable gainers by this exchange, if, instead of throwing away their profits upon spirits, they carried home their merchandizes, and disposed of them at a good market.

The Tunguses are an itinerant people; throughout the whole year incessantly moving with their houses, family, and property, from place to place. Nothing but want, rain, or trade, can detain them a whole week in one spot; but they regard even this restraint as a great punishment. Their reindeer carry the effects, consisting of their clothes, jurt, and eatables; but they never load them with a greater weight than 60 pounds. Infants unable to ride are put in pannels, lined with moss on one side, having an equal weight on the other to preserve the balance. They resemble the Jakuts in their method of pacifying a crying infant, by giving it a piece of fat to suck. The men and women ride, leading the beasts of burden. The riches of the Tunguses consist altogether of reindeer, some of them having upwards of 2000 , which usually graze in mossy places, and in great herds; but whatever may be the extent of their possessions, they are very loth to slaughter any of them for

* Tundern imply marshy, boggy countries, covered only with moss and a few small bushes, 
food, miless they be any way damaged; they even prefor to ondiure hunger for many days, or content themselves with the bark of trees, or, old shrivelled skin, which they constantly carry about with them, to serve in case of exigency. They eat up every part of the animal which they kill, not throwing away even the impurities of the bowels, with which they make a sort of black puddings, by a mixture of blood and fat! 'They eat no raw meat, even when dried, but they are fond of the raw marrow from the bones, which having tasted myself, I did not find offensive.

On the 25th of March, our reindeer carried us to Arka; a place so called from the river of that name running into the Ochota. Here we found some pedestrian Tunguses, who go on foot in summer for want of reindeer. In the winter they harness dogs to their nartes, and build their jurts under ground ; but in other respects do not differ from the other tribes of their nation.

At this place, 1 exchanged my reindeer for the dogs and the nartes. These are light sledges, about twelve feet long and two broad, and a foot and half high from the bottom. They are of so slight a structure that they may be conveyed by hand. Ten or twelve dogs are harnessed to them by neans of small cords, with a large rein between, serving as a pole. The foremost couple are used to turn right or left at a word; but when the driver wishes to stop the narte he fixes his oschtol in the now, through the sledge.

The oschtol is a thick staff tipped with iron, and having a rattle at one end, by which the pace of the dogs is quickened. Towards the spring this mode of travelling becomes excessively. incommodious, for the nartes having no indented seats, and the road being often uneven and steep, it is not unfrequent for the traveller to be thrown over, and sometimes pitched on the stumps of trees, or other hard substances; particularly when the dogs get scent of an animal, and become ungovemable. In pursuit of an otter, for example, they are not to be restrained from going into the water, and dragging their nartes after them; so that if the driver be not dexterous enough either to tum over the conveyance, or to jump out, his life is in great danger.

Whenever there is a great fall of snow, or it be driven into unusually large heaps, then two or three persons are obliged to go before to make a track, and mark the road, by the position of the trees, mountains, and rivers: the snow, thus trodden, will be sufficiently firm to bear any weight until the return of warm weather.

On the 27th of March I arrived at Ochotsk, situated on the shore of the sea called by its name, close by the mouth and 


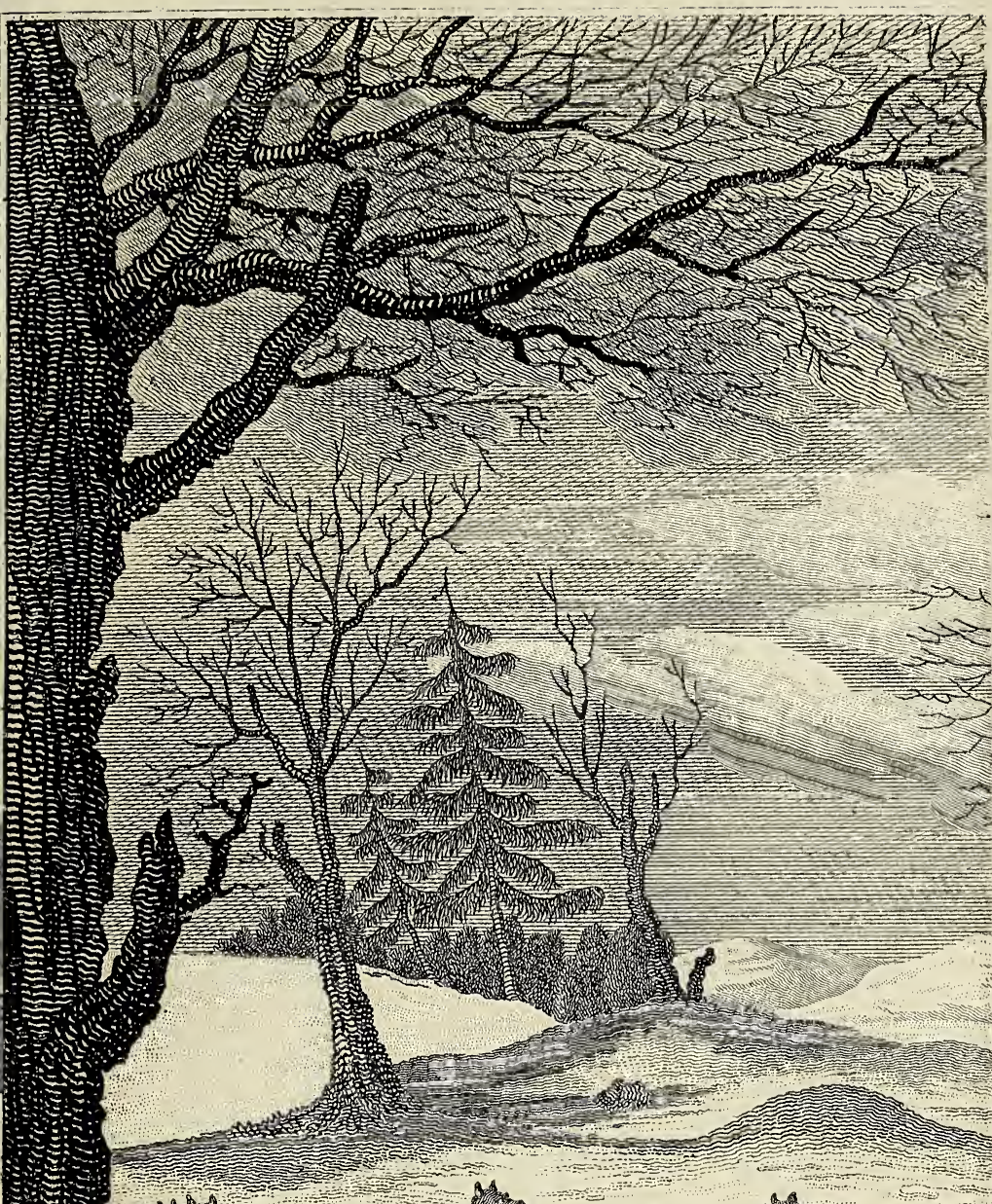

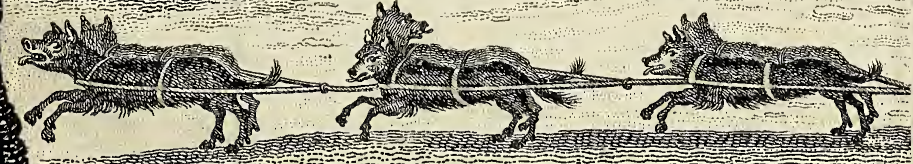
(1) (1) (1) (1)

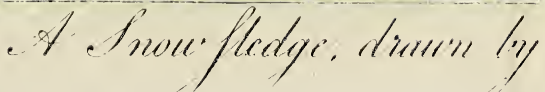





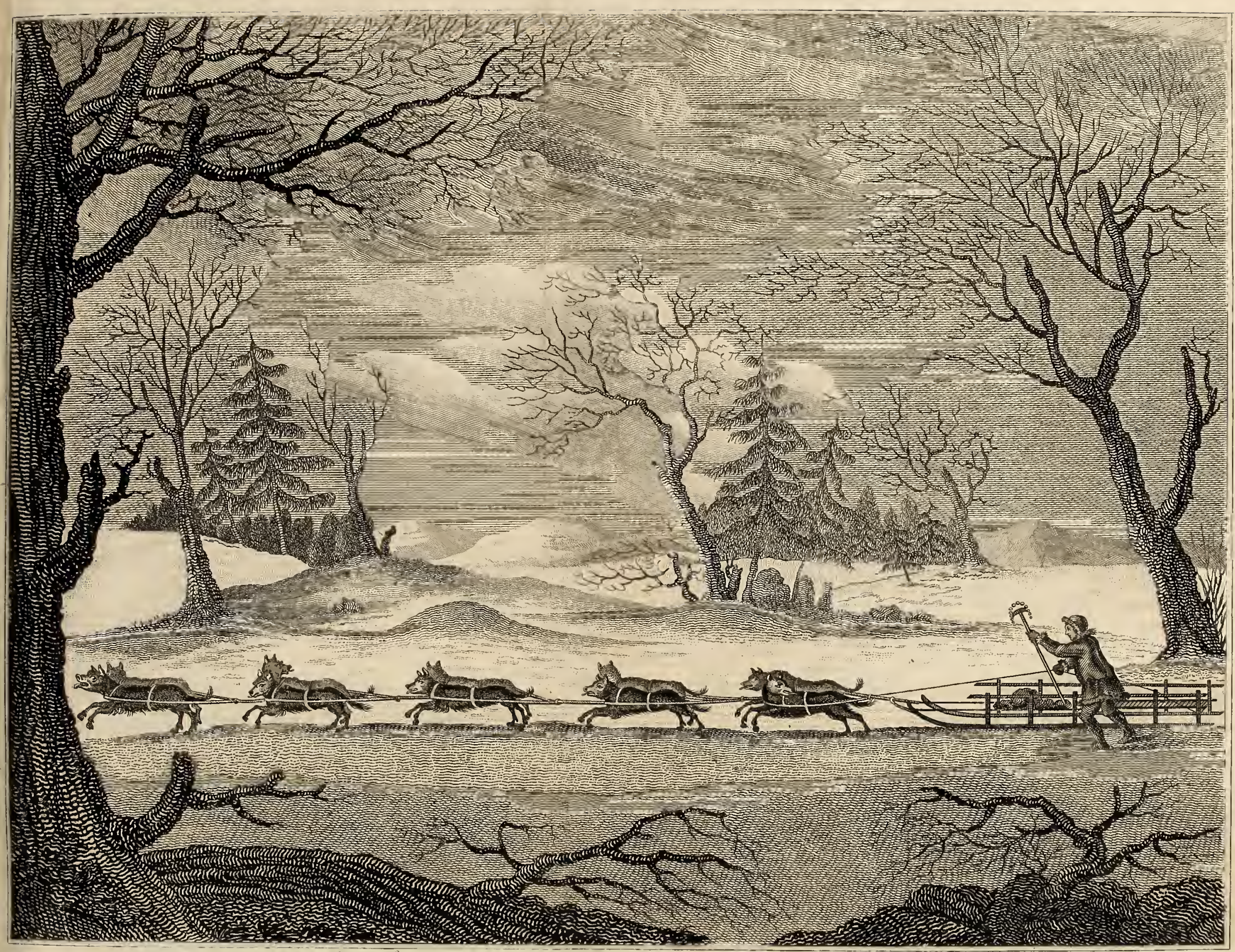

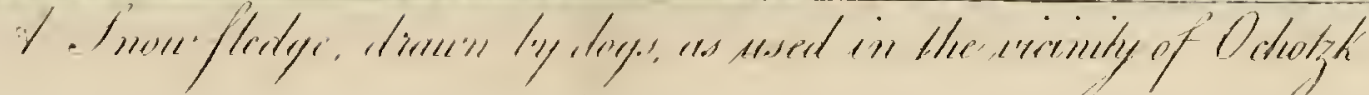



conflux of the two rivers Ochota and Kuchtui. The Ochota washes its sandy gravelly beach every smmer with vehemence, carrying away whole houses with it yearly; so that the town has already lost three streets within a short time; while, on the other hand, the beach receives an amual accession from the stones driven to it by the storms. The government having, therefore, resolved on transplanting the town to a safer situation, no new houses are now erected, and the old ones, which were built upon the establishment of the place, are falling to decay. Ochotsk has a wooden church, a palisadoed fortress, and some magazines. The inhabitants consist mostly of persons in military and civil capacities : the latter of whom principally belong to the lately established judicature in the stadtholdership of Irkutsk. On this establishment, Ochotsk became a eapital, comprehending the peninsulas of Kamtschatka, the Aleutian and Kurilian islands, and the whole coast from Ochotsk to the Tschukatish cape, within its jurisdiction.

The trade of this place is carried on chiefly by merchants from other towns, who bring provisions and other merchandizes, of European or Asiatic manufacture, for the Russians, Tunguses, Jakuts, Kosaks, and Tschukatians; all of whom, except the first, make their payments in skins. There are also trading companies, having their agents, who build small craft at Ochotsk or Kamstchatka, and dispatch them to the Aleutian islands, and North America, for the purpose of collecting furs. The crew are hired from all parts of Russia, and the command of the whole is entrusted to an experienced trader, entitled peredowschtschik, or forerunner, who has been on two or three such expeditions before. Besides this, the government provides a mate and steersman to conduct the vessel. Their voyages frequently last ten years, and on their return, the produce is divided into certain portions, called pai.

Having made the object of my mission known to the commander, I commenced my examination of the vessels, stores, and building materials; but found every thing so shattered and decayed as to be totally unfit for use. In my rambles among the woods, I was not much more successful, having found, within the compass of above 100 wersts, but few trees sufficiently large for building our vessels. Nothing could exceed the toilsomeness of this research, although it was considerably relieved by the kindness of my worthy friend, the collegiate assessor Koch, who accompanied me purely from the desire of aiding me with his knowledge. We set off in the beginning of April, and were obliged to go 70 wersts in snow-shoes. Of these there are two sorts; those which are broad and covered underneath with reindeer skin, for the soft snow; and the others, SARYTSCHEW.] 
long, narrow. and plain, for the hard snow. From our inex. perience in this mode of travelling, we often sprained our ancles, got entangled in the shrubs, or fell into heaps of snow so very deep, that neither of us could have been saved without the assistance of our attendants.

After my return, my first concern was to procure men to fetch the wood; but in this respect the commander was unable to afford me any great assistance; the few men he gave me being so afflicted with the scurvy that they could scarcely walk, much less do any labour. The poorer classes here are very subject to this disorder, owing partly to the damp and cold weather, and partly to their diet, which consists of salt fish and a sour liquid, called burduck. Meat and fresh fish are scarcely to be procured for money; every other kind of provision is to be purchased only at an immoderate price, a pound of butter costing three shillings; the same quantity of flower one shilling; oatmeal ninepence, and other things in proportion. People in any tolerable situation usually lay in their stock for the year at the summer fair, or procure it from Irkutsk; and those who cannot afford to do this must submit to all the hardships of want and bad food. On my arrival here, I might have experienced a similar fate if I had not met with so friendly a reception from the principal persons of the place, who not only invited me to their tables, bue exerted their utmost to lessen the difficulties $I$ had to encounter.

At the close of April, the Ochota was cleared from the ice; and the water swelling to an astonishing height, occupied all the lowlands with rapidity, but returned to its boundaries again in the space of ten days, when several sorts of fish, such as malmes*, kunsches, and kambales, began to make their appearance; which were succeeded by shoals" of smelts and herrings, and afterwards by sturgeon and sea-calves. My people now beginning to collect strength from the return of spring and fresh fish, I sent them otit after timber, a great quantity of which they felled for me in the summer months.

* The names of keta and malma are no where to be found, but the others are described as follows in the dictionary of the Russian Academy:Kunsha, Salmo Cundsha, a sort of salmon. Its usual length is two fect; its tail forked; its scales silver-coloured, with a shade of blue on the side and white at the ends. It is found in the bay of the Northem Ocean, and the White Sea. Kambala Pleuronectes. Under this appellation is comprehended many sorts of scaleless fish, with cyes on each side their longish round bodies.- Narka Salmo is a species of salmon about a yard long, and the fifth of a yard broad, with a red body, small head, five small reddish teeth on both sides, blue tongue, yet white on the side, a bluish back, with dark spots, and the tail a little arched. Its scales are large and reund, and come off the skin very easily. 'They collect in great shouls in the river from the eastem and Penschinkisch seas. 
At the commencement of June, the abovementioned fish disappcar, and give place to other sorts, as the keta and the narka, in size and appearance somewhat resembling the salmon, only that the narka has a much redder and firmer Hesh; their taste is very pleasant, and in July they are in full season. In August and September, they come in such quantities as to change the quality of the water. The inhabitants at these times lay in a store for the year, both for their own use and that of their dogs, of which each person has one or two team, consisting of 12 or 24 . These dogs differ in very few respects from those in Russia, except by baiking less and howling more, which they frequently do, particularly towards the dawn of day; one takes the lead and is followed by all the rest in the town, which forms a concert of no very agreeable kind.

The fish are cured in various ways. The narka are stretched out and smoked in a chamber, peculiarly adapted for the purpose, then laid in a box and strewed with dried and powdered keta, which is said to be a good preservative. They are thus sent sometimes to Irkutsk and Jakutsk, but not in great quantities, on account of the difficulty or expence of the carriage. The keta are dricd in the sun, the fat in the back-bone having first been taken out, in which state they are called jukol. The inferior of both kinds are given to the dogs. They are also salted in great tubs, either whole, or the spawn alone. Salt is here extracted during the summer from the sea-water, in an office belonging to the crown, situated about twelve versts from the town. At the close of autumn and commencement of September, when the fish are at their full size, they are caught without difficulty, being taken with the hand out of the sea, and thrown into pits fitted for the purpose, where they turn sour, corrupt, and dissolve. These are intended for the dogs in general, but are sometimes eaten by human beings. The Kamstchadales, for example, esteem it the best and most delicious of all victuals, although the smell is so strong as to extend many versts distance from a pit newly opened. At the close of September, or the commencement of the frost, the keta, and another fish which comes at that time, called lomki, are left to freeze, and thus preserved in heaps for the winter.

The nets used for fishing are either smaller or larger according to the size of the fish to be caught. The larger nets are thrown out from the shore on long poles. In the fishing season they fill so rapidly that it is scarcely possible to draw them in quick enough to prevent their being overloaded. The Kosaks in particular, with their wives, attend to the nets at this time, indulging their appetites continually with the cartilage of the ishlies' heads, which they regard as a great luxury. The dogs 
have probably acquired from them the same propensity, for during the season of plenty they go to the water's side in search of fish for themselves, and eat the heads only of whatever they catch.

Birds of passage are very numerous here in spring and autumn. At the close of April and May geese and storks resort to the meadows in immense flocks, and the bays are covered with ducks of every description. In June they leave these parts, and are succeeded by snipes; but in July and August there is no other bird to be seen except sea-ducks, called turpane, which assemble here in vast quantities. This being their time of moulting, they are unable to fly, and fall an easy prey to the inhabitants, who surround them in their canoes*, and driving them into shallow parts of the water, jump in, and either kill or catch them alive in their hands. They then string them by means of an iron or bone skewer, on a long cord that hangs at their backs, which frequently affords an opportunity for those following to practise a theft on their neighbours, while eager in the pursuit, by cutting off their ducks and stringing them to their owu.

The Tunguses have a mode of catching these birds by means of an artificial hen-duck, which, when stuck on a long pole, tipped with a sharp iron, and presented to the males, attracts them all towards it, and brings them within the reach of the fowlers. In lakes and standing waters, the ducks are likewise caught by snares, two different ways. They have a method of confining the creatures within a certain space by means of twigs, leaving openings only where the snares are fixed, by which the ducks are caught when they attempt to get ont. By another method, they decoy the ducks with the spawn of fish into snares that are concealed under water.

Among the birds which frequent the forests and fields, are white-tailed eagles, woodcocks, and partridges. In the winter there is a remarkable bird called a water-sparrow, which makes its appearance on the open banks of the river. It is the size of a thrush, and has a black plumage: but although there is no web on its feet, it often dives, and continues some minutes under the water; yet it has not been observed to swim on the surface. There are no common sparrows here; and the crows are perfectly black. The mews are of five different sorts; namely, the +semisashemjaa, the grey and white spotted, the $\$$ goworuschka, the $\|$ mortyschka, and the of rasboinika. The first is

This canoe is called odnoderewka, probably from its being constructed out of one tree only.

+ Sémisashennaja, from scm, seven, and sashena, fathom._-_ Goworuska priter, from godorit, to speak.-.-I Mortyschlica sterna, or seaswallow. - T Rasboinika, a plunderer. 
unusually large; its outstretched wings, with the feet and head, comprehending an extent of 7 fathoms; and is so ravenous as to eat till it cannot move. The grey with white spots, are like ours in Europe, and resemble the goworuschka, except that they are rather smaller. The latter derive their name from sitting on the water and continnally screaming. Mortyschka, the smallest kind, has short red feet, and a forked tail. 'The last description are black, of a middle size, with two long feathers in their tails. They never catch tish themselves, but plunder them from others; from which circumstance they have received their appellation.

CHAP III.

2IR. FIILING'S ARRIVAL AT OCHOTSK.-MY FARTHER JOURNEY.-DANCE OF THE FOOT TUNGUSES.-ON THE INSTINCT OF THE IISH.-THE DOCTOR'S ASSISTANT LOSES HIS WAY. - DIFFICULTIES ON THE ROAD.-ARRIVAL AT THE FORTRESS OF WERCHNE-KOLYMSK.-JUKAGIRCANS.-THEIR MODE OF LIVING.-UNEXPECTED TIRE.

Mr.

R. Billing, our commander, arriving at Ochotsk, in July, with the remainder of the expedition, I was again dispatched to the fortress of Werchne-Kolymsi, and being provided with some attendants and a hundred of the best horses just come from Irkutsk, I set off on the 1st of Angust.

Our road, for the first 75 versts, to the village of Mundakan, was very good, with the exception of occasional floods, through which we were obliged to wade. It afforded us every where fine prospects. The woods consisted principally of larch-trees, here and there intermixed with beeches and alders. The ishands scattered along the rivers are covered with willows, poplars, and pines; the leaves of which latter trees afierd a very delightful aromatic odour. The road itself is often lined with eglantine and shimolost, which yields sweet berries that are in great esteem here. The shimolost, or Lonicera xviosteam, is a shrnb, not exceeding a fathom in height, having a grey smooth bark and spiral leaves. Two white blossoms grow on each stem. The fruit is an orbicular, succulent, red berry, having four small stones, and is the favourite diet of many birds. The wood is used for ram-rods, pipe-tubes, \&c. The Tartarian shimolost is a finer species of this kind, which grows much higher, and has smoth leaves in the form of a heart; its double blossom is of a pale flesh colour, and its berries of a pale orange colour. It is a native of Siberia, and is literally a species of wild cherry. Bilberries and knaesheniza are likewise to be found in some 
parts ; the latter resembling the wild strawberry both in appearance and leaf; but its blossom is rose-coloured. The berries have a very agreeable perfume and fine flavour. It is the pleaeantest fruit growing in the northern countries, and is abundant in Sweden, Russia, Siberia, and Canada. From the blossom and leaves the inhabitants make both tea and a decoction, which is in high estimation for pectoral complaints. The richmesss and verdure of the meadows, every where overspread with luxuriant grass, might be supposed to denote a prolific soil, and yet the repeated experience of the government evinces that it is unfit for the production of grain. 'This is, perhaps, less atiributable to the soil itself than to the shortness of the summer and the depth of the snow, which continues on the ground, in some places, until June. The weather is cold and damp the greater part of the year, and not unfrequently so in that season when lieat is indispensible for bringing the corn to maturity. For this reason, the vegetables and garden fruits are far inferior to those in other places lying nearer to the north pole, where, as in Archangel for example, they have a better climate. The cabbage here has no stem whatever, but shoots forth in leaves only. Potatoes, turnips, and radishes, grow but to a very insignificant size.

Our road continued dry and agreeable twenty versts beyond Mundakan, after which we had to pass through marshes and mountains. The moss of these marshes is so entangled with the roots of the trees as to form a tolerably firm, but yet movable ground, which yields to the tread of the horse. Sometimes the traveller sinks in, and requires the assistance, of all his companions to help him out; but in such cases it is easy to find a safer way. These treacherous spots are termed baidaranen. The moroschka, a fruit peculiar to marshes, is found in great abundance here, particularly in brooks and vallies, which produce also some bilberries. The berries of the moroschia, Rubuschumomorus, are of a yellowish colour, the size of a cherry, and of a semicular form, composed of many small triangular grains, lying together in double rows. Its pulp is very succulent, inclosed in a thin brittle husk.

After a journey of six days, we arrived at Arka, a place belonging to the pedestrian Tinguses, lying about a hundred versts from Ochotsk, at the mouth of a tolerably large river of the same name, which runs into the Ochota. Our commander overtook us this day with all his attendants, except the boatswain, who had fallen from his horse in crossing a piece of water, and was drowned. We found the inhabitants fishing for the lieta, which was very abundant here in this season. 'The shallowness andclearness of the water afforded them the adrantage of distin- 
guishing the fattest fish, which they strike so dexterously with their spikes as never to miss their aim. This spike, in Russian bagor, is an instrument particularly in use among the Kosaks on the Ural, and at the fishing of the Wolga, consisting of an iron spike, with two points, fastened in a long stick.

After supper our landlords gave us a dance, in which men and women forming a circle, jumped to a tune that consisted of the two words ochur, juchur, continually repeated. However wretched the condition of these people may apparently be, they are incomparably more happy than many of the cultivated sons of fortune, who riot in uninterrupted luxury. To variety and care they are alike strangers. Their wants are extremely limited; an abundance of fish is the height of their happiness, as it constitutes their principal subsistence. They barter it likewise with their reindeer Tunguses for their clothing.

We now pursued our course all together, passing over a diversity of mountains, and through numerous rivers. The weather, which had hitherto been favourable, changed to rain on the 9th, that continued for twenty-four hours without intermission. In addition to which, our guides were now unable to conduct us farther. We fortunately met with some other Tunguses, four of whom we engaged, with twenty-two reincieer. From the river Uega, where we had just been stopping, the road became insupportably tedious, leading perpetually through mountainous and marshy countries, and sometimes being totally blocked up by the trees which had been only half consumed in a conflagration*. Our horses suffered so seriously from the fatigue, that we were obliged to leave many of them in the wood; and meeting soon after with a convenient place for a night's lodging, which yielded good fodder, we resolved on resting the following day in this place.

We spent this day in shooting and fishing, and caught many of the chariust in our nets; among which was a narka, in a perfect

* In the country around Petersburgh it is not unfrequent for extersive woods to be consumed. The fire commonly arises from the negligence of the peasantry coming in bodies to the city, whose fires, towards the evening, afford an agreeable prospect.

+ Charius, salmo thymallus, a species of salmon; its head is rather small, obtusc, and spotted hlack, the under part and the sides having a bluish cast; its gills are furnished with two rows of teeth, extended into its throat. Its body is covered with a thick firm scale, its back dark green and rather arehed, its sides flattened and of a grey bluish colour. From the head to the tail a bluish stripe runs down on every scale, the middle of which is spotted black. The belly is white, the pectoral fins small and yellowish ; those on the side, tail, and belly, reddish; that on its back large, yellowish in the begiming and reddish at the ends, having four rows of round spots. The charius frequents the rapidly flowing springs of the mountains, and is two feet long. Its flesh is white, firm, delicate, and fat. 
state of transformation, having scarcely a single mark of similarity with its kind remaining. Deep red and dark blue spots supplied the place of scales; its gills were quite bent; its teeth grown out long; its body become pulpy snd spungy, and on its back it had an excrescence. It had probably strayed into this lake through a brook communicating with the Ochota, notwithstanding the velocity with which it rushed down the mountain. In fact, the keta and narka appear to be impelled by a particular instinct towards the rivers; for they continually force themselves up in spite of every obstacle, and when disabled, from loss of strength, to proceed any farther, they generally perish and moulder away on the shore: few, therefore, ever return to the sea. We should naturally suppose, from the prodigious number of narka and keta continually passing every year from the sea into the rivers, that these species of fish would soon become extinct; but the contrary being the case, we are led to the conclusion, that the spawn of the dead fish is carried back into the sea, and there brought to perfection.

On the 15th, our commander went forward, taking with him the doctor, two chasseurs, and some Tunguses as guides. The second day after the doctor's departure, his assistant, Mr. Main, an Lnglishman, staying behind to collect stones, missed his way: we did not perceive his absence until the time of our encampment for the night ; and were, therefore, obliged the next day to retrace our steps in search of him, when we found him in the afternoon in a wood. His horse having run aivay, he had missed his road in pursuing him, and not knowing what step to take, resolved on returning to the first Tungusish dwelling: which would, however, have been scarcely practicable, there being no such dwelling within the distance of 100 versts.

After following the course of the Ochota for the distance of 400 versts, we at length turned off to the right, and reached the source of the river Kuidussun; the shallow parts of which are occupied with masses of ice four feet in height, that appear never to be dissolved*. Here we had the misfortune to lose our 'Tungusish guide, who absconded with several of the reindeer, and brought us into the most unpleasant dilemma. We were totally unacquainted with the way forward, and had no other alternative than to follow the steps of Captain Billing, whenever we could trace them, which was, unfortunately, but seldom the case, the road generally leading over moss-grown places, and every Tunguse taking the direction which struck him to be the best. By the exercise of our judgment and patience, we,

* This ice is probably accumulated by the water spouting forth from the springs of the river. 


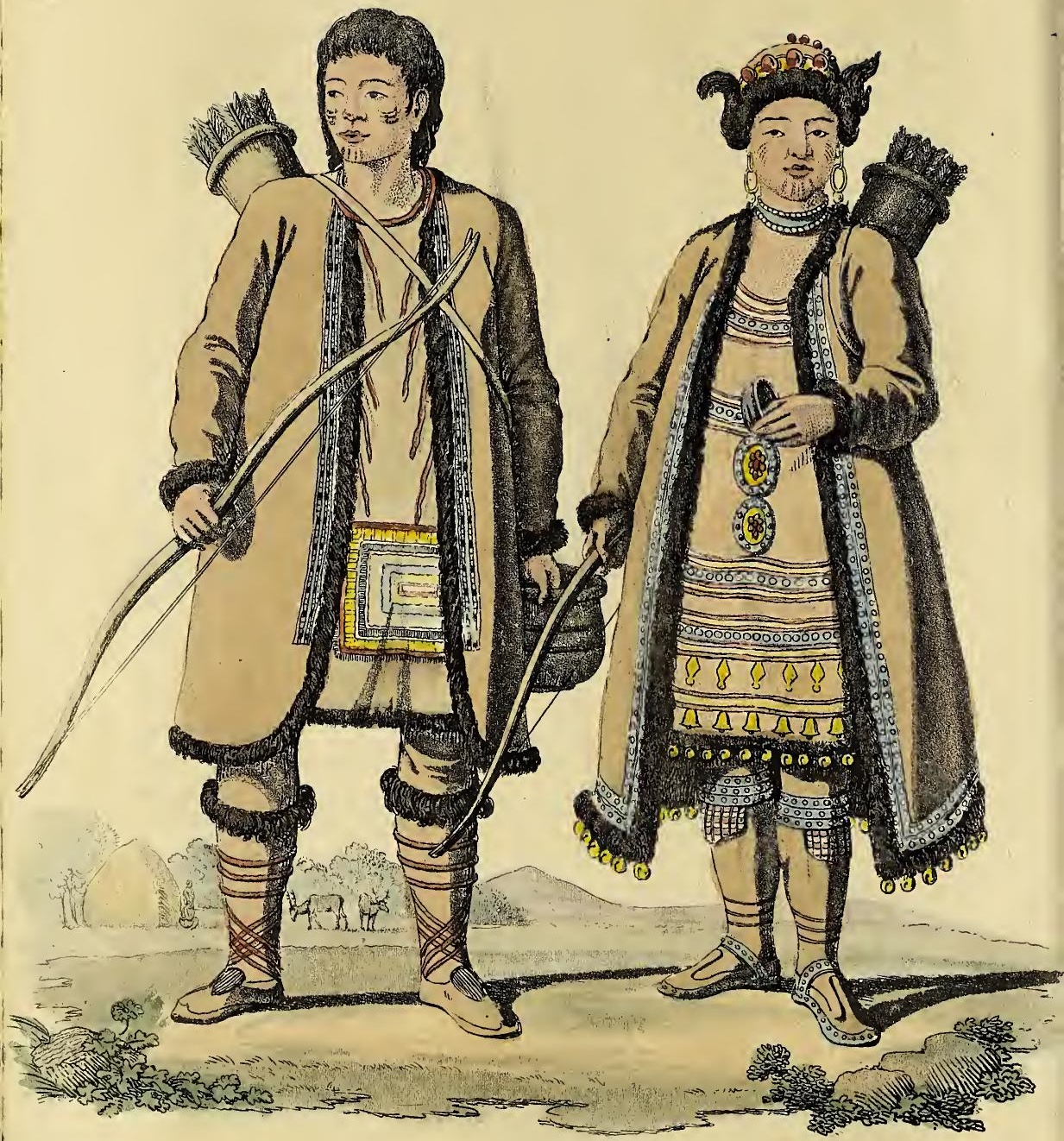

H. Han \& Hoinan among the Tunqusian Rhein deer Ireeders in their Summer drefses. 
however, succeeded, after a tormenting search for 60 versts, in finding a Jakutish track over meadows, that promised to bring us to an inhabited spot: but in this we were disappointed; for after a journey of 18 versts farther we came to some empty Jakutish jurts, from whence the road took five different directions. I dispatched some of my people in several directions, and obtained the next morning; to my no small satisfaction, a Jakut, who offered to conduct us to the jurts of the Jakutish knask. He fulfilled his promise, and carried us in nine days to the desired spot, where we found Captain Billings waiting for us. Here we were obliged to stop five days for fresh horses, which were to be collected from the distant jurts.

On the 29th, we pursued our journey in two distinct parties; Captain Billings proceeding forwards with one sailor and three chasseurs. The first day we waded through the river Omekon, and passed along two other rivers, until we reached the Atschugui-taryn-urach, or little icy.stream, which is so called from its being continually covered with ice of an almost incredible thickness. Sixty versts farther, after wading through the Ulachan-taryn-urach, or large icy river, we had to ascend two high mountains, about a verst distant from each other. The former is covered with small larches, moss, and cedar shrubs, which do not rise above two fathoms in height, and yield fruit but every other year. The latter, which is higher than any in that quarter, extending from south-east to north-rrest, is covered only half way up with moss, the rest consisting of naked rock. We effected our ascent and descent with the utmost dificulty, being obliged, from its exceeding steepness, to creep rather than walk, for fear of rolling down. The horses, though very tame and accustomed to such roads, were not all able to keep their feet. Our course then led us alternately over beautiful meadows and large rivers, or through wondy and mountainous countries. The Tunguses usually repair in the summer to the open summits of these mountains to catch the wild sheep which frequent those parts, or to graze their reindeer, which are here less tormented by the insects than in the forests.

Our guides being unable to conduct us farther, I was obliged to wait some few versts distance from Werchno-kolymsk, until a suitable person could arrive from the neighbouring Jakutish jurts, called Kyssyl Balyktach, after the name of a peculiar fish, which is caught by the inhabitants in their lake. The fatigues of the journey were rather increased than diminished towards the close. The roads, which were either sandy or marshy, exhausted our horses to that degree, that we sometimes despaired of reacling the point of destination. On our arival we found Captain Billings and his attendants, but none of the SARYTSCHEW.] 
baggage, which had been left behind, owing to the badness of the roads. The greatest part of our horses being totally disabled, it was necessary to procure a fresh set for the purpose of fetching the luggage.

The fortress (Ostrog) of Werchna-kolymsk, is situated on the right bank of the river Jassachna, two versts distance from its conflux with the Kolyma. It consists of five peasants' huts, three jurts, and a separate court surrounded with a paling, in the middle of which is a black log-house (isba) and some granaries. In this narrow spot it was no easy natter to dispose of all our people. Our commander chose the best isba, whilst two of my companions and myself took up our lodging in a jurt. The greater part of the crew were obliged to reside in the woods until a shelter could be made for them, besides which it was necessary to build a forge and an oven for drying the biscuit.

In the mean time the felling and transportation of the timber for our vessels was commenced with vigour, although the passage of the river was rather impeded by the frost, which set in on the 27 th of September; yet as soon as it was frozen sufficiently firm to admit of any weight, we conveyed the wood over the ice by means of horses borrowed from a small body of Jakuts, who had lately settled in those parts at a distance from the fortress. These Jakuts bave but a small quantity of cattle, and subsist principally by fishing. In the winter they travel only with dogs, by which they are distinguished from the rest of their nation.

At the commencement of the frost, and previous to the closing of the river, the people were busy with their nets in catching a particular sort of fish called tschirai. Afterwards they made openings in the ice, in order to catch eelpouts; the largest of which weighed 25 pounds. The cold at this time, in the niddle of October, was 30 deg. Reaumur.

In this month, Mr. Billings and the doctor went a journey of 40 versts up the river, to a little place inhabited by some families of the Jukagirens. This was formerly a very rich tribe, who had kept their neighbours in awe, and possessed dominion over a vast extent of territory, until the greater part of them being swept away by the small-pox, and another contagious disorder, called here kilikinska, the Kosaks and Tunguses, their ancient enemies, gained the upper hand, and retaliated on them. by every act of oppression in fishing and hunting; which gave rise to a war that exterminated almost entirely the little residue of their people. The stragglers who had escaped this last ravage gought protection from the Russians, and took up their residence in the proxinity of the fortress. 'The close intercourse thus 
arising between the Jukagirens and the Kosaks gradually assimilated the customs and dress of the former to those of the latter. But previously to this, their way of living entirely resembled that of the Tunguses; having, like them, their reindeer and their jurts, with which they strolled from place to place. At present they live in hovels, and make use of dogs in lieu of reindeer, for their winter excursions. Their food consists of fish and the flesh of elks, which are very abundant in the islands and rivers; particularly of the river Korkodon, which flows into the Kolyma 200 versts distant from the fortress. Thither the Jukagirens usually repair in April with their dog-sledges to hunt not only elks, but also sables, foxes, reindeers, and every species of animals which afford fur. They pursue the elks in snow-shoes, and run them down, until they are so perfectly enfeebled as to fall an easy prey to the huntsman. In this pursuit the latter have every advantage; for the immensely deep suows and the NASTEN , so frequent in that season, which are no impediments to them or their dogs, cuntinually stop the creatures in their career, and combine with their natural unwieldiness to prevent their escape. They cut the flesh into long thin slices, and dry them in the air. As soon as the river is free from ice they swim on floats to the fortress, where a festivity and carousal commences anong the Kosaks, with whom they barter their spoil for the necessaries fetched from the town, but above all for tobacco, to which they are immoderately attached. This fair commonly lasts until the river, which has overflowed the country, returns to its bounds, when they separate and take various directions for the purpose of fishing.

Since their counexion with the Kosaks, the Jukagirens have made a profession of Christanity, blended, indeed, with their own superstitions; particularly the incantations of the Schamans. In this particular the Kosaks, who cannot boast of a much brighter illumination, have but too faithfully adopted their errors. They ascribe every sickness to witchcraft, and even imagine themselves sometimes to be under the influence of some evil spirit. For which reason they have a peculiar dread of one female Jakut, named Agraphenna Schiganska, a xhaman of great influence, who died thirty years ago. They fancy that she visits the people in order to torment them, and must therefore receive their homage and sacrifices. Active as the government of Jakutsk has been in their endeavours to destroy this superstition, they

* The hardened surface of the snow, occasioned only in spring by its thawing in the day and freezing again at night. 
have hitherto been very unsuccessful. They even sent an order to the town of Schigansk, for search to be made after the body of this Agraphenna, that it might be consumed; but this was equally inefficicious in its influence on the superstitious multinude. Their Jakutish schamans spare no pains to preserve the credit of the witch, declaring that they could never venture to lay any spirit without first offering a sacrifice to her; for were she in the slightest degree to be neglected, she would make her appearance among them and exercise her vengeance.

In January the cold rose to 43 degrees, and was so severe as to impede respiration. The very vapour from the breath was converted into icicles, which, from continual attrition, were incessantly crackling. The power of the sun was then too feeble to communicate any warmth to the atmosphere, making its appearance only for a short time at noon, on the summit of the horizon, and sending forth its rays in an oblique direction. It is worthy of observation at the same time, that the most perfect calm attends an extreme state of cold, which subsides instantly on the least motion of the wind. The thermometer, with quicksilver, was now rendered perfectly useless, the purest kind of quicksilver being frozen by a cold of 33 degrees; we were therefore obliged to content ourselves wilh spirits in its stead.

Whilst the weather permitted it, we had made some sporting excursions into the woods in pursuit of partridges and woodcocks, but now it was scarcely possible to pass from one dwelling to another. Our provisions, therefore, began to fall short, the season for fish being over, which had constituted our principal subsistence. Had we in this moment of plenty adopted a system of precaution and economy, we need not liave aggravated the sufferings from cold by those of hunger. We had then thrown away the head of an eelpout, which we now gladly scratched up from the snow, and eat with avidity. In addition to this, the scurvy, the common atteudaut on want, began to make its appearance.

During the month of November we had nearly finished one of our ressels, which was 45 feet in length, and received the name of Pallas. In the month of April we renewed our labours with a second, which was only 28 feet long, and named Jassachna. The ignorance of our carpenter, combined with the total inexperience of all the rest in every thing relative to the building of a vessel, naturally retarded our progress in this business; nor would it, perhaps, have ever been brought to bear, if the more intelligent of the party had not exercised their ingenuity in contrivance. The tar not being of a proper consistency which was procured at Jakutsk, we were obliged to mix 
sulphur with it, that was obtained from the larch-trees, which, when boiled together, produced a composition not inferior in quality to the best sort of pitch.

In the night of the 13th of May, a fire broke out in the habitation of the doctor and mechanic, owing, probably, to some negligence in extinguishing the coals on the hearth. The flames spread over the whole house in an instant, and extended to an adjacent store-house, in which the spirituous liquors belonging to the crown were preserved. Not the slightest article in the house could be saved, but happily no lives were lost.

According to several observations, we fixed the latitude of Werchne-kolymsk at $60^{\circ} 21^{\prime}$ north, and the deviation of the compass at $70^{\circ}$.

The river being now perfectly clear of ice, our vessels, which were in an entire state of readiness, were launched in very ligh water ou the 5th of May. After every necessary arrangement was made for our voyage, in which the command of the second vessel was consigned to me, we weighed anchor on the $22 d$, and were carried down by the stream with immense rapidity to the river Kolyma, which branches out into many smaller streams, that are lost in it again at the distance of a few versts. Many of these arms are perfectly dricd up at the fall of the water.

About noon we passed the mouth of the river Magaseika, flowing to the left, which received its name from the circumstance of magazines being built at its source not far from $\mathrm{Sa}$ schiwersk, in which the provisions were formerly kept that were afterwards conveyed by Saschiwersk to the fortress of Anadyrsk. The passage by the Kolyma not being then known, it was necessary to take the circuit of the two arms Magaseika and Oshogina.

Towards evening we received a visit of curiosity from a knask, residing on the banks of a little lake, who paddling towards us in his canoe, seemed very desirous to take a nearer survey of our vessel. Learning from him that the Pallas had not yet sailed past, we cast anchor until midnight, when it overtook us.

After passing on the 27 th the Cluster of Islands, as they are termed, which are seven in number, we reached the Trinity Islands, and river of the same name; probably so called from the hunters, who were going to erect a church here in the name of the Holy Trinity; but opinions being divided between this and another place, it was decided by lot, which fell upon the 
spot where Sredue-kolymsk now stands. The church, therefore, and soon after that the fortress, were there erected.

By Kamenka, a considerable river issuing from the mountains, which we left to the right on the 2Sth, as well as by the Troizka, the Jakuts and Tunguses catch many foxes, otters, unicorns, and sometimes sables, which are said to have been formerly very abundant in these parts.

Here, from the mouth of the Sranka to the fortress of Sredne-kolymsk, the Kosaks of Werchne and Sredne-kolymsk, have their summer encampments, for the purpose of providing themselves and their dogs with fish. They catch them with nets, and cure their jukol as usual by drying. 'The neolma, muksun, tschira, and, towards the autumn, herrings, are the most abundant here. In the evening we stopped at Sredne-kolymsk, a wooden fortress, situated on the left bank of the Kolyma, having a church and some houses. It was formerly called Jarman$k a$, (fair) because all the inhabitants from an inmense distance, as Tunguses, Jakuts, and Jukagirens, assembled here for the purposes of trade. 'They bartered their skins with the Jakutish and Kosak merchants, for tobacco and other trifling articles. The qaantity of skins, particularly from the sables, taken near the river Kolyma, was so considerable as to furnish a yearly revenue of 4000 to the crown, being a tenth of the whole amount; from whence this tax had the name of a tythe. 'T'he sables having all now disappeared from this quarter, the fair has, of course, been totally abandoned.

On the 17 th of June, we stopped at the mouth of the Omelon, on the left bank of which we discovered the summer encampment of the peasants of Omelon. During this season they are engaged in fishing until autumn, when they return to their village, lying about 20 versts distance from the river. On the other side of this village there are Jakutish kagireus still remaining.

The river Omelon, together with the Inshiga and the Oenshina, issues from a chain of mountains, and receives the addition of five rather inconsiderable rivers; three from the right and two from the left; one of which is the Magaseika abovementioned. Four hundred versts up the Omelon is an old wooden structure, erected probably on the discovery of the river by the Russian hunters, who had undertaken their excursion in kotschen*, from the river Lena into the Frozen Ocean, and from thence to the mouth of the Kolyma, which leads to the Omelon.

* A flat-bottomed vessel very similar to a barge. 
In a summer residence on this river, we found Captain Inshiginsk Schmalew Satnik. Kobolew, and the Tochukotish interpreter, Daurkin, waiting for us agreeable to appointment. They were to act as our interpreters with the savage people, called Tschukschens, whom we might chance to meet in the Frozen Ocean. Mr. Schmalew, who was destined for my vessel, was a man well qualified for this situation, having been some years commander of Inshiga, where, by his suavity and presents, he had gained the confidence and good will of the Tschukschens, who yearly resort thither for purposes of trade.

After lying at anchor but three hours, we followed the course of the river and reached Nisma-kolymsk, situated on the left bank of the Kolyma, in 24 hours. The fortress includes within its wooden barricade, one church and 33 houses; together with 33 Kosak inhabitants. Opposite to this fortress, the two large rivers, the Great Anui and the Dry Anui, run, at an inconsiderable distance, into the Kolyma. The former of these extends sog, and the latter 500 versts. The banks of both are inhabited by Jukagirens.

The swimuing of the reindeer across the Omelon and the two Anuis affords an extraordinary spectacle twice a year; viz. at the close of May, when the wild reindeer abandon the woods in great herds, probably with a view of seeking shelter from the guats within the neighbourhood of the sea, and afterwards in autumn, on their return; in both which cases they are obliged to pass these rivers. The Kosak and Jukagiren inhabitants of these parts, who know the favourite haunts of these creatures, repair then in their canoes to the spot, and pierce them in the water with the greatest facility, sometimes to the number of 60 in a day. They do not swim over all together in a body, but one after another; and as soon as their leader has reached the opposite shore, they are uot to be diverted from following him by any prospect of danger : if he, however, be interrupted in his course, he instantly returns, and the whole herd after him.

The flesh of reindeer forms a principal article of diet for the people of this country. They cut it into thin slices, and dry it after the manner of their fish. The marrow and tongue are esteemed as delicacies. Another luxury which they have, is red bilberries mashed with dried fish, and the fat of fish, with which they make their most costly entertainments in the summer. In the winter they eat frozen and raw fish in its stead, particularly tschirens, which they mince very small, and then give the name of strogannoi. It is reputed to be very salutary against the scurvy, for which reason we adopted it as a reguiar remedy during our winter stay at Werchne-kolymsk. 
We were detained four days at Nishne-kolymsk for the repairs of cur vessels; the smaller one in particular, which, for want of ballast, was frequently in danger of being overset. We took in likewise 30 puds of dried reindeer's tlesh, and 150 puds salted; which the Jukagirens cured for us with the salt we gave them, for this is a scarce article with them, and is obtained from $\mathrm{Ja}$ kutsk at an exo:bitant price. Whilst lying at anchor, we had clear warm weather and scarcely any wind, but were tormented with gnats to so immoderate a degree, that we were obliged to protect our faces and hands from them by a constant covering.

On the 19th, the Pallas weighed anchor and proceeded down the river. My ship not being ready, I could not sail until the third day after its departure. We had not proceeded 20 versts before we discovered three lofty mountains on the right bank of the Kolyma; one of which is called Pomtelegews, the other Sorowsberg, and the third Belaga Jopka. The Kosaks from Nishned-kolymsk have their summer encampment at the foo tof the first, by the river Ambonicha. Sixty versts from this fortress, the river Kolyma divides and falls by two branches into the sea. The course we took, which bore to the east, is called the Stony Way, probably from its right bank being occupied by stony precipices and stupendous crags.

In the aftermoon of the next day we passed the winter residence of the merchant Schalaurow, situated on the right bank. He undertook a royage in the Frozen Ocean, but finding too many obstacles to oppose his progress, passed the winter season here. The next year he made another trial, that proved fatal to the vessel and himself with his whole crew. The former being dashed to pieces by the ice, was thrown on the shore, and the latter perished by liunger, according to the account of the Tschukschens.

We descried likewise, at a distance of five versts, in a straight line before us, the lighthouse which Lueutenant Laptgew built in 1735, as he was surveying the shore of the Frozen Ocean. Not very far to the left of this lighthouse we observed an island not marked in Laptgew's map, which he most probably overlooked from its low situation, unless we are to suppose that it has made its appearance since that period. It is, however, at least fair to conclude, that the water has undergone some change within these late years, for otherwise he could not have gone on land to build the sheds for his people, which are still remaining. At present its depth in full tide is not sufficient to admit the smallest craft, and at ebb it leaves the bottom of the river dry for the space of three versts. 
Misty and stormy weather prevented us from making any great progress for three clays. On the fourth we descried the ocean, covered with inmense sheets of ice, that, at a distance, appeared to be one compact mass; but were, as we discovered on a nearer view, driven together towards the shore by a north-east wind and the tide. We endeavoured to penetrate betwixt the ice and the shore, but were compelled, towards evening, to give up the attempt, and seek a shelter under the projecting rocks of a little river flowing from the mountains. The shore extended by an ascent of four fathoms above the surface of the water to the rock of Baranow. It was covered with moss and sea-weeds, having here and there a scattered flower, willow, or shrub, that was almost too small to be distinguishable. The summits of the mountains, and even the declivities of the rocks below, were incrusted with congealed snow. Diring the three days spent here, we discovered four bears and a whole herd of reindeer.

The wind changing on the fourth day, and driving the ice more directly towards us, we were compelled to weigh anchor, and, with infinite difficulty as well as danger, to force our way close by the pendant rock. We succeeded very soon in finding a retreat near the opening of a mountain, from which issued a spring of pure water. Here we caught a vast quantity of herrings in nets, and saw some sea-calves.

From different observations we fixed the latitude of this place at $69^{\circ} 29^{\prime}$, although all maps bave hitherto assigned to the shore of the Frozen Ocean a position two degrees more northerly.

CHAP. V.

FRUITLES ATTEMPTS TO FIND A PASSAGE TO THE NORTH AND EAST.-ANCHORAGE OFF THF ISLAND OF BARANOW-REINDEER-WILD GFESL CHACE-THEIR PRESERVATION.-THE INHABITANTS OF THIS PARTPEMARKS ON THE FROZEN OCEAN.- RETURN TO SREDNETI OLYMSK.

$\mathrm{O}_{\mathrm{N}}$ $\mathrm{N}$ the first of July we weighed anchor, and made two trials to proceed, first in a northerly, and afterwards in an easterly, direction; but the mist and the ice were each time unfavourable to our designs. My little bark was frequently in danger of being shattered to pieces by the masses of ice which were driving around us with impetuosity, and at length our safety obliged us to retreat towards the shore of the rock of Baranow.

During our stay hei $\mathrm{e}$ we sent our steersman up the rock to take a survey of the ocean. He brought us the intelligence, that he had observed, from the snmmit of the loftiest mountain, SARYTSCHEW a] 
but one sheet of ice, which extended as far as his eye could reach to the east. We were satisfied, by this information, of the impossibility of taking an easterly direction, but desirous of obtaining ocular demonstration, the commander, doctor, and myself, set off for the same route. On our passage over the smaller mountains we met with several reindeer, which differ from the rest of their species by never leaving the sea-side winter or summer. They never associate with the others, whose tracks were likewise every where discernible. The lakes of these parts abound with wild geese of a large species, and a grey colour, called gumaniken: it being their season for moulting, they could not easily escape our pursuit. The Kosaks here catch them with great facility, by driving them in vast focks to the most distant shallow spots they can find, where they knock them down with clubs, and throw them into pits dug for the purpose. Here they lie for years without suffering the slightest change: for the earth with which the geese are covered, does not thaw even in summer to the depth of above half a yard. By this means, human bodies are kept in a ligher state of preservation than by the method of embalming; for not only the component parts of the frame, but the very clothing will thus remain unimpaired.

From the summit of the rock we also beheld the whole sea to the east covered with nothing but ice. The shore which bounds this glassy surface is not much elevated, but its extremity appeared to be a monntainous head of land, about 50 versts distance, which I take to be what is designated on Schalaurow's map by the appellation of Keschtscheinoi (sandy), that terminates at the bay, where he looked for the river 'T'schaum. It is possible for this to be the dwelling-place of the well-known Tschukotian, prince Kopai, from whom the Kosak Wiligin received the first jassak in the year 1723*.

On my return from the rock, I found an old wooden cross lying on the ground, with its underside perfectly decayed. The inscription, if there ever had been one, was now entrely effaced. From its apparent age, I should date the erection of it as far back as the year 1640, when this place was visited in cotschen (barges). I saw another old cross by the summer encampment on the Omelon, on which the date of the year $1 ; 18$ was still visible. The inhabitants of that part directer my attention to some holes supposed to have been pierced by the arrows of the Tschukschens, who sometimes used to attack the Russian establishments.

On the 17th we made another effort to put to sea, but had

* This jassak is an impost in kind, consisting mostly of furs, which, is every year demanded of the tributary nations in Siberia. 
not proceeded 30 versts before an indescribably thick mist impeded our advance, and the ice perpetually accumulating, su as to heighten our danger every moment, we came to the unanimous resolution of returning to the Kolyma, and directed our course round the rock of Baranow. This rock is formed by many contiguous momtains projecting with a cape into the sea, which describes a semicircle. On its summit there are many stone pillars, some resembling the rubbish of a ruined fortress, others bearing the appearance of remains of buildings falling to decay, and of the inages of men. While lying at anchor, we could distinguish on one of the lower mountains a pillar of this description, which seemed to represent two women in conversation, and holding a child between them. These pillars are in fact nothing but solid stone, from which the external incrustation of marl has fallen off. Besides a number of sturgeon and seacalves, we saw a whale here, an incontrovertible proof, that the Frozen Ocean has some connection with another sea to the north or the east.

In the afternoon of the $22 \mathrm{~d}$ we waited at auchor for the Pallas, in a little nook of the shore on the north side of the rock, where two projecting cliffs sheltered us against the winds and floating masses of ice.

The shore in the middle of this nook, which is steep and sandy, is enclosed on both sides by lofty mountains, from which issue many springs of pure water. Although this little vale afforded nothing more remarkable than a weed, with some unusually beautiful blossoms, yet the prospect of vegetable nature, even in her humblest attire, was truly gratifying to us, after having witnessed nothing but dreary objects for such a length of time.

At the brink of one spring, I discovered, at no great distance from each other, two subterraneous jurts in a ruinous state. On turning over the earth, they appeared to be round, and about three yards in circumference. In the interior we found the bones of reindeer and sea-calves, as also several earthen potsherds, and two stone knives with three edges, one of which was crooked and sharp, the other two straight and blunt. One of these knives I gave to the captain, and the other to the doctor. The Kosaks of Kolymsk informed us, that the former inhabitants of this place, who must have been unquestionably Tschukschians, called themselves Schalags, and on the settlensent of the Russians here, moved farther to the west, and took up their residence near the northern cape, from that time denominated Schalagian.

Of the wood, which is driven in great quantities to this shore, we raised a cross, and specified on it the day and year of its erection. During the time of our lying at anchor here, the ice 
perpetually drifted towards the east. The tide along the shore changed every day, or every other day, and the water sometimes gained the height of a foot, but never exceeded it, and even that occurred withont any regularity; which circumstance has given rise to the suggestion, that this sea cannot be of great extent, being bounded at no great distance by land to the north, and connected by a straight to the Northern Ocean. It is otherwise not easy to account for this deviation from the universal law of nature with regard to great seas.

The opinion that the continent lay in a northerly direction, was confirmed by a high south wind, on the $22 \mathrm{~d}$ of June, which continued with the greatest violence for 48 hours. Had there then been no hinderance, the ice must have been necessarily driven very far towards the north: instead of which, we found the sea next morning quite covered. Captain Schnalew also informed me, that the r'schukschians had spoken to him of a continent towards that point, not very distant from the Schalagian promontory, which was inhabited; and at the same time they observed, that the Schlagian Tschukschians used in winter to cross over to that place in a day.

The wind becoming favourable on the 26 th of July, we weighed auchor, and bore away, with a gentle breeze, to the mouth of the Kolyma, and from thence to Nishne-Kolymsk, where we landed in safety; and thus terminated our excursion in the Frozen Ocean, which was no less fatiguing than dangerous.

From the foregoing it is manifest, that any farther trial to cross the Frozen Ocean would have been fruitless. Mr. Billings therefore assembled the officers to consult on the easiest and least dangerous method of encompassing, either by land or sea, the Ichalagian and Tschukotian promontory. The way by the month of the Kolyma had already been proved by experience to be blocked up by the immense masses of ice. For although the sea has been found by preceding navigators to be sometimes clear, yet none of these enterprising mariners have succeeded in opening the passage to the Eastern Ocean, except Deshnew, a single Kosak, who made the experiment in 1648, in a barge. Great doubts, however, are entertained of his veracity, and it is strongly suspected, that Deshnew collected most of his information respecting those shores from the 'Tschukschians, and supplied the rest by his own invention.

But granting the truch of Deshnew's narrations, it only evinces that Nature may once in a hundred years deviate from her established rule. The Kosaks here assured us, that such quantities of ice are always in the sea as to prevent any one from going even ott of the river, and they considered this summer as having been umisually favourable for such an enterprise. But if we judge from 
the trifing warmth of this summer, and the faint influence of the sun's rays through the impeneirable mists, we may fairly conclude, that not half the ice is thawed in summer, which is formed in winter; not to mention, that the sea is the common reservoir for the ice of the surrounding rivers. From whence it follows, that the difference in the quantity of ice is not so much to be ascribed to any variations of the summer heat, as to the direction of the winds for impeding or assisting its passage out of the ocean.

One measure we had still in reserve, namely, that of going round the aborementioned cape in sledges; but this was rejected as impracticable, from the circumstance of not being able to supply the dogs with provisions for above 200 versts. At length we came to the resolution of giving up all farther thoughts on the matter until after our intended examination of the Eastern Ocean. For which purpose, Solnik Kobelew, and the interpreter Daurkin, were ordered to go to Inshiginsk, and from thence to accompany the Tschukschians, who frequent that place every year for the purposes of irade, to Tsukotskoi-nos, in order to apprise the various inhabitants of our arrival, and wait for us in Behring's straights. The cold in this climate now commencing, we frund it prudent to lose no time in making arrangements for our departure to Sredne-Kolymsk by water. Our vessels being accordingly umigged, and consigned to the care of the govenor, Martianow, the commander, with part of the crew, took boats and were rowed up the river, leaving me with the remainder behind to store the Jassachna with provisions for four months. The day after the captain's departure, a barge arrived at Nishne-Kolymsk with the necessary stores: this vessel I judged would be better for towing along the shoais of the coast than the large vessel; and packing therefore all my baggage in it, divided the crew into two parties, which were alternately to relieve each other. Thus disposed, we reached Srediu-Kolymsk in twenty days. The ouly circumstance worthy of note which occurred in this interval, was an aerial combat betwixt an eagle and two hawks, which was both an extraordinary and interesting spectacle. The two hawks first took a sweep in the air above the eagle; one of them then darted down with the intent of commencing the attack, but intimidated by the display of the eagle's talons, turned off', and shot past him. 'The other in the mean time seized the moment in which the eagle was off his guard to give him a blow so violent that we distinctly heard the sound of it; which was repeated by the first hawk, before the eagle could place himself in a state of defence. Feeling his in. feriority against two such powerful enemies, the eagle retired 
from the contest, and descending in haste, was closely pursued by the two hawks until he had alighted.

The roads to Jakutsk being impassable on our arrival at SredneKolymsk, we were obliged to wait for the frost, which sets in in September. On the 18th the Kolyma was covered with ice, and the inhabitants were engaged in their usual occupation of catching fish at the different openings they had made.

\section{CHAP. VI.}

IOURNEY FROM SREDNE-KOLYMSK TO JAKUTSK. MAMMOTH'S BONE FOUND ON THE SHORE OF THE FROZEN OCEAN. - LUDICROUS INCIDENT WITH TIE DOCTOR. - ARRIVAL AT JAKUTSK, AND DEPARTURE FROM THENCE FOR THE MAIA - BREAKING UP OF THE ICE IN THE RIVER ALDAN.-FLOATING ISLAND AND EXTRAORDINARY FLOOD.-RETURN TO JAKUTSK.

( $\mathrm{N}$ the 24th a part of the expedition was dispatched under the direction of Mr. Bakow, the master, whom I followed on horseback four days after, in company with the doctor, first surgeon, and mechanic. For the first 90 versts to Alaseisk, on the river Aleseja, we had to pass through woody marshy countries, and a number of lakes, three of which were not less than twenty versts in extent.

Alaseisk consists of a chapel and two isbens, inhabited by a merchant and a citizen, with their families. The neatuess of their little dwellings, and the hospitable reception we experienced from them both, were matter of surprise and gratification for us. We had not been prepared for meeting happiness, content, and good humour in this rugged and barren clime. But nature has amply supplied their want of corn, by fish, game, and cattle. The lakes abound with geese, ducks, and other species of wild fowl in summer, and in winter their habitations are encornpassed by immense flocks of woodcocks. The fish of this part are reckoned of superior quality, and the tchirens from the lake, are sent to all fortresses on the Kolyma, on account of their quality for keeping.

'The river Alaseja flows rery close by this hamlet, and falls immediately into the frozen Ocean. The inhabitants informed us, that about a liundred versts distance from hence, the river bad washed against its sandy bank the skeleton of a great animal, of which only one half was visible. It was apparently about the height of an elephant, in an upright direction, and in an entire state, still retaining its skin, and in some places, its bair. Mr. Merk had a strong desire to see this creature, but 
was prevented from gratifying his wish by a heavy fall of snow that had just taken place, combined with the immense circuit it would have occasioned in our journcy. 'The circumstance of a whole animal having been found on the coast of the Frozen Ocean, was a great curiosity, as we had hitherto never heard of any thing more than single bones and tusks, which are firequently collected, and form a branch of comnerce for a company of Russian merchants, who call them by the name of mammons knocken (mammoth bones). They are found in the greatest quantities on the Laccherishi Islands in the Frozen Ocean, opposite to the mouth of the river Jana. A natural question Fere arises, which is entitled to consideration. How could these animals have inhabited a draary climate, so ill suited to them, where the cold is intense?-Some are of opinion, that they are not natives of this place, having been brought hither from warmer countries in early ages for military purposes; others conjecture, that they were transported hither in the universal deluge: but both suppositions appear to me untenable. Such marihy, unfruitful, and mountainons comntries as these are, could never have been witness to any warfare in which elephants or the like univieldy animals were used; since the horses bere, which are inured to every species of fatigue, are frequently unequal to the task of travelling in these uneven and slippery tracks. Nor is it more probable, that any deluge (particularly at the very remote period of the universal deluge), could have carried animals with it to the distance of 5000 versts, which now separate this county from a warmer climate. For my own part, I an rather inclined to attribute this phenomenon to some extraordinary change in the globe, and suppose, that the elements in this quarter of the world were once more congenial to those animals than at present; and with this suggestion I shall leave the matter to the decision of the naturalist.

The road as far as Saschiwersk led us through a succession of woods, marshes, and lakes; two of which latter were nearly thirty versts in circumference. These lakes are in general all comected together by brooks and rirulets which run into the Alaseja.

On the 10th of October, the cold became severe in the extreme, insomuch, that an old man in our company of above sixty, master of our baidars, who had not our youth and vigour of constitution, to shield him from the inclemency of the weather, sunk into despair, and resolved on meeting his fate in the woods. With the utmost difficulty $I$ persuaded him to go on a little way farther, promising to leave him behind at the next habitation we came to We rery fortunately reached two isbens the next day, 
at the mouth of the river Ujandina, inhahited by two citizens, with whom I left our old man, to his no small satisfaction.

The town of Saschiwersk, lying on the right bank of the Indigerka, is newly erected, having formerly been nothing more than a commissariat. Every thing therefore at present is in its infancy; but it has already its court of judicature and the necessary appurtenances. It consists of a church, and thirty wouden houses. The marshy hilly country in which it is situated, the barreuness of the soil, and the want of every necessary, render it a gloomy residence; and when to this is added the exorbitant price of provisions, it becomes insupportable. Whatever is not procured from Jakutsk at the proper season, is not to be had for money.

We continued three days at Saschiwersk, and were entertained by the comsellor Sampsonow, bailiff of the town, and by judge Banner, with so much cordiality and kindness, that I should charge myself with ingratitude were $I$ to pass it over in silence. They furnished us likewise with provisions by the way, which we could not have procured at any rate without their aid, a favour not to be estimated by any pecuniary calculation.

Mr. Banner informed us, that on a mountain situated opposite to the town on the other side the river, there were fine crystals. At the desire of Mr. Merk, therefore, we repaired thither, but found only some small ones, owing probably to the quantity of snow that had fallen. He shewed us, however, a remarkable breach in the declivity of this steep mountain. Immediately after our return from thence, Mr. Billings made his appearance at Saschiwersk, which retarded our departure for another day.

We set off on the $22 \mathrm{~d}$ of October, and for the first days were continually crossing the brooks which run into the Indigerka, or passing over hilly countries covered with small larch-trees. On the 5 th day, at the distance of 120 versts from the town, we got among lofty open mountains, ruming in a chain from south-east to north-west, and separating the rivers that fall into the Indigerka from those that flow into the Jana.

We now followed the course of the river Russkaja Rossocha, upwards, which intersects these lofty mountains, and is bordered on both sides by steep crags that have the appearance of wallsa majestic spectacle! the banks of the river seeming to be one perpetual street of lofty buildings.

The passage along this river is, however, never perfectly safe. In winter, violent storms or whirlwinds sometimes bury the travellers in snow; and in summer they are in danger of being drowned by a sudden swell of the writer. These mountains are inhabited by foxes and wild sheep in abundance. One which we had the good fortune to kill, afforded us many pleasant meals: its flesh was peculiarly tender and delicious, or at least seemed so, 
to us. Twenty-five versts farther carried us beyond these mountiins, over a rivulet to the tolerably large river Dogdo, down which we proceeded for four versts, almost to its junction with another river, from whence it derives the name of Tostach, and soon after falls into the Jana. Our road now led us along the Jana itself.

On the 30th we spent the first night, since our departire from the town; in a warm Jakutish jurt, after having passed eight very cold nights in the wood. Captain Billings overtook us this night.

On the $3 \mathrm{~d}$ of November we stopped at the jurts of Barizlech the last dwelling-place on our road, from whence we had to travel 400 versts as far as the river Aldan, on the same horses; through uninhabited tracks. We of course took fresh horses here:

Such a distant joirney in weather that threatened to be daily more severe, was no pleasant reflection. The prospect of what we had still to endure, with which our former sufferings bore no comparison, inspired the most couirageous of us with a species of fear. We proceeded towards the source of the Jana betwixt open mountains, where the cold received a double edge; from the strong and piercing current of wind which they occasioned. Our treble clothing of skins was of little avail against the cutting air, which seemed to congeal one's whole mass of blood. We were every half hour obliged to alight, and relax our stiffened limbs by walking. Our faces were perfectly disfigured by the cold, and we should probably have lost our noses and cheeks; if we had not hit upon the idea of making ourselves masks of bog, which were very serviceable, but at the same time no less inconvenient; for they stiffened and chafed us very seriotusly. Our breath was likewise instantly turned to ice, from the confinement. In this half ludicrous and half terrible disguise, we had more the appearance of scarecrows, than of human beings.

We chose the most shady places possible for our nocturnal stay, not forgetting, however, fodder for the horses, and dry wood for fuel. Our fire served both for warming us, and dress ing our food. We never changed our clothes, and after supper, which was our principal meal in the day, we laid ourselves down in the cavities of snow. Happily for us all, not one of the party was assailed by illness; for in that dreadful extremity, death nust have been the inevitable consequence.

In ten days we arrived at the source of the tiver Jana, and at an unusually lofty, open mountain, called the Wercho-Janish, ot Upper Janish, from thence the rivers issue that run into the Frozen Ocean and the Aldan. The ascent of this mountain was much more gradual than its descent; which ptosented to our SARYTSCHEW.] 
view a hideously steep precipice that made us giddy, and obliged us to crawl on uur hands and feet when we could not take an oblique direction.

Proceeding along the river Tukulan, betwixt lofty mountains, we soon were cheared with the sight of poplars and larches. A few versts farther the scene was still more agreeably diversified by the evergreen of pines and firs, a rarity in nature which we liad not enjoyed since our departure from Jalsutsk; for neither of these trees is to be found from the Wercho-Janish chain of mountains to an immense extent northward, and from Jakutsk to Ochotsk eastward.

On the 19th of November we reached the river Aldan, and the first Jakutish jurts. On'our entrance, a ludicrous scene ensued, which was not so perfectly agreeable to the poor doctor, who felt limself violently assailed in the face, without being able to discover through his mask the quarter from whence he received the assault. From the shrieks, he doubtless corijectured it to be a female, as it in reality was, who, in a species of frenzy, had flown at the doctor to tear off his mask. After we had forcibly released him from her rude embrace, she continued screaming until she fell exhausted and senseless to the ground. The Jakuts regard such fits as a species of disorder attributable to terror, to which their women, particularly those in years, are very much subject. The patients in this case, have the name of miratschkens. Miserable as our jurt was we enjoyed a night of sweet repose; under other circumstances, the stench alone from the cattle would have rendered this place insupportable, but now a warm shelter compensated for the want of every other convenience.

The distance from hence to Jakutsk was 150 versts; a comparatively agreeable journey for us, with a constant change of horses, and succession of villages. We accordingly reached our point of destination on the $24 \mathrm{th}$, and experienced that heartfelt satisfaction at the termination of our toilsome and painful journey, which is conceivable by nune who have not endured similar fitigues.

Mr. Billings had arrived there some days earlier, and $\mathrm{Mr}$. Pehring bad been cccupied, during the summer, with dispatching the materials for Ochotsk. They had prepared us warm. rooms, which were altogether commodious, though without any elegance. The reception we met with from the inhabitants, and the commanter Marklowski, contributed no less to render our stay in this city perfectly agreeable.

Where was at this time in Jakutsk, an English traveller of the name of Ledyard, whose eccentric conduct excited consideral) attention. WTe was known to Mr. Billings, from having 
been with him in the capacity of a corporal in Captain Cook's last voyage; after which he is said to have bien a colonel in the army of the United States during the war. He had formed the design of going round the world in the literal sense of the word, and for that purpose went to Petersburg, in order to begin with liussia; and on reaching the eastem boundaries of Asia, to wait for some vessel in which he might pass over to the English settlements. The absurdity of this enterprize is sufficiently manifest, from the circumstance of his intending to travel throngh a civilized country, without money or letters of recommendation; and afterwards to cross those boundless tracks on foot, thinly clad in winter, through which we had laboured with infinite difficulty on horseback, and in the warmest clothing. Where would he have found an opportmity of being conveyed over the water to the place of his destination? and supposing that be could have ingratiated himself with the savages, yet what endless mountains and deserts lie between Russia and the single inhabited coast in those regions! He was relieved from the necessity of walking as far, as Jakutsk, by the civility of the Russian travellers, whom he met on the road, who carried him from place to place without any recompence. Here he met with still greater kindness, being admitted to the house and table of the commander, and receiving as a present from him a warm dress, more fitted for the cold season, which had commenced: and yet, the only return which Mr. Ledyard nade for this extraordinary hospitality, was to calumniate and abuse every one; and finally challenge his benefactor for remonstrating with him on the impropriety of his behaviour. The arrival of $\mathrm{Mr}$. Billings, at this moment, prevented any farther serious consequences from this affair, by his taking this man with him to Irkutsk 'on his departure for that place. The commander wrote a letter of accusation against him to the governor-general, in consequence of which he was taken into custody on his arrival at Irkutsk; and sent from thence to St. Petersburg, on the charge of disorderly conduct.

In Mr. Billings's absence I was commissioned to set off to the mouth of the river Maia, for the purpose of building there 50 canoes. I therefore first dispatched the steersman with some of the people, and followed him as soon as I bad collected the building materials. After crossing the Lena, we passed through woods, meadows, and lakes, in the course of which we occasionally met with scattered jurts: these were, however, quickly succeeded by bare mountainous countries.

On the fourth day of our journey, about 162 rersts distance from Jakutsk, we came to the slobode Amginsk, which. was remarkable for having been formerly the seat of the wogewodship, 
or bailiwick of Aldan. The buildings of this slobode cansist of a church, and 20 farm-houses, belonging to Russian settlers As winter grain does not thrive here, the peasants only sow summer corn, which answers very well. A tschetwerick, or 360 pounds of barley, formerly cost only eight kopecks; but the neglected state of agriculture at present, has more than trebled this price. The peasants, allured by the easy lives of the Jakuts, attend to the breeding of cattle, in preference to the culture of corn; and attach themselves daily more and more to their barbarous neigh. bours, whose manners and even language they have adopted. Four versts from this slobode, is a village of $1 \dot{2}$ jurts, inhabited by Russian peasants, who have laid aside their native language entirely. Five versts from the slobode, we crossed the Amga, Howing from the mountains on the right side, which it had washed away, and converted into huge precipices. On the left, were spacious fields, interspersed with little woods, or almost imperceptible ascents.

From the Amga, the road led by a little broak upwards, be? twixt the mountains, on the plains of which we proceeded 15 yersts to the river Notora, which, winding through a succession of fields, groves, marshes, and lakes, is finally lost in the $\mathrm{Al}_{4}$ dan. Descending by this river, to the distance of 28 versts, we turned off to the right, and proceeded by an insignificant chain of mountains, up to the source of the river Mukua, which falls through a number of lakes and marshes into the Alcian. We pursued the course of this river downwards, which ran betwixt mountains that gradually diminished as they approached the $\mathrm{Al}$ dan, until they terminated in simple rising ground. The moun: tains were all covered with larches.

On the 28th I reached the haven of Elssmaia, where magazines and two barracks had been erected in the former expedition of commodore Behring. They stand on the left bank of the Aldan, opposite to the mouth of the river Maia, that flows into the former on the other side.

The distance from Jakutsk to here, is reckoned to be 360 . versts. The northern latitude of this place, according to my observation, is $60^{\circ} 17^{\prime}$, and the declination of the compass, $2^{\circ}$ westward. Agreeably to my instructions, I begun immediately to collect wood for our canoes, and found a sufficient quantity of good materials on the banks of the Aldan. I preferred, however, the firs to the larches, on every groun'?

$\therefore$ The water commenced to rise on the 1st of May, and was 11 feet on the 9th, when the ice on the river Maia broke, and occasioned also a fracture in that of the Aldan, towards the lower part.

The swell increasing on the 13th to twelve feet, the whole of 
the Aldan was released from its confinement. The ice drifted vith extraordinary inpetuosity, and in "immense quantities, for three days; and in this universal agitation of ice and water, we perceived a floating island, about 70 fathoms in circumference, bearing with it a quantity of little birch shrubs, larch underwood, and cut wood; a considerable number of little birds, hopping from tree to tree, increased the singularity of the scene. As this island passed very near our shore, we could distinguish very clearly that it consisted of turf, and probably of a fen tom away by the water, which, in its present congealed state, had no effect in dissolving it.

The rise of the water continued till the $17 \mathrm{th}$, and concealed every thing for an immense distance from the eye, that was not above 38 feet in height. For seventy versts up the Aldan, by the way to Udskoi, the inundation was dreadful in the extreme, as we learned from a man who had been to Udskoi, for Captain Fomin. He assured us, that some places, 60 feet high, were buried under water.

The Jakuts, and all in that road, were material sufferers by this deluge; more than three hundred pack-horses, with a number of other things, being lost in the water. Captain Fomin, of the navy, who was just come from Petersburg with a special commission, experienced the loss of all his provisions.

On the fall of the water, we caught pike and sturgeon of different kinds with nets; perch and plotwen (Cyprimus idus) with the rod. The latter is a very scaly fish, weighing a pound at the utmost. Its head and fins are very large; its cirri close by its eyes, which have a broad rim round them; its whole body is covered with thick scales; its back round and dark green, but the sides and belly silver-coloured. Its pectoral, dorsal, and anal fins are dark; its lateral ones purple. It has an extraordimary quantity of spine, is found in pure sweet waters, and is very prolific and cheap.

On the 28th of May, the canoes being finished, Mr. Fomin proceeded up the Maia with two of them. A week after, Captain Behring came with his people to me, and taking the rest of the canoes, went up the river, in order to convey to Judomskoi-Krest the baggage which had been left the preceding year on the bank of the Judoma. Having consigned the crew, hitherto under my orders, to Mr. Behring, I returned to Jakutsk, in order to observe the state of the roads. I found them totally ruined by the rain and floods; and all the bridges which had been erected over the smaller rivers carried away.

I arrived on the 12th of June at Jakutsk, three days late: than our commander. I informed him of the state of the roads, and pointed out to him the repairs which I conceived necessary, 
As our baggage was already at Jakutsk, we hastened to send the order of the magistrate to the Jakutish Knasks on the Amga, to have the roads mended without delay.

CHAP. VH.

TRANSPORT OF TIE BAGGAGE TO JUDONSKOI-KREST.-

DIFFICULTIES ON THE PASSAGE.-RIVER-TUNGUSIANS. T -GLUTTONY OF THE JAKUTS.-ARRIVAL AT OCHOTSK.

IIE conveyance of the baggage to Judomskit-krest being confided to me, I proceeded on the 14th of July to Usmaiash Pristan, where I found a vast quantity of stores, which had been transported upon telegas, or four-wheeled carriages, drawn by oxen. The next day I disposed all the luggage in 17 canoes, and attended them myself down the river. Each canoe held 70 poods, and the whole burthen, of which our ordnance and anchors formed the principal part, amounted to 1500 poods. Lach canoe drew three feet of water, and the whole was dragged along by 120 men, who were principally Jakuts, hired for the purpose.

We set off at midnight from the above-mentioned place, and crossing the Aldan, came to the mouth of the Maia, which is 300 fathoms broad, and nine feet deep in the middle. But we soon found places where the river in its whole breadth is not above five feet deep. The water was then likewise two foot higher than ordinary.

At first the stream was so gentle as to admit of our rowing, but the tide gradually gained strength as we went on farther. Both sides were covered with small larch-trees, and occasionally with shrubs of different kinds. The right bank is so low, as to be continually overflowed; but the left bank is in some parts 20 , in others 60 and 80 toises high. It is also very rocky in many places. Farther on, the mountains of the left bank gradually decline so low as to leave the shore under water; while on the other hand, the right side begins to rise, and is continued by a rocky declivity for some distance.

Here we found some River-Tungusians, so called from their having no reindeer, and paddling incessantly about the river in their birch canoes, which serve at the same time for their habitations. These canoes are very small, and much in use among the Jakuts, in lakes and rivers. They are composed of twigs, plaited round long poles, which answer the purpose of ribs, and are altogether covered with the bark of the birch tree. 'The cavities are filled up with a sort of cement, which the Jakuts extract from boiled cream. These people, who live entirely or 
Gsh, are dot minated Tungusians, but are in reality of Jakutish extraction, and very rarely speak lungusian. I took one of them as my guide, to toll me the names of every river, cliff, or island we might pass.

After we had gone 85 versts, on our way to the Judoma, the left shore began again to be mountainous, and we found by the river Ilschikit, a rocky declivity called Elslank, about 60 toises in height; where we discovered for the first time lofty firs among the larch trees.

On the 9th day of our journey, we turned to the left from the river Maia up the Judoma, the breadth of which was 150 fathoms at the mouth. At a short distance from hence, it is only three feet deep, and has a very gravelly bottom. 'The stream is at the same time so strong, that thirty men could not tow a single canoe along, without the greatest dificulty. Such places in rivers have the name of Schewera.

We were obliged to stop about a verst and a half from the mouth of the river, to repair a canoe which had struck upon is stone. We kept close to the right shore, which was very long, and covered with all sorts of bushes, among which we found the currant and white vine; the latter beautiful shrub has the vame of dikuschac in Sibcria. The opposite shore had a large rock in one place, called Sourdschag.

Twenty-four versts farther, we had to drag up a schewera with still greater dificulty. The tow to one of the canoes breaking, and unfortunately just above the place where the girdle of a Jakut was tied, he was thrown by a jerk into the water, out of the reach of all assistance.

We experienced the inconvenience of shallow water for some time after, and as soon as this evil was removed, it was succeeded by one equally serions, namely, the sickness of our men. The greater part of our labourers had such bad feet, that I almost despaired of reaching Judomskoi-krest this summer. Their disorder consisted in a swelling of the toes and heels, and a chapping. of the hands. A regular application of tar and grease was found to be of immediate efficacy. The principal cause of this evil, was the sharpness of the water in the Judoma, in which the men were obliged to be continually wading. I observed, however, that the Kosaks were not so seriously affected in this way, as the Jakuts, and particularly those who had consumed their portion of fat and butter, and were now confined to their burduck.

This failure in the stock of their provisions originated with the intemperance of the Jakuts, who seized every opportunity that offered for devouring their allowance as long as it lasted. We no sooner stopped to rest, or spend the night, than they had 
their kettle on the fire, and did not leave it until we pursued ots journey. They spent the intervals of rest in eating; and practised petty thefts on each other, when their own stock was exhausted. Thus they passed the whole night without sleep, and were drowsy throughout the nest day.

It might naturally be expected, for such extraordinary voracity to be attended with ill consequences; and yet this was by no means the case. What they made a practice of devouring at one meal, would have killed almost any other person; but on them it had no visible effect. Their stomachs seemed to be of the ostrich kind, well fitted for the task of perpetual digestion.

One of our men had an allowance of four poods of butter and fat, (above 100 English pounds) and two poods of rye-flour, an ample provision for the heartiest labourer; and yet a fortnight had not elapsed, before he began to complain of having nothing to eat. I could not credit what he said, until the other Jakuts informed me, to my infinite astonishment, that this man occasionally constumed at home, in the space of 24, hours, the hind-quarter of at large $o x$, and half a pood of fat, with a proportionate quantity of melted butter for his drink. But the appearance of the man did not bear them out in their assertions; for he was small of stature, and very meagre. Having therefore a mind to make the trial of his gormandizing powers, I had a thick porridge of rice boiled with three pounds of butter, weighing together 28 pounds. Although the glutton had already breakfasted, yet he sat down with great eagerness, and, to my perfect amazement, consumed the whole without stirring from the spot. 'The extension of his stomach betrayed indeed a more than ordinary fullness, but otherwise, he discovered not the slightest symptom of having been injured or molested by it; and would in fuct have been pres pared for the renewal of his gluttony the next day. I advised our cormorant, however, to practise a little forbearance in future, and portion out the allowance given him for the time appointed. He now abstained from making himself any more porridge, and mixing his flour alone with cold water, ate it in that raw state, that he might be the sooner satisfied.

The banks of the river continued, as before, to be partly so low as to admit the water over them, and partly mountainous, according as the river itself wound through a high or low country. The wood consisted principally of larches, with here and there of poplars, alciers, and others. For the distance of 250 versts both the banks were enclosed by, or ran parallel with mountains, from whence this track is called Stscheki, (cheeks). On the 7 th of August the water rose within 24 hours so high as to break its bounds, and by the violence of its stream, brought a quantity of wood iato the siver. I should conclade from this 
extraordinary swell, that there must have been very heavy rains at the source of the river. We were compelled to stay three days in one place, to wait for the fall of the water. I fixed the latitude of this place at $55^{\circ} 2 y^{\prime}$.

Oil the 29th of August we were obliged to stem the tide below a waterfall, which extended two fathoms, and in which both banks were filled with pointed projecting stones. It cost us no small trouble to drag our canoes against the stream betwixt these stones. In the middle of the river, we conld see nothing but foaming and dashing waves, instead of stones. 'T'wo versts farther brought us to the proper cascade, which falls perpendicularly from a height of six feet. It does not extend over the whole bed of the river, but only from the right shore to a little stony island in the middle. But althongh there was no waterfall on the left side, where we were, yet the stream was so powerful, and the water so shallow, that we were under the necessity of lightening our canoes. Beyond this cascade the river was clothed with islands, and after ruming, as it were, in a chamel betwixt mountains, it was divided into a number of arms. The number of scheweras and dry places now increasing, we could not tow the canoes any longer, but were obliged to push them forward with our hands. To complete our misfortune, the cold weather now commenced. The morning frosts chilled the water to such a degree, that no one could 'endure to stand in it for any length of time. The people, particularly the Jakuts, grew inpatient and rebellious, obstinately reiusing to labour any more. Finding that neither threats nor intreaties were of any avail, I was obliged to try the power of example. I waded therefore myself for 25 versts through the water, and thus succeeded in bringing us out of this difficulty.

All these arms are again united at the distance of seven versts from Judomskoi-krest. Here my steersman had the misfortune of oversetting one of the canoes in towing round the point of an island, by which a part of the lading was lost.

On the $27^{\text {th }}$ we arrived safe at our journey's end, and unloading our stores immediately into the magazines, $\mathbb{I}$ dismissed the labouring Jakuts, that they might return home in the empty canoes. The latitude of this place, according to my observation, was $59^{\circ} 53^{\prime}$.

As there were no horses here for conveying our goods, I was obliged to leave them in the care of a Kosak, and proceed, with the few horses we could get, towards Ochotsk.

On the 1 st of October, we passed two isbens, and magazines, called the faehrbaute (ferry-dock) of Elrak, which were erected on the former expedition of Behring; for here the ferries and canoes were built that served for carrying the provisions

SARYISCHEW.] 
down the river Elrak, which were afterwards transported to Ochotsk in larger craft. But now the water in the Elrak was much too shallow to admit of any navigation with the smallest canoes, even when empty. Nor would it ever be practicable at any other time than in the spring, when there is an extraordinary swell of the water. All the rivers in these parts issue from the mountains, and are in connection with springs and rivulets that have also the same source, by which they receive extraordinary supplies of water, that are with equal rapidity carried off through other channels.

Keeping along the right bank of the river Elrak, we continually observed poplars, birches, and every sort of shrub intermixed with the larches, which cover its islands and shores. The former serve as a haunt for the woodcocks, which feast here, in great numbers, on the berries in this season, which render their flesh very delicious. In the spring they lose their fine flavour, and contract both a taste and smell from the buds of the larches, which is their only nutriment.

Eighty versts from the ferry-docks, we had to cross the Elrak, and turn off to the left over hills which brought us to the Jakutish place called Meta, on the Ochota. The remaining part of our jouncy, which was 70 versts, we went in birch canoes down the Ochota, with an immensely rapid stream, in six hours.

Mr. Billings staid but ten days at Ochosk, from whence he returned to Jakutsk. Our luggage, which had been left at Judomskoi-krest, was brought here in nartes, drawn by dogs, and we spent the remainder of the winter in ship-building.

At the commencement of spring, I surreyed the mouths of the Ochota and Kuchtui, and sketched a plan of the city Ochotsk, the northern latitude of which $I$ fixed at $59^{\circ} 18^{\prime}$. The easterly inclination of the compass was $0^{\circ} 40^{\prime}$.

\section{CHAP. VIII.}

YOYAGE FROM OCHOTSK TO THERIVER URKAN.-DREADFUL STORM.-THE ISLAND OF NANSEKAN.-THE BAY OP ST. THEODOR.-PASSAGE FROM ULKAN TO ALDOMA.OBSERVATIONS ON THE ESTABLISTMENT OF A HARBOUR ON THE ALDOMA.-ON THE RIVER AMUR.RETURN TO OCHOTSK BY THE ULKAN.

(1) $\mathbb{N}$ the return of spring 1 proceeded, agreeably to my commission, to survey the south-western shore of the Ochota, as far as the river Ulkan. My wooden baidar, which was about 23 feet in length, was finished in April, but the ice prevented me 
from setting out before the 3 lst of May. The crew consisted of ten men, and two subalterns.

The first day we had both wind and tide against us. The following day we passed the river Ulrak, which we could not enter on accomint of the boisterous weather, and rapidity of the stream. Not far beyond the Ulrak, two rivers of no remarkable magnitude, namely, the Tschitschikonka and the Cliomot, fall into the sea. They both take their source from the Urakish mountains, at the distance of 30 versts.

We were prevented by the storm for two days, from approaching the shore. On the third we were carried with the stream, to the entrance of -the united brooks Mariakanka and Andytscha, which flow about 40 versts from the adjacent mountains. Between the Mariakanka and the Chomot, is a lake ten versts long and one and a balf broad, running in a parallel line with the sea.

Notwithstanding the violence of the stream with which we had to contend, we managed to enter the river Ulga the next morning; which is about 75 fathoms broad. We observed no sand-banks at its entrance, and no shoals where the water was not two feet in depth. On the right side of the river is a bay, which extends from thence seven versts close by the sea, and is about half a verst broad. The left bank runs near the brook Elogan, which occupies nearly 150 versts in extent of country, and flows also for seven versts close by the sea. It receives the addition of several other smaller brooks.

The river Ulga springs from the same mountain as separates the Uikan from the Maia. Two hundred versts from its mouth, it has a cataract of suci an extraordinary height and steepness, as to prevent any canoe from passing by it. According to the assertion of the Tungusians, this river affords a great quantity of timber, at a considerable distance higher up.

We were detained here a whole day by bad weather, in which we had a succession of rain and snow. The surrounding mountains were entirely covered with the latter.

The shore, from Ochotsk to this place, is remarkably low; but rises at the distance of 15 versts by a chain of mountains, that gradually approach the river as you proceed farther, and form several roeky declivities. In this country we found three jurts of Reindeer 'rungusians, who were setiled here, for the purpose of catching bears, which are allured by the sea-reed that is thrown up, to frequent this shore in rast herds. They are very quiet, and even afraid. of men, who kill them without any difliculty.

The next day we passed the river Guntscli, which is eleven fathoms broarl at its mouth, and has its source in the southwestern chain of mountains. The two rivers, Nandakan and 
Elba, flow into it, the one from the right, and the other from the left. Among the stupendous crags which extend along this river was one called Chanandga, which projected at the height of 100 fathoms into the water, and attracted our attention from the number of sea-lions which were lying on the stones under the declivity. The summit of this rock is a haunt for birds of va ious species, as the tschaika or mew, the urila or Pelaeanus ir lnceus, ara, alca torda or penguin, toporka or Alca artica, and the kamenuschka, Anas histrionica, or fenduck.

Near this promontory we were overtaken by a violent storm, which dashed up the waves mountains high in its violent coniention with the opposing tide, and threatened every moment to swallow up our little bark; but the wind being favourable, the baidar sailed with such immense rapidity, as to escape every overwhelming billow, and brought us in a short time to a less dangerous spot: but on approaching the shore, betwist the rocky precipices, our baidar received a violent shock, by which it was thrown on its side, and many of us compelled to wade through the water to the shore for our own safety.

While ve were drying our clothes and provisions, the storm bsided, and enabled us to pursue our course, which led us su ast the steep mountain Enkan, that projects into the sea. At is extremity there was a stone pillar, about seven fathoms disit ant, which was nearly the height of the mountain itself, and had

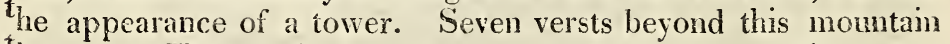
the brook Kekra falls into the sea, after having received two tother rivulets.

Shortly after we discovered on a small island, opposite to the cliff Odshan, four jurts of Reindeer Tungusians, who are settled here for the purpose of hunting bears on the sea-shore, and wild sheep on the mountains. In the summer they collect vast quantities of eggs from the sea-birds that frequent this coast, and nest in the hollows of the rock.

The next day we reached the river Ulkan, which was appointed by Captain Billings as our place of rendezvous. 'The breadth of this river at its mouth is nine fathoms, and its depth at low water, three feet; but farther on, only a foot and a half. The latitude of this place is $57^{\circ} O^{\prime}$, the elevation of the tide, six or seven feet, and at the new moon, nine or ten feet.

I was induced, from the short distance of the river Aldoma, and from what I had heard of it, to embrace this moment of leisure to pay it a visit, and accordingly set off on the $J$ th of June. Ire arrived towards noon at the Aldomish bay, which takes its name from the above river, with which it combines towards the west. The greater part of this bay is dry at low water, and the rest is not above $5 \frac{1}{2}$ fathoms. 
The Aldoma has two sources, namely on the Jablonish mounfains, and on those from whence the Ulkan springs. At its mouth we found three jurts of Tungusians, who subsist alone on fish, which are similar to those at Ochotsk. The Reindeer Tungusians come also here to fish at the close of June.

Although they assured me that the banks of the Aldoma prosluced no timber, yet I observed anong the floating wood some pieces four yards in thickness, and twelve or fourteen in length.

During my stay in the Uldoma, I had the unexpected pleasure of meeting with Mr. Fomin, who was just come from the Uda. Whoever has experienced the agreeable surprise of meeting a friend or acquantance in a savage and desert quarter of the globe, will fully cnter into our feelings on this occasion.

Mr. Fomin was commissioned to plan a harbour on the Uda, but its entrance being two shallow, and otherwise incommodious for the reception of vessels, he had surveyed the whole of the Uda as far as the Chinese frontiers to the east, and the Aldoma to the north-east, but found nothing worthy of his attention, except a bay in the latter river, which was perfectly sheltered on all sides, except towards the south. Besides these two rivers, there is only the famous Amur, which after passing through 400 versts of the Chinese territory, falls into this sea.

This river formerly belonged to Russia, and between the years 1664 and 1689, aturicted the Kosaks and hunters from the different nations in the Russian dominions, to its borders. Cities, fortresses, and villages, were built, and agriculture introduced. The land is fruitful, and the water abonuds in fish; the inhabitants therefore lived in opulence, and would in time have converted this tract of counitry into the most fourishing part of Russia, if the envy and jealousy of the Chinese had not been roused against these new settlers, to impede their farther establishment. They sent a considerable force for the purpose of destroying their cities, and although they met with a stout resistance, yet by a treaty concluded between them and the Russians, the latter retained only the upper part of the Amur, under the name of the rivers sichilka and Arguka, the contluence of which forms the new frontiex. All beyond this point was ceded to the Chinese, and the Russian city Albasin, together with the Argunsk on the solithern side of the Arguna, and adjacent places, were destroyed. The city of Nertochinsk only was savei, and and afterwards anothic fortress of the same name was built, on the north side of the Arguna.

The Chinese have not derived the smaliest advantage from this possession of the river, which, by remaining in the hands of the 
Russians, would have made them masters of the Eastem Oceass, and secured to them an extensive trade in those seas.

Having sent our people forward with the baidar, I staid two days longer with Mr. Fomin, in order to accompany him on reindeer to the Ulkan, where he arrived after a jouncy of 30 versts in six hours, and found a tent erected for our reception. $\mathrm{Mr}$. Fomin did me the kindness of stopping with me two days, at the end of which he set off again for the Alduma.

The interval of waiting for our commander, was employed by the men in the pursuit of sea-lions near the promontory of Enkan, two of which they succeeded in shooting, after two days chace. They are commonly shot as they lie extended on the rock, and at so short a distance, that they may be hit on the crown or temples, the only two parts in which they are to be mortally wounded. On receiving a wound in any other place, they spring into the water, and sink to the bottom the instant they die. The flesh of these two animals, which weighed nearly 80 poods, was a sufficient load for my rhole baidar; the men ate of it with much avidity, and esteemed it a great luxury, although I did not find it equally delicious. The paws, marrow, and kidnies, indeed, were free from any offensive smell, and had a tolerable flavour.

In consequence of a counter order from Captain Billings, not to wait for him here, but to return to Ochotsk, I set off from this place on the 27 th of June. In my way thither I passed the mouth of the river Ulga, and entered the Urak. The breadth of this river is 70 fathoms at its mouth; its depth, at the fall of the water, five or six feet, and higher up, two feet, or a foot and a half. Three years ago the Urak fell into the sea farther towards the west; but the small neck of land, which separated it from the sea, being washed away by a flood, it forsook its former mouth, and took this new course.

The bank of the Urak is inhabited by some Jakuts, who have removed from Jakutsk. The merchant Ichelechow has also erected some barracks here, and a dock-yard, in which he built three vessels.

On the rth of July, we arrived at the mouth of the Ochota, where we were received by aimost all the inhabitants of the city. Our conmander, and the rest of the expedition, were at Ochotsk. I presented him with my joumal and map of my late excursion, and received the command of the ship Slawa Rossii (the Fame of Russia) which was already launched and equipped. The length of its.deck was 86 feet 6 inches; its depth, 9 feet 6 inches; and its breadih, twenty feet eight inches. The second vessel, which was $5 \frac{\mathrm{I}}{2}$ feet smaller than the former, and received the name of the Dobroe Namerenic, was launched the next 
day. Both vessels were laid at anchor in Ochota, opposite the town, and the utmost exertions possible used to fit them ouc complete for sailing; but this was attended with infinite difficulty for want of proper hands to execute the business. The Kosaks, who had been sent us insiead of sailors from all parts of Siberia, were not only total strangers to the sea, but to every thing belonging to a vessel; and were not very expert in learning this new calling. Nor did we derive much greater assistance from the sailors in the haven of Ochota, who were altogether unused to the equipment of vessels like ours.

CHAP. IX.

THI TWO VESSELS GO INTO THE ROADS.-DESTRUCTION OF. THE DOBROE NAMERENIE. - SAILING OUT OF THE OCHOTSK ROAD.-DISCOVERY OF TIE ISLAND JONAS.NAVIGATION BETWIXT THE KURILIAN ISLANDS.ARRIVAL AT THE BAY OF AWATSKA.-ENTRANCE INTO THE HARBOUR OF PETROPAULOWSK.

$7 \mathrm{~T}$

HE ship Slawa Rossii was, notwithstanding every impediment, completely equipped in August; but we could not load her deeper than $8 \frac{1}{2}$ feet, as there are many sand-banks at the mouth of the Ochota, which are not above nine feet deep. 'These sand-banks, which we were obliged to pass, extended a verst and a half, and although we could have easily effected this in half an hour with a good wind and full sails, yet we were obliged to tow the ship along the shore for some days, and to stop twice a day, about eleven o'clock, by the shallow places. Not to mention that our towing was sometimes of no avail, when the bottom was extremely uneven, and the tide very strong:

After we had succeeded in getting the vessel over the sands, we turned off from the shore of the river Kuchtin, to the other side of the two united rivers, where we found it a suitable depth.

We threw out all our anchors for the sake of security, and thus, for two days, remained quiet; but on the third, as the tide fell, the stream was so violent as to tear the ressel from its anchors, although it was fastened by a cable to the shore. We were accordingly obliged to remain 12 hours lying on a shoal, from which we were released by the return of the tide on the following day, and cast anchor against the side of the river.

On the 27th of August, this vessel went out, with a favourable wind, into the roads, and anchered four versis from the shore, in six farhoms. The captain went on land, consigning the managemest of the landing; and every thing else, to my care. 
In the mean time, the final equipment of the Dobroe Nanerenie being completed, it set sail from the city to the mouth of the river, where, on the sth of September, we winessed the beginning and end of its navigation. As we were on the point of carrying her out of the river, the wind, which had filled our sails with a favourable gale, sudidenly dropped, and was succeeded by an extraordinary swell of the sea, which drove a-head of us, and occasioned a horrible reeling of the vessel. It scarcely moved forwards, and was with difficulty kept off a sand-bank, against which it was perpetually forced by the towering billows. Towards eleven o'clock, the beating of the waves increased, and the shallops, with which the vessel was towed on, being thrown into disorder, were thus rendered disserviceable. 'The next instant the ship lay on its beam ends, fast in a sand-bank. It vas now enveloped in a furious vortex of billows, that dashed with indescribable vehenence and velocity from side to side, and carried away all its masts. In this distress it was impossible to afford any assistance. The inhabitants of the town, who had flocked to the shore, were obliged to stand as idle spectators. raging of the waves equally prevented any one from rowing tip to the ressel, as it did the crew from getting on land. The one now beheld the dreadful spectacle with leartfelt compassion, and the other awaited their inevitable fate in despair. With every wave that followed in rapid succession, the ship was heaved backward er forward with such violence, as to shake the men from the cable on which they hung. Some were even hurled into the water, while others were threatened with being dashed to pieces by the broken masts. In this dreadful and pitiable condition they were obliged to spend four hours, until the return of the ebb, which appeased the fury of the waters. We immediately cleared the ship of the cargo and provisions, and made every endeavour to drag it to the shore, but were twice prevented by the tide setting in more impetuously than before. Finding therefore, on examination, that the vessel was too much damaged to admit of repair, Mr. Billings, and the officers, unanimously resolved on having it burnt, in order, at any rate, to preserve the iron. On the evening of the gth, therefore, we had the mortification of seeing our vessel, the Dobroe Namerenie, which had cost us so much pains, anxicty, and money, consumed by the flames.

The agitation of the water continued for three days, particuarly at the mouth of the river, where the surge beat with such vehemence against the breakers, as to prevent our getting on land. I now expected that a high wind would have succeeded from the quarter where the sea had been so tumultuous: but, on the contiary, it continued a perfect caln for eight days, frop 
whence we naturally concluded, that the storm had remained at a distance. During the whole of this time we received all sorts of utensils and materials from the wreck.

On the 16 th the sea was again very boisterous, and our vessel dragged her anchor very much. The captain, Mr. Hall, and myself, who were on land, passed a very uneasy nigli, as we knew the river to have a bad bottom, consisting of pebbles, and apprehended that our vessel might experience a sumilar fate with many transports which had been oriven aground.

In the year 178\%, we were witness to a case of this kind here, with a ship arrived from Inshiga, whel was unable to enter the river at low water, and anchored off the reef The wind rising, and the sea becoming rough, the ship was driven into a shoal, and struck on the shore.

We happily escaped this danger, and embraced the first favourable wind on the 20th to put to sea, in order to sail to Kamtschatka by the way of the Kurilian islands, and spend the winter in the harbour of the Petropaulowsk. The favourable wind lasted but twenty-four hours, and was succeeded by a squall, which disturbed the sea so much that we were obliged to hawl in all the sails, except the mizen-sail, and leave the ship to the mercy of the waves.

The greater part of the people who were with us had never been to sea, and were of course continually sick from the extraordinary rocking of the vessel, which was not a little increased by the force of their imaginations; for they fancied, that every wave, which towered mountains high towards our vessel, would assuredly swallow them. Some of the sailors from Ochotsk; who had been at sea before, whispered to the others, that the storm arose from the eagle which Captain Billings had caught alive and taken with him. They accordingly entreated that it might have its liberty, and although this request was not complied with, yet the wind dropped in two days, and we steered with a favourable gale and full sails $\mathrm{S}$. E. directy towards the second $\mathrm{Ku}$ rilian island.

Although we had no idea of a new discovery in this well known sea, through which many vessels pass from Ochotsk to Kamtschatka, yet we sent a person to the top-mast to take survey of the country around, who called to us at ten o'clort in the morning, that he discovered land. We assured ourselves of the reality by means of our telescopes, and in order to remove every possible doubt, directed our course that way. After an hour's sailing, we stood in near enough to distingrish a little island, about half a mile in extent, and elevated more than a hundred fathoms above the water. It appeared to be encompassed on SARYTSCHEW.] 
all sides with lofty perpendicular rocks and clifts, concealcd under the water, and resembled a haystack at a distance.

This island, hitherto unknown, must have been very dangerous at night and in misty weather for the navigators of this ocean; and, if I conjecure rightly, the vessel which went in the September of the preceding year from Ochotsk to Kamtschatka, and was never heard of after, was lost on this shore: for a boisterous wind and a thick mist arose on the third day from the south-east, which drove the ship perhaps this way, and dashed it on the rock. Such an accident might indeed have happened on the shores of the continent or the Kurilian islands, but in that case it must have been discovered. We gave this land the name of Jonas, in honour of the saint whose feast was commemorated on this day. The latitude of this place, by my observation, was $56^{\circ} 59^{\prime}$; the depth 37 fathoms, and the bottom gravelly. The island was then fifteen miles towards the southwest of our course.

While lying in the roads I observed that the sea-birds, and particularly the mews, flew every evening from the shore to the sea southward, and returned every morning early. From whence it is fair to conclnde, that they staid for the night on the island of Jonas, or some other rocky islets lying still nearer, where they find a secure retirement, free from every molestation.

The wind continuing fair, we came in sight of the Alaid, the first of the Kurilian islands, on the twenty-seventh, lying rather sidewards, and, on that account, not properly belonging to the cluster. It consists of a single mountain, whose hoary head, eternally covered with snow, is concealed in the clouds. To us it had the appearance of a sugar-loaf, but from a south-east direction it seemed to extend itself more into a flat surface. It is said to smoke occasionally. Beyond the Alaid, the second Kurilian island breaks forth from its cloud of mist.

Unacquainted as we were with this sea, we found it prudent to remove towards night from land islands, and on the dawn of day, approached the third Kurlian island, Schirinki, the left shore of which we passed towards noon. It is about two miles in extent, and encompassed with steep rocks, consisting of tall cliffs, covered with moss. From these we were visited by a number of urilas. They all thew alternately, one after the other, very close round our ship, not less than three times, as if they would eye us with proper attention; after which they returned to their nests. This curious bird is said to be a certain indication in a storm, that land is not far off, because it never goes any distance from the shore.

From the third island we stected by the fourth, the Mamrish, shich is mountainous and rocky, into the straight between the 
second and fifth, which is called Quekotan. In the middle of this straight we were becalmed towards noon. We heaved the lead, but found 110 bottom. Its breadth, which is 27 miles; makes it one of the largest, and least diugerous among the Kurilian islands. In addition to which, it has no swampy places, and the tide is less impetuous here than at the others.

'The third and fourth Kurilian islands have neither wood nor inhabitants, but the second and fifth yield an inconsiderable number of birch-shrubs, and are thinly inhabited by a people, who, in appearance, and mode of living, resemble the Kantschadales more than the southern Kurilians. They have received the name of hairy Kurilians, from the long beards by which they are distinguished. The northern Kurilians derive their origin, if we may judge by the resemblance, from the Kamtschadales; but from whence these hairy ones are derived, it is difficnlt to decide: for scarcely any people in this quarter, either Chinese, Japanese, or, in fact, any northern nation on the shores of Asia, have any beard; except the Gilaks, living near the mouth of the Amur.

The 28 th of September was the finest day since our departure from Ochotsk. 'The sun shone till the very evening, with a warmth little inferior to that in the middle of summer. After the cold weather, which we had hitherto had for a constancy, it now seemed as if we were transported all at once from the frigid to the torrid zone, although we were only ten degrees more to the south. 'The mildness of the air, the aspect of the shore, and the glittering surface of the unruffled ocean, all inspired us with a vivacity, to which we had long been strangers. During this day we were all constantly on deck, but, usually, no one would leave the cabiu who was not on duty.

On the first of October, we descried the mountainous shore of Kamtschatka, by which we pursued our course, until we arrived off the haven of Petropaulowsk. At a distance we perceived five lofty and distinct nountains, one of which is called Wilnit-Schinskaja, and has the bay of Awatska to the right; three others lie together on the right hand, about 50 versts from the sea; of these the western, which is called Streloschnaia, has a loftier and more peaked summit than the others. The Awatskinskaia, otherwise called Goneluia, which lies adjacent to it, is volcanic, and emits fire; the third is nameless, and lower than the two others. The last, denominated Schupanowna, lies more northerly, and more remote than the rest: it appears also at a distance to be more level. Although these mountains are situated far inland, yet, on account of their extraordinary height, they are very conspicuous even above the shore, which is rather elevated. A very exact drawing of this 
view is to be found in Cook's voyage, which differs from mine only from the slight difference of position.

At the entrance of the bay of Awatska, we passed a lighthouse, erected on a lofty rocky prominence, on the left of which was an insular mountain of stone, called Staritschkow, after the name of a bird that frequents it in great abundance. The staritschkow is a bird about the size of a pigeon, with a bluish bill, and small feathers, of a bristly kind; its head is of a purple colour, having a circle of white feathers in the middle, which are thinner and longer than the rest. Its neck is black above, with white spots underneath. Its body is white, the short large feathers of its wings blackish, and the rest blue; its sides and tail black; its feet red, and trebly indigited with a web between each, and its claws black. On the little islands of. Kamtschatka they are found in vast numbers, and are caught by the Kantschadales with great facility. Besides this bird, there are also sea-parrots, mews, and urilas, the latter of which paid us a visit of curiosity as before, and then disappeared.

The entrance of the bay by the light-house, has 13 fathoms water, and a sandy bottom. The banks on both sides are peaked and stony, having occasionally windings, in and out. Not far beyond the light-house, stand three lofty isolated rocks in the form of pillars, close by each other; on which account they are denominated the Three Ribbons. Very near these pillars is a little creek called the Saline, from the salt-works which exist on its banks. On one side of the creek, lies a little stony island, called the 'Traitor's Island, from its having been the place of concealment for the ringleaders of the Kamtschadale insurrection against the Ruscians. On the other sile is a lofty rock, called the Grandmother's Rock.

The entrance into the bay extends two leagues beyond these, and terminates with the commencement of the bay itself, which is 26 leagues in extent, and loses itself in three creeks, running parallel with each other: one of which is called Tarjinskoi, the second Rakowoi, and the third forms the harbour of Petropaulowsk, which was the object of our destination. It lies more to the north of the entrance, in the middle of which is a sandbank, where the depth of the water is scarcely $1 \frac{1}{2}$ fathom. The creek itself is from six to fifteen fathoms deep, and aftords a good anchorage every where in its muddy bottom. The shore and surrounding country are mountainous, except towards the north-west, where there are some plains and low-lands. From this side aiso, flow the rivers Awatska and Paratunka, into the creek.

Towards evening we came to anchor near the harbour of $\mathrm{Pe}$ tropaulowsk, which is above a verst in circumference. On the 
west side, it is sheltered by a mountainous narrow peninsula, and on the soutls side, by a small gut of land, consisting of pebbles, and called Koschka. Between that peninsula, and Koschika, one must run into the harbour. The breadth of this straight is 40 , and the depth, from seven to nine fathoms. The bottom is muddy.

On the Koschka there are eight dwelling-houses, interspersed with several buloganen; or log-houses, and on the north shore of the haven are four, together with a wooden building for an hospital, and the store-houses built during the expedition of Commodore Behring, which are still in good condition. The number of the inhabitants is limited to eleven Kamtschadales, one ensign from the army, and 23 Kosaks. The country around the haven is mountainous, but the north and east sides have sufficient level ground for 300 houses.

\section{CHAP. X.}

ARRANGEMENTS FOR WINTERING IN PETROPAULOWST. -REMARKS ON THE FISHERY, AND THE CATTLE OF KAMSCHATKA.-JOURNEY WJTH DOGS TO THE FORTRESS OF BOLSCHERESK.-KAMTSCHADALE DANCE.PRESENT CONUITION OF THE KAMTSCHADALES.

\section{WE}

E entered the haven of Petropaulowsk on the 5 th of October, and moored our vessel by the magazines, in which all our stores and provisions were deposited. We were distributed in the dwellings, as well as the smallness of the place would admit. Mr. Billings took possession of the imperial building, which was spacious and commodious. Lieutenant Hall, Bakow, and I, took up our lodgings at no great distance, in a $\mathrm{Ko}-$ sak's house; but it was so narrow, as to hold little more than our hamocks at night. The height was proportionable to the size; for we could scarcely stand upright without striking our heads against the ceiling. The doctor and the surgeon resided in an adjoining house, and the others were accommodated on the Koschka.

For the relief of the imhabitants, we resolved on building a large jurt, a bathing-room, and a forge, on the north side of the haven. The only timber we could find for this purpose was birch, which grows very abindantly in the surrounding country. Our undertaking, which was commenced and executed in a short time, was greatly favoured by the weather, that remaines? very warm to the first of November. We had hitherto seen no snow, but what had been lying on the mountains.

'The shore, indeed, had lost the enchanting verdure of spring 
and summer, and the trees were entirely stript of their leaves; but there were some cedar or birch shrubs still remaining in the hollow windings of the mountains, that afforded us many agreeable walks, until the snow fell so heavily as to block up our passage. We had now only one narrow path in the declivity towards the Koschka, and another between the mountains torvards a lake situated 300 furlongs to the north of our dwelling-place. Near this latter path, on the right hand bank of a rivulut ruming into the haven, lie two remarkable persons, close to each other, namely, the Professor de l'Isle de la Croyére, who accompanied Commodore Behring, as astronomer, and Captain Clarke, who succeeded Captain Cook in the command. From the lake just roticed, you may, at low water, walk round the mountainous peninsula which encloses the haven on the western side, and the extent of the town will not exceed two versts; but this path is very stony and fatiguing, it is therefore little frequented, except by sportsmen, who go in search of mews, or sawkas, (Anas hiemalis), a species of ducks.

By some bedis of rock in this peninsula, we discovered green jasper marl, on which were the representations of shrubs or trees; we also found, in the crevices of the rocks, some layers of amaranth, not very large, and remarkably thin.

For some time after our arrival, there was no fresh fish to be had. In the beginning of November, we began to catch wachnas in abundance, and occasionally herrings. The wachna, $(G a-$ dus eglesimus), is a sort of stock-fish, about half a yard in length, with a roundish body, and three dorsal fins. When taken out of the water, it is perfectly of a copper colour, but soon turns quire pale. It flesh is white, but soft, and not pleasant to the taste. The roe is, however, of a tine texture, and has the best flavour. It is an inhabitant of the European Ocean, but most irequently found in Kantschatka. We were now enabled to provide ourselves with fresh and healthy food, but on the failure of this resource, we should have been compelled to live on salt provisions alone, if we had not persuaded a Kosak to sell us a cow for 6.5 rubles: the animal was not very large, and yielded but an inconsiderable quantity of meat, yet we contrived to eke it out as long as possible. The whole haven of Petropaulowsk, could not produce more than this cow and seven oxen, belouging to the crown, which had been driven hither from the fortress of Werchne-Kamtschatk for the expedition that was to have gone out, under the command of Captain Molowsky. But it was prevented by the breaking out of the Swedish war, in which this estimable officer fell, and if 1 mistake not, in the first engagement under Admiral Greig, in 1788; otherwise the Russian flag would probably have waved 14 or 15 years earlier under 
the equator. At the period of the first Kamtschatkish expedition, about 50 years ago, some horned cattle were transported hither, which we unight suppose would have considerably multiplied with proper care. It is impossible to find a place more titted for breeding cattle than Kamtschatka. It has a number of enclosures, particularly in the vicinity of Petropaulowsk, by the rivers Awatska and Paratunka, which yield an excellent pasture of tall and nutritions grass, well calculated to give the flesh a delicious flavour.

On the approach of winter, the inhabitants are busied with putting their sledges in order, and tying up their dogs, to fit them for drawing, as they are in fine weather allowed to run loose. Sledges and dogs are in general use here, both for travelling and conveyance. Mr. Hall, and I also, furnished ourselves with one, taking at first only small journies with three dogs; but growing bolder afterwards, as our skill increased, we ventured with five dogs, over the mountains, to the dwellingplace of Paratunka, 25 versts distant from Petropanlowsk.

The sledges here difier very considerably from those of Ochotsk, being shorter, smaller, lighter, and much higher. They will scarcely hold two, and are very unsteady on account of their monstrous height. In descending any hill, the utmost care and dexterity is requisite, to keep the feet and the oschtol in the proper direction; for the smallest oversight of this kind may cost a person his life, as has been the case with even experienced drivers, who have been dashed to pieces against the trees lying in the way.

The management of the dogs is no less difficult and dangerous here than at Ochotsk; for they are equally apt to become ungovernable on the scent of any animal. In order to stop them, they drive the oschtol between the front sledge of the conveyance as far into the snow as possible, and always keep the two fore dogs in a tight rein, that none may be able to run away. When the declivity of any mountain is unusually steep and daugerous, they bind birch-twigs round the bottom of the sledge, to impede its course. The cry of ko ko ko stops the dogs; aach aach drives them on; chna chua chna, turns them to the right; and uga uga uga, to the left. Hunters do not make nse of these words, for fear of frightening their game, but strike gently with the oschtol on the right side of the sledge, when they should turn to the right, and bend them down to the snow to the left, when they should go to the left. Besides the danger in this mode of travelling, it is attended with many inconveniencies. Tou must never let vour dogs go loose. If ever you are overtumed, you must rather be dragged along in the snow than leave your hold, for it is a great disgrace to lose your 
dogs, and be obliged to wade through the snow on foot; not to mention that the dogs very often entangle themselves in their harness, in which case, the driver must take off his gloves in the cold to put them to rights, and is often in danger of being soiled with their dung. The worst trick you can play a driver, is to cast a piece of jukol among his dogs, who fight for it until they are thrown into the utmost confinsion. If he be in company with others, he is thus prevented from keeping up with them, and exposed to all the inconveniencies of going behind; the principal of which is, that the dung of the other dogs is continually freezing on his sledge, and requires him every moment to clear it away with his knife. When you get to a public-house, you are not free from your dogs. The instant they are unbarnessed, they must be tied to a post. Nor can they be immediately fed, for they must wait until the sweat is dricd off. A whole or half a jukol is then given them, but the master must stand by to see that every dog gets his part, and also to drive away the crows, which are not very shy in this country. They will collect in great quantities round the dogs if not thus guarded, and snap up all their allowance.

Captain Bilings going with $\mathrm{Mr}$. Hall, the surgeon, at the close of November to the fortress of Bolscherezsk, Mr. Behring and I followed him, agreeable to his request, at the end of December. We set off with our dogs from Petropaulowsk, and proceeded by the bay of Awatska, over litrle acclivities covered with birch-wood. On the summit of one we saw a loose stone thoroughly burnt, about five yards in circumference. It appeared to have been thrown out from some volcanic mountain; but as that of Awatska, the very nearest, is certainly 40 versts distant, it is not probable for a stone of that weight to have been hurled so far on any eruption, however violent. It is a far more feasible conjecture, that the explosion formerly took place in a quarter nearer this spot. It is in fact not altogether improbable, that the place now occupied by the bay of Awatska, was formerly a volcanic mountain, which fell in and formed this harbour. It retains at least many traces of having originated from a convulsion of the earth. Seven versts from the barbour we left the above heights and desended into a plain that extends for 20 versts, and is intersected by the two rivers Awatska and Paratunka. We stopped at the Kamtschadale place, of the same name with the latter river, which lies seven versts distant from its mouth, and has a wooden church, the remains of what had been built on the expedition of commodore Behring.

From the fortress of Paratunka, the way leads up the river Awatska, where we found many otters, and discovered the traces of sables and foxes. 
The sables of this place are not esteented the best, but the Kamtschadale red foxes are superior to aty of their kind, ald are sold at remarkably high prices when they are of 'a fiery sed colour. From this particular they lave received the name of Ognenken. Besides these aumals, there are, as twe learn from the Kantschadales, wild sheep, reindeer, liearis, and wolves, in the mountains. The last are the most dangerouts, atid frequently make fierce attacks on travellers in the whiter. But the bears are so peaceable, as even to be afraill of triman beingrs, and run away at the sight of them.

After travelling three and thirty versts, we took up our inghts lodging at the little fortress of Koratchin, so called fion its having been first founded and inkabited by the Koraks. This dwelling-place was separated by 30 versts of mountainots côth try from the fortress of Natschinsk or Nitclieeken.

Two versts distant from here is a hot spring, culled Natschikinskish. We turned a little out of the road to visit this water? which, notwithstanding the severity of the cold, wids still remarkably repid, having a sulphureous smell and a bitter taste. We threw in some pieces of money, which, in a few hours, received the light grey colour of tin. The Kamtschadales make very frequent use of this spring for a bath; on which account it was paled in, in two different places, one above, at its source, for the winter, and the other below, for the summer. We wished to see the rise of this spring, but were prevented by the swainpiness of the ground from approaching sufficiently near.

Wo set off from lence before day-break, in order to reach the little fortress of Apatschinsk, 95 versts distant, in one day. Our way led over lofty mountains that stretch in a continued chain from the interior of Kamtschatka to the shore; where they are lost in rocky declivities. Apatschinsk lies on the river Bolschaja, as you descend froin these mountains. From here to the fortress of Bolscherezsk were onily 40 versts, which we went by a direct and even road in less than four hours.

The fortress of Bolscherezsk, situated on the banks of the Bolschaja, has a church and thirfy habitations. Its inhabitants consist principally of Kosaks, with a few merchants and citizens. Before the advancement of the fortress Nishne-Kamtschatzsk to the rank of a town, the first magistrate of Kamtschatka made this his place of residence; but now a serjeant is commander of the fortress. The Kosaks here are much more opulent than those of Petropaulowsk, almost all of thein having their cattle and a good domestic economy. Their gardens are stocked with excellent turnips and potatoes. For the introduction of the latter vegetable they are indebted to counsellor Reineké, the former commander of Kamtschatka.

All the inhabitints here are usually dressed like the KamtSARYTSCHEW.] 
schadales, in narkas and kamlegas. The former, are the skins of reindeer, cut into shirts; and the latter are skins of any kind, stripped of their hair, and made quite pliant. On holidays, the women wear a sort of silk gown of an old Russian shape, which was fashionable 60 years ago. They have also a speckled silk handkerchief about their heads.

In the first days of the new year, the inhabitants assembled every evening for the purpose of dancing. The women understood Russian dances very well, and what was still more surprising, could dance in the Polish fashion, and very passably even à la Grecque. The music consisted of three fiddles, played by Kosaks.

I did not see the Kamtschadale dance here, but among the Kosaks of Petropaulowsk, who give it the preference, it is so indecent, that every modest woman would blush to be a spectator, much more a partner in it. A woman makes the commencement by stepping forward into the middle of the Isba, and holding a cloth spread out before her in a transverse direction. She shifts her feet slowly, making a variety of motions with her hands, head, and body. Her head sinks alternately on one shoulder or the other, on her back or on her breast. She then at length advances to a man, and renews this gesticulation close before him, which implies as much as soliciting his hand to the dance. He accordingly takes hold of the cloth in the same manner, and rising from his seat, they both commence the distortion of all their limbs together. The woman turns every now and then away from the man, but returns to him instantly again, sinking gradually upon her knees, and then bending herself backward with a similar gesticulation; the man also in the mean time falling down and reclining himself over her, the dance is concluded with the most obscene gestures. While it lasts, both dancers and spectators all sing to one song, consisting of the words an-kelle, an-kaget, incessantly repeated: but they have a variety of such monotonous ditties, adapted to the same species of dancing. In some of their dances, they imitate birds and beasts; the man for example representing the male, and the woman the female bear; and sometimes there is a company of these jmitators, who amuse themselves together, either in running like partridges, gabbling like geese, or in aping some other animal.

After a fortnight's stay at Bolscherezsk, Mr. Billings and Mr. Hall went to Nishne-Kamtschatsk, while Mr. Behring and I returned to Petropaulowsk, which we reached in five days.

On our journey thither and back, we experienced the most friendly treatment from the Kamtschadales, who not only enterzained us with the utmost cordiality, but made us liberal presents of partridges, fresh fish, frozen keta, jukol, berries, and roots, 
which are collected in great quantities from the mouse-holes, and form one of their principal aliments.

In autumn, they go into the fields in search of these roots, and as soon as they find hollow ground, by stamping, they dig down, and lay open the store-rooms of these animals. They do not, however, empty them entirely, but leave the mice a third at least of their provision, probably with a view of not driving away such useful creatures. They terrify each other, indeed, with the saying, that the mouse which is deprived of all its sustenance, will hang itself in despair on the next tree; a tale which may perhaps have originated in the circumstance of a mouse having been entangled by accident in the branches of a tree, and having hung there till it died.

On comparing the present condition of the Kamtschadales, and their way of living, with Krascheninikow's description of them, we find them to have undergone a remarkable change. They have now almost entirely renounced their former superstitious customs, and submitted to baptism. Jurts, or subterraneous dwellings, are now vanished, and their place is every where supplied by Russian isbas. The female Kamtschadales have a dress for holidays very similar to those of the female Kosaks, for they wear stomachers and petticoats, and bind a handkerchief round their heads. The abundance of fish, and the facility with which they prosure a subsistence, now grown pleasant by habit, are probably the causes why they make no exertions in agriculture, or the breeding of cattle. It is much more remarkable, that their long and close intercourse with the Russians should not have given them a little more worldly wisdom; for they continue to this moment to barter their sables and foxes skins for the merest trifles. With this deficiency in cultivation, they retain, however, their good qualities, and are jusţ as good-hearted, sincere, peaceable, obliging, and hospitable as before. Their prominent faults are unclęanliness and idleness. Thieving is very rare, and murder still more rare. Some travellers charge them with the vice of drunkenness, bnt I cannot confirm this with my testimony; whatever bad exceptions there may be, they cannot serve as a general rule.

Notwithstanding the Kamtschadales have renounced most of their former superstitions, they still retain a firm belief in the supernatural powers of the schamans. A Kosak once profited by this credulity to regain his stolen property in a very ingenious manner. While on a journey with several Kamtschadales, he had some of his tobacco stolen from him, and, after questioning every individual separately, he was unable to discover who was the thief. He accordingly took some sticks, and waking them of equal lengths, gave each of them one, with the assurance, that the stick of the thief would infallibly grow longer by the 
powrex, of schamanury. This unpleasant intelligence had suct an effect on the imagination of the thief, that he actually conceited that his sticl did increase in length, and thought to relieve himself from this diemma by breaking a piece off. The next morning, every Kamtschadale carying back his stick, the thief was instintly disconered. He was now obliged to confess the theft, and make restoration. His apology was, that all his own tobacco being gone, he had no money to buy more, and could not dispense with this necessary. Tobacco was remarkably dear at that time in Wamtschatka, a single pound costing a hundred rubles; and yet the inhabitants of this place sacrificed every thing to the indiggence of their passion for this intoxicating herb. Its ordinary price on a fresh supply is only two rubles and a half.

Tobacco is one of the most lucrative branches of trade in these parts, and always fnds a ready sale; for there is not a tribe or nation having any intercourse with the Russians, which does not smoke, chew, and take snuff. The Burats, Jakuts, Koraks, Jakugirens, and Tschukschens, like the strong Tscherkapian tobacco, and are not foud of that which grows in the country of Iriuts. They smoke it with a mixture of half saw-dust; but the Kamtschadales and Aleutians only chew tobacco and take siuff.

\section{CHAP.XI.}

WINTER OCCUPATION ON' BOARD THE SHIP.D-TREML BLTNGS OF THE EARTH, AND ERUPTION OF THE KLUTSCHEWISH CRATER.— - SURVY AMONG THE MEN.EQUIPMENT OF THE VESSEL. - DESCRIPTION OF THE BAY AWATSKA.- HINTS ON THE FACILITY OF ESTABLISHING A TRADE HOM KAMTSCHATKA TO THE EAST INDIES.

T

HE winter afforded us a good opportunity for completing what had remained untinished at Ochotsk. We built another cutter with six oars of alder-wood, fetched from the banks of the Paratunka, at thirty ver ts distance. We had, indeed, birchwood in the vicinity of the harbour, which served for many useful purposes, but was not close enough for vessels of any magnitude. For stallops and other small craft, however, this wood is in general use here, and always found to answer. The doublebuilt shallop of Kamtschatkish birch, which was used on the nirst expedicioin, not only lasted the time required, but was afterwarts employed as a victualling barge from Ochotsk to Kamtschatia. Judging from the richness of the soil, I should be inclined to think, that oaks might be introduced here by acorns, and would thive remarkably well.

On the 55 th of Eebruary, we observed an evident agitation of the earth, which is very frequeut and strong, owing to..jts 
Weximity with the volcanic montain of Awatska; but this was the first of the kind during our stay here. This mountain was likewise perfectly quiet, and emitted nothing but snoke; while the Wrlutschewish summit, on the other hand, sent forth, in January, Alames, stones, lava, and a quantity of black sand, witls which the whole circumiacent country was covered.

Captain Billings returned from Nisne-Kamtschatsk at the ent of March. By the midale of April, our cutter was in a suffcient state of readiness to receive its tackling and other appurtenances. About this time, the bay of Awatska became perfectly free from the ice'which had collected near its banks during the winter; but the sideward bays, the Rakowoi, Targinskoi, and Petropaulowsk harbours," continued under ice until the 1st of May.

Many of our people were afficted with the scurvy this winter, owing to the want of proper mutriment. On the approach of spring, the evil gained ground ather than otherwise; but as soon as they had an opportumity of getting fresh fish, they mended. daily, so that in the begiuning of May they were almost entirely recovered. The malmas, hesrings, kambalas, and keuschens, now came in shoals into the rivers, and the green of a species of garlic, began to make its appearance.

Our vessel being perfectly ready for sailing on the Ist of May, our people were all assembled on board. We brought it out of the habour and anchored at its mouth, in expectation of a favourable wind for running out. I sailed about in the mean time for the purpose of surveying the bay of Awatska, and the two side bays. Pakowoi is three leagues long, and half a league broad; its depth is from 6 to 13 fathoms, and its bottom is muddy. The other, Targinskoi, situated on the not th-west side of the Awatska bay, is tive miles in length, and half a mile in breadth. Its north-east bank consists of a narrow mountainous promontory, which separates it from the Aratska bay. It has 13 fathom of water in the middle, which diminishes as you proceed downwards. Its bottom is likewise muddy.

The two rivers, Awatska and Paratunka, flow into the northern part of Awatskish bay; after ruming down the mountains through several low lands. From the mouth of these rivers upwards, there is a dry. place half a mile broad; but elsewhere, the whole bay is tolerably deep, and would adinit of large vessels to lie at anchor in 14 fathoms water. 'The bottom in the deepest places is muddy, but in the shallower part is sandy.

This and the other bays would serve as good anchorng grounds for the most numerous fleet." It is 'truly lainevitable, that a harbour so well formed by nature, should remain unused. In a short time it might become an important station, if our merchants paid due attention to the advanges they could derive from their trade with China; Japan, and the East Indies. 
The bay of Awatska might then be the principal rendezvous for all vessels going on the chase, to the Islands and America, or trading to the East Indies; for on all the shores belonging to Russia in this quarter, there is not a securer and more commodious place for the mooring of ships. In this case it would be necessary to build warehouses for the merchandise.

With regard to the commodities that might constitute our trade with China and Japan, the products of these parts, independent of those from Russia, would amply suffice, as seabeavers, sea-lions, otters, foxes, minevers, and above all the fangs of the walrus or river-horse. Bat the most important commerce might be carried on with train-oil and whalebone, whenever proper arrangements could be made for catching the whales which frequent these seas in vast numbers. Not to mention, that the shoals of other fish which are to be found in Kamtschatka, would prove no inconsiderable source of advantage when salted and dried.

The conveyance of East India products into the interior of Russia by the bay of Awatska, might be greatly facilitated by carrying them from hence in small craft to the Aldomish bay, and then by the river Maia to the Jakutsk.

If in addition to the advantages resulting from this trade, a colony were raised here, agriculture extended, the breeding of cattle encouraged, and all sorts of manufactures established, Kamtschatka would in a short time rival the greatest part of Europe in affuence and cultivation. 'The climate is temperate, and the soil prolific in whatever is essential for living. Agriculture has been attended to with tolerable success for some time on the river Kamtschatka by the upper fortress, and in the village of Klutschewsk, which is inhabited by Russian peasants; but with so small a number of labourers the progress is not visible.

Provisions for the military are imported from Ochotsk. A pood of rye-flower (abont forty pounds), costs the government 3 dollars 75 kopeks. The ischetwerik (360 pounds) of buckwheat and barley grits, six rubles. Potatoes, which have been introduced here about 10 years, thrive very well, and increase particularly in Bolscherezsk, where the greatest care is taken of them. It is also very certain, that flax and linen might be produced here, which would be cheaper than what is imported, the coarsest of which is sold at 70 kopeks, or a dollar, (3s. 6d.) a yard.

The spirits here are extracted from a sweet herb, and are equally offensive both in taste and smell. They cost 40 rubles a pail.

Copper money is scarcely known in Kamtschatka, silver coin only being in use; but small notes or assignations are beginning to get introduced.

END OF VOL. I. OF SARXTSCHEW'S TRAYELS. 


\section{ACCOUNT}

OF A.

\section{VOYAGE OF DISCOVERY}

TO THE NORTH-EAST OF

\section{SIBERIA,}

\section{THE FROZEN OCEAN,}

AND THE

NORTH-EAST SEA.

BY

GAWRILA SARYTSCHEW,

RUSSIAN IMPERIAL MAJOR-GENERAL TO THE EXPEDITION。

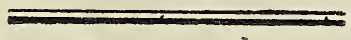

VOL. II.

TRANSLATED FROM THE RUSSIAN, AND EMBELLISHED WITH ENGRAVINGS.

LONDON:

Frinted For RICHARD PHILLIPS, 6, BRIDGe STREeT, B L A C K R I A R S,

By J. G. Barnard, 57, Snoze-hill. 


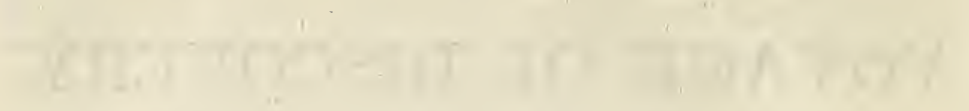




\section{A VOYAGE OF DISCOVERY}

To

SIBERTA, \&c.

CHAP. I.

DEPARTURE PROM THE BAY OF AWATSCHA OR THE ISLAND OF UNALASCHKA. - DESCRIPTION OF THE BAY OF BOBROWIA.-REMARKS ON THE ALEUTIANS。

A Favourable gale springing up on the 29 th of May, we stood out of the bay Awatscha in a south-easterly direction. On the 10th we discovered a plank floating on the sea, that appeared to have been torn from some vessel. Agreeable to our instructions, we should have steered along the chain of Aleutian islands towards America, and taken a map of this coast; but a thick mist coming on immediately after our departure out of the bay, it was unanimously resolved not to lose our time in a minute survey of every islard, but to keep in close to the south side of those that were less obscure, and bend our course directly to America.

On the 16 th we were surrounded by a great quantity of floating logs of wood and sea-wort. Many sorts of marine birds in great abundance kept hovering around us, and one of them, of the duck species, even lit on our vessel. We were now in north latitude $50^{\circ} 39^{\prime}$, and longitude $169^{\circ} 64^{\prime}$ from Greenwich, not more than 180 ltalian miles distant from the island of Atta. We usually calculated by Italian miles, 60 of which go to a degree.

Our people on setting out were all tolerably recovered from the scurvy, with which they had been generally afflicted during the winter, but now they felt an increasing debility as they advanced farther into the open sea. 'The want of proper diet likewise contributed to renew the disease which had been completely removed. Salt meat was almost our only food, having been unable to lay in any stock of fresh provisions at Kamtschatka, where all sorts of animals, both tame and 
wild, are very rare, and those who possess will not part with their little stock at any rate.

Though the wind was constantly favourable, yet the incessans mist impeded our progress for many days. We met with nothing remarkable till the $23 \mathrm{~d}$, when we discovered land, which proved, on our approach, to be Amtschitka, or one of the Rat Islands. From what we could distinguish through the mist, its shores appeared to be naked and not very elevated, but sometimes mountainous. At no great distance from thence we descried the island properly called the Rat Island, which derives its name from the circumstances of its abounding with rats. As there were formerly none of these animals here, it is surmised that they made their escape to the shore out of some Japan vessel, stranded on the coats. The eastern side of Amtschitka is more mountainous than the western, forming a rocky declivity from south-west to north-west. On a cursory view we estimated its length at 30 Italian miles.

On the 25th, the wind became so strong that we were obliged to carry less sail. Towards evening we stood to the north, and on the following day to the north-west; and, although still enveloped in mist, we could distinguish the high snowy mountains on the islands Adach and Jagitka.

On the 28th, the wind and mist abating, we perceived the island Amilja, and the lofty mountains Atcha contiguous to it to the west, both belonging to the Andiejenow Islands. We conceived our latitude to this time to be $41^{\circ} 54^{\prime}$, and our longitude $187^{\circ} 67$; the western point of Amilja being northwest $52^{\circ} 30^{\prime}$ at a distance of 15 miles. We sailed the whole day in a parallel line with the island about 8 miles distant. It is naked, mountainous, long, and marrow; being from west to east 44 miles in extent. Its eastern extremity is bounded by high and steep rocks. Its centre contains a number of hills. Its population does not exceed 60 persons.

In the evening we came in sight of the mountainous island of Seguam, about 24 miles in extent, lying 22 miles north-east by east of Amilja. It is uninhabited, and is said formerly to have had a volcanic mountain.

On the morning of the 29 th we passed the island Amuchta at a distance of 6 miles. It is about 27 miles in extent, and is said to have a volcano. About 12 miles from Amuchta we passed Techugagar, an island 12 miles long and 5 miles: broad.

On the 30th, we fell in with the four volcanic islands, which take their names from the four craters which they contain. They lie contiguous to each other, and bear distinct names. 
That to the south-west, is called Ulaga; that to the northeast, Tschiginsk; that to the north-west, Tana; and that to the south-east, Chagamil. 'The two first are the largest, and about twenty miles in circumference.

The latter islands appeared to the north-north-west about 10 miles distant. They are said to be volcanic, and were once inhabited. At noon our latitude was $52^{\circ} 34^{\prime}$. Towards evening we discovered the island of Umnack, one of the Fox islands, which extend in an unbroken range to North America. They rlerive their name from the number of black, darkbrown, and red foxes, with which they abound; but the white species found in all the islands near Kamtschatka, are no where to be met with here. Ten miles from the southwestem point of Umnak, on casting the lead, we found 55 fathoms water, on a bed of black gravel. We drifted all night, and were carried by the stream 13 miles to the south-southwest.

The island Umnak is level on its western side, but elevated towards the noth-east. It extends as far as the strait which separates it from Unalaschka, and terminates with mountains; several of which, rising above the others, are volcanic, and crowned with eternal snow. It stretches, from south-west to north-east, 55 miles in length. The strait between Umnak

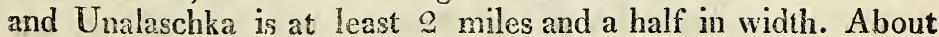
30 versts from the strait, and about 7 miles from Umnak, are two rocks, surrounded by water; whice, on the 31 st of May, lay five miles distant toward the nort-ivest. We were then in latitude $52^{\circ} 49^{\prime}$; and longitude $192^{\circ} 45^{\prime}$.

On the 1st of June, we found ourselves in the latitude of $52 \circ 53^{\prime}$, and a longitude $193^{\circ} 44^{\prime}$; the southern point of Unalaschka being 25 miles distant. From this point the shore gradually rises to the north-east into a mountain.

On the $3 d$ we were off the island Spirkin separated to the east from Unalaschka by a strait abont a mile in widath. Towards noon we estimated the latitude at $53^{\circ} 44^{\prime}$, and the longitude at $195^{\circ} 9^{\prime}$. As the form of the island Unalaschka has been accurately defined by many observations of Captain Cook, we that during the 25 days of our sailing from Petropatslonsk we had deviated 50 miles out of our course towards the east.

In the forenoon seven Aleutians put off from Unalaschka in their single-seated baidar, and came up to our ship. Two of them, who spoke tolerably good Russian, offered to conduct us to a commodious anchoring-place.

Suon after a large baidar, covered with leather, came along 
side of us, containing a Russian hunter and eight rowers, who had been rowing about in search of the drifted wood for fuel. 'The Russians told us they came from the ships Bartholomew and Barnabas, belonging to the merchants Panow and Company, which were at present lying at anchor in the strait of Issanozk; but that he himself was left at Unalaschka as the master of a baidar, for the purpose of catching wild animals.

In the afternoon, as we were nearly becalmed, we hoisted out our boat, and towed the ship into the strait between Spirkin and Kigalga. Near the entrance of the strait are two rocks, which tower out of the water; they lie close to each other, and are about 2 miles and a half distant from the island Kigalgal, towards 180, $\frac{1}{2}$. These are the rocks betwcen which Captain Cook lost himself during a fog, and to which, owing to his providential escape, he gave the name of Cape Providence.

In the evening, with the help of towing, and a good tide, we got round the northern promontory of Spirkin, anchoring, near the shore at a little distance from an Aleutian village, in the joyful expectation of meeting with some fresh provisions for the recovery of our sick.

From our anchoring station, a large bay extended southwest into the interior of the island Unalaschka, which is called Beaver-bay. Agreeable to the desire of our commander, we went on the following day with Doctor Merk, in a baidar, to examine the bay, and took with us provisions for seven days. We bent our course to the south-west, by the shore of the island Spirkin, within the bay, which is not so steep as on the south-eastern side; for here the extremities only of the cape terminate in rocky aeclivities, whereas, on the contrary side, the declivities are excessively steep. The internal part of the island affords four tolerable lakes, at no great distance from and nearly opposite to each other. The water, which in the middle is 50 fathoms, becomes gradually more shallow towards the shore. We chose one of these bays for our night's station, and found, when the water retired in the evening, a number of muscles on the strand, containing several small pearls. The next morning we were obliged to remain till nine, in order to repair our baidars, the leather of which had been considerably injured by the sharp stones jutting out from the shore.

Mr. Merk having lauded to collect plants, 1 proceeded onward by myself in my examination, taking a minute survey of the strait before-mentioned, which separates Spirkin from Unalaschka. It is a mile in breadth, and about 50 fathoms in depth; extending to the south-east, for $2 \frac{1}{2}$ miles, to the side of llmudichtchit, which penetrates, for three miles, into 
the interior of Unalaschka. Farther on, it is narrower by one half, and the shore by no means so steep. Its depth is from 20 to 25 fathoms, and the bottom is composed of a sand mixed with shells. In the middle of this strait, and particularly towards the right bank, there are many concealed rocks, and one, which at its termination rises considerably above the water. In the vicinity of these rocks the water is 10 fathoms deep. The hidden part of the large one is covered with an incrustation of coral.

On my return late in the evening, I found that $\mathrm{Mr}$. Merk had collected a vast number of plants, and that our hunters had shot two woodcocks, besides finding a nest full of eggs, which afforded us a comfortable supper. We did not observe many birds on shore, but the few we saw were chiefly whiteheaded eagles, and some small birds of the finch species; with whose red feathers the Aleutians adorn themselves.

On the 6th, we pursued our rout along the shore of the Beaver's-bay, passing five other different bays. The first of them, named Amugul, has an island in its centre ; and the second Taneska, has four such islets. All these bays run three or four miles into the country, and are supplied with streams of fresh water from the mountains; their depth, in the middle, being 50 fathoms, and at the sides much less. From the last of these bays, called Kikukala, we passed over to the opposite . shore as far as the entrance into Beaver's-bay, and lay to, for the night, close by a sinall cataract that descended from a lofty mountain.

On the 7th we passed the bay of Unytschaba, and finding another bay at noon, named Ugadaga, we ran into it for the purpose of taking our dinner. Here, as the Alentians informed us, we were not very distant from Captain's-haven, beyond the mountains, which lad received its name from Captain Lewaschew's having wintered there. Mr. Merk and I being both desirous of visiting it, we immediately resolved to repair to the spot. For two miles we were obliged to ascend the steep mountains, until we gained the summit of the high chain which encompasses the whole island, and to which the crater on the northern side belongs. These mountains are covered from the foot half way up with moss and grass: higher up they are quite barren, terminating at the summit in naked rock. In the vallies on the banks of the lakes and rivulets, a few alders and small bushes are occasionally to be met with. On the summit of the mountain which we ascended we found two lakes of fresh vater; at the bottom of which we perceived some chalybeate ochre, with which the swampy places appeared to be filled. From thence we passed over some inferior mountains, until, 
by a retrograde descent of about five miles, we reached the Aleutian village of Illuluk.

Illuluk lies on the eastern part of Captain's-bay, at the mouth of a brook. It contains four large jurts, or huts, constructed of mud, and logs of wood, which are driven hither by the currents of the sea. They are covered with grass and mud, and instead of a door have an opening, which is too low to enter without stooping. From this opening you ascend by a beam, that serves for stairs, into the interior of the hut; where, close by the walls, divisions are set apart for each family, and the floors are covered with rush-mats, which serve for beds. Every female occupies a distinct division, and is mostly busied in making mats, sacks, or baskets, which task she executes with amazing dexterity. These baskets, \&c. are made of the longest blades of grass previously dried, and for the finer works, split into slips. In this process, she uses no other instrument but her fingers: with the nail of her fore-finger, which she suffers to grow to a great length, until it is as sharp as a lancet, she not only parts the blades of grass, but also the sinews of animals, which she twists with her fingers alone into a beautifully fine and even thread for sewing their clothes. Their needles they make of the bones of fish, large or small as the work requires, and fasten their thread to them by tying. Whenever they get a steel needle, they immediately break off the eye, and rub it on the edge of a stone, till they have made a notch, where they can tie the thread in their usual way.

It is worthy of remark, that the stomachers of these women are as beautifully shaped and decorated, as if they had been the workmanship of a European embroiderer. The stomacher is made of the skin of a bird's neck, stretched and prepared for the purpose, and ornamented with silk, or the hair of geats and horses interwoven with that of the reindeer, which latter appears like rows of small pearls. In a similar manner they decorate the holiday dresses, girdles, and caps of their husbands. 'The dress of the men resembles a waggoner's frock, with a high round collar of elk's skin; it is neatly ornamented with goats hair, bordered with a strip of sea-bear's skin.

The common dress of the women differs but little from that of the men. It has a standing collar, about two inches broad, enamelled in various patterns. The front of the dress, and the opening of the arms, is trimmed with a row of pearls or coral. Their festival dress is similar in shape, but more enamelled, and bordered with rows of coral, bird's beaks, and goat's hair. When they go on the water, they draw over their common dress another, made of the entrails of animals sewed together, 


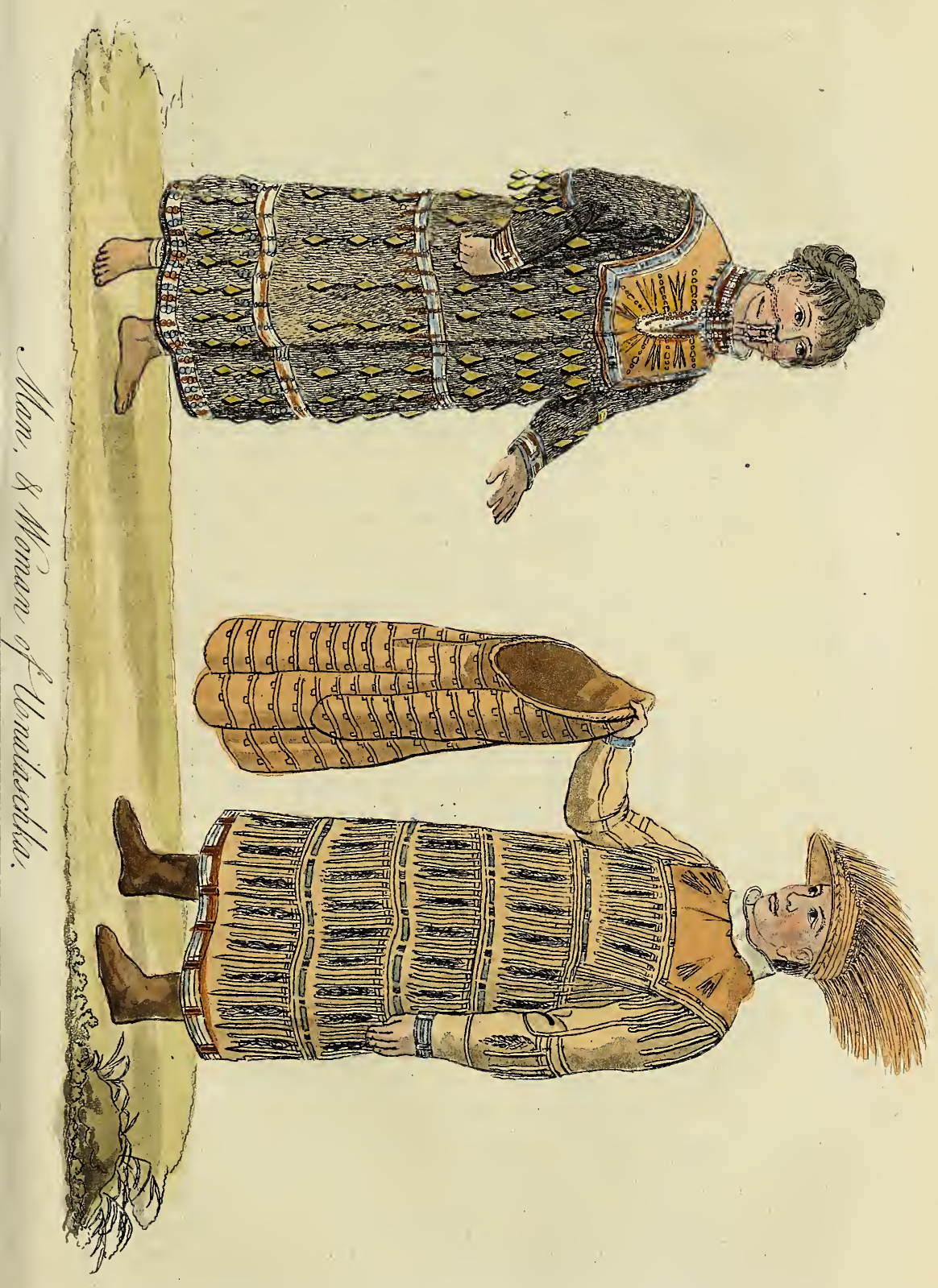



and wear trowsers, and boots made of the skin of the sea-lion's neck. On their heads they wear a wooden hat, from which descends an ornament of coral and hair.

When one of these Aleutians thus arrayed is seated in his baidar, there is something majestic in his appearance; but when he rises, he cuts a deplorable figure; and when he walks, he looks still more wretchedly, being disabled by continual sitting from straightening his feet or knees. Their countenarces are not unpleasing, though rather wild, and their features uniform with the esception of the bone of the forehead, which projects too much over the eyes. Their hair is black and stubborn, but they are for the most part beardless. I saw only one old man who had a few hairs scattered on his chin.

The men leave their faces as nature has formed them, but the vanity of the females leads them to disfigure theirs in a variety of ways. They perforate them in lines, from the nostrils to the ears, and rub in charcoal, which produces, when the wound is healed, a bluish furrow. Another is formed in the same manner, from the upper lip to the chin. They pierce the cartilage of the nose, and wear long pendant ornaments of amber, coral, and enamel. Enamel they receive from the Russians, and amber from the Americans of Alaksa, both of which are in great estimation. They also pierce two holes in the hollow of the upper lip, in which they wear long thin bones: round the edges of their ears they sew ornaments of blue or white enamel.

There are, however, many-females who, out of complaisance to the Russians (with whom they frequently intermarry), abstain from this barbarous custom. Many who are the offspring of these marriages have perfectly fair European complexions, and red hair, and would in my opinion be esteemed uncommon beauties even in Earope. They cut the hair off the forepart of the head, and bind the remainder into a knot at the back part. They wear no covering on the feet or head, nor any other clothing than the vest before described.

In the evening, some of these people returned from the chace, and informed us, that they had killed a small whale, on the westem point of Captain's bay. As we passed the night there, Mr. Merk set off on foot the next morning to see this fish, and I preferring to go by water, took a baidar with two other persons. The day being perfectly serene, I felt no apprehensions at venturing myself in this little bark upon the bay, although it was only 23 feet long, one and a half broad, and eight deep. It was entirely covered with skins, in which openings were left for each person to cuter. I sat in the midile, one Aleutian at the head, and another at the stern. We were also attended by

SARYTSCHEW, VOL. 21.] 
four others, in separate baidars. 'To one of them $I$ gave the lead to sound the depth, where I conceived it necessary, while I myself kept the compass, and where it was practicable I went on shore. By this means, I effected a complete survey of Captains-haven in one day. Its entrance is divided by the mountainous island Amaknak into two straits, which run into it; that to the east, is about a mile in width, and in the middle of the entrance, from 22 to 29 fathoms deep, although a little more to the north-east towards the main sea, the water is more than a hundred fathoms deep. Nearer the intemal part of the haven, towards the south, the depth and ground are very various. At first the water decreases from 23 to 10 fathoms, the ground consisting of fine sand: at the distance of about three cables, the depth is from 9 to 10 fathoms, and the ground stony; after this, the depth increases to 25 fathoms, with a muddy bottom. A quarter of a mile from the entrance near the island, is the gulf of Udachta, about half a mile broad, and, on the side next the ocean, bordered with a strong: bank. The water in its centre is from 17 to 20 fathoms deep, and its bottom muddy. From this bay to the distance of two. miles, as far as the village of llluluk, is a good anchoring-place, with 8 or 9 fathoms water, and a muddy bottom. Here the road becomes disproportionably narow, curving out to the west, and penetrating into the island of Amaknak, which: shelters it from wind and weather. On entering the straits. care must be taken to run in on the left side of some masses of stone, which rise above the water. They are about 60 fathoms: distant from the shore, but the water here is not more than. from 5 to 8 fathous, while that on the right side, is at most only 3 fathoms and a half. About a nile and half beyond the village, the ishand of Amaknak terminates, and you enter the inner part of Captain's-bay. It is about a mile broad, but towards the south extends three miles and a half, having in the centre 50 fathoms water, which becomes shallower as you proceed, the ground being always muddy. On the main shore, a brook descends from the mountains, to the right of which lie four small islands. It was behind these islands that Captain. Laweschew lay a winter at anchor.

My Alentians pointed out to me a hillock on the shore, which they said was the spot: where the jurts for the crew stood; but at present no vestige of a human abode remained, except a dccayed wooden eross, on which, with much difficulty, I deciphered the following inscription:-_ Captain Laweschew here passed the winter of $1706-9$, wh his ships." The proper and securest entraice to Captain's-haven, or bay, is at the sonthem point of the islant of Amaknak, on its right side from the. 
viestern bay or strait, which is 200 fathoms wide, and as wide again as the eastern. In the middle it is so deep, that a line of 50 fathoms will not reach the bottom. At its entrance from the ocean, lies, on a gralually sloping shore, the village of Pestrakowo; and on the left, adjoining the island of Amaknaky is situated the isle of Uknodak, which is not more than a mile in circumference. The water between these islands is from 7 to 16 fathoms deep, with a sandy bottom.

It was late in the evening before I returned from the execution of my task to the village of Hluluk, where $\mathbb{l}$ fornd boctor Merk, with several Aleutians from the neighbouring villages, assembled to await my arrival. I had received instructions to make particular enquiries concerning the improper conduct of some Russian hunters towards the islanders two years before. From the accounts given to the governor, by Serjeant Builow, who accompanied the hunters for collecting the japak, it appeared, that this spot had been the theatre of many oppressions. The serjeant had resided with these people, and taken down in his day-book an account of their grievances, which, on his return, he delivered in to the commander. Accordingly, the governor-general of Irkutsk had commissioned Captain Billings to ascertain the facts. Having found all strictly true, I assured these islanders, that their oppressors would be severely punished for their conduct, and used every exertion to convince them that our august empress wished for nothing so much as their happiness, having strictly prohibited every disorderly proceeding; This circumstance of the Russian hunters, reminds me of the following passage, in a Voyage published by Mr. Sauer, secretary to Captain Billings, where speaking of Captain Coxe, an Englishman, meeting with some Russian hunters, and making some presents to the steersman Pribylofi, he observes, in the 16 th chap. "Nothing in the world can astonish a Russian more than a disinterested liberality, or kindness, without some prospect of future benefit : greatness of soul is applied to every man who is just, and grants his servants some few indulgences; every thing beyond this is called folly, and is sure to be imposed upon; nor have they any sentiment of feeling, except it be excited by blows. Taking this for the ruling character of the Russian hmonters, it will be easy to conceive the astonishment of Pribyloff and lis companions, at the liberality of Mr. Coxe." From the unqualitied terms in the beginning of this quotation, many might be led to judge harshly of the whole Russian nation. It is, however, evident from the context, that he means only to apply it to the hunters, which is, however, done in much too general a manner. There are no doubt, both in Russia and lingland, and all other countries, indivi- 
duals, particularly among the poorer classes, who are devoid of the finer feelings of exalted benevolence and generosity, and may be more easily affected by fear, than by honour or integrity. Where then is the wonder, if such be also found among the Russian hunters, when we find them among those who call themselves philosophers. But notwithstanding all that has been said by different persons, to the discredit of this class of men, I cannot refrain from observing, that these hunters, who go out with merchantmen to the Eastern Ocean, are mostly persons who, from a state of affluence, are reduced by their own extravagance, or by unavoidable misfortunes, to the necessity of seeking a precarious living, at a distance from their former abode. Ochotsk is immensely remote from Russia, and the travelling by land no less toilsome than that by sea from thence to America, which must be undertaken in vessels altogether unfitted, either in bulk or tackling, for such a distance, and devoid of every comiort and convenience; whence it may be fairly concluded, that few, except persons in desperate or low circumstances, will offer their services, and that among such an assemblage of people many will be found to abuse the power vested in their hands. The hunters with whom Serjeant Builow was in company, had selected one from anong themselves to be their leader, to whose orders they paid not the slightest deference. According to the account of the serjeant, these bunters compelled the islanders to procure beasts and skins for them, which they took without making any remuneration. This trade is, however, at present placed on a better footing; some naval officers having, undertaken the command of the vessels destined for America, from which we may naturally expect the preservation of good order and discipline on the part of the Russians, and a renewal of confidence on that of the islanders: so that the trade will in future flourish on the sure basis of mutual interest."

On the moming of the 9th of June, ve left the haven, and returning at noon to our baidars in the Beaver-bay, pursued our rout after dinner along the north-western shore of the bay towards the entrance. Having made almost three miles, we came to the gulf of Gamgck, directly opposite to Sperkin's-strait. Our Alcutians informed-us, that an English merchantman had anchored here the year before. The gulf penetrates a mile and half inwards. At the entrance, it is a mile broad, and in the midd!e 50 fathoms deep, but farther on it shallows to less than 5 fathoms, the bottom being muddy, with sand occasionally interspersed. About three miles from the gulf, we arrived at the village of Utschuguy, situated on a winding of the shore, near a stream which descends from the 
mountains: beyond this, the shore of the bay for three miles is covered with cliffs, and terminates with projecting rocks.

On the 10th, I concluded my sketch of the Beaver-bay, and returned to the Slawa Rossu, which I found ready for sea, and only waiting a favourable wind.

While we lay at anchor, we were supplied by our Aleutians with a sufficiency of stock-ish and roaches for the whole crew. The hunters whom we had sent to the island Kekalga, brought us also a variety of sea-fowl, and a particular sort of blackheaded geese, which Dr. Merk called Canadian. On one of. the cliffs which rises out of the water, at a small distance from land, they likewise killed a sea-lion : a creature so called, as it seems, from the colour of their hair, and a sort of bushy mane on the necks of the males, which are nearly three feet long, and at the breast proportionably stout, but from thence to the tail becoming gradually smaller and more pointed. The head is round and bearded; and the nostrils extend very much when they are irritated. They are found in troops on the islands of the Pacific Ocean, and have frequent contests together, about their dens and females. They live on fish and amphibious animals. The people of Kamtschatka, who shoot them with arrows when they are asleep, cure their flesh and fat for food, and their skins either for clothing or covering their snowshoes.

In the mean time, our priest baptized ninety-two islanders at their own request; but not understanding their language, he could not properly instruct them in their new reiigion, into which they were initiated, by the simple ceremony of the sacrament.

For a whole week, we were detainer by nothing but con trary winds.

CHAP. II.

PQPARTURE FROM UNALASCHKA FOR KADJAK.-DESCRIPTION OF THE ALEUTIAN ISLANDS.-THE ISLAND OF KADJAK, AND ITS INHABITANTS.

O $\mathrm{N}$ the 17 th of June, I accompanied Captain Billings to the village Utschujug, on the other side of the Otters-bay, where the Russian inhabitants had heated the baths for us. They are the only persons having such baths, which they have constructed ont of subterraneous caves, and lined with walls pne brick thick.

Being informed by the Aleutians, that at no great distance peyond this bay we should come to that in which Captain 
Cook had lain with his vessels, we wished to have visited the spot, and had no sooner commenced our excursion, than we discovered our ship to be under sail, and were obiiged to relinquish our design. The wind and weather which had been so favourable, as to induce Captain Hall to weigh anchor in our absence, was very soon succeeded by a calm; but by the help of a brisk gale which sprung up towards evening, we managed to get out of the bay by the strat at which we entered. From Jnalaschka we took with us two male Aleutians and one female. One of the former spoke very good Russian, and both had been already on all the islands east of Unalaschka, and knew their names. At midnight a thick mist arose, which lasted till seven in the morning, when the island Atrutan, with its smoking crater, and the circumjacent islets, gradually opened to view. At ten o'clork, we discovered the conical summits of the island of Unimak, one of which, called Agagedan, is likewise volcanic, and at that time emitted a thick smoke. The extreme point of another, called Chagyan, appeared to have sunk in.

In the afternoon, our view was intercepted by a thick mist. Notwithstanding, we pursued our course towards the island of Sannach, and found the depth at midnight to be 60 fathom, and the bottom muddy; but farther on the depth decreased, and the ground became alternately stony and saidy, intermingled with muscles. About five in the morning, we descried through the mist, in a straight line-before our vessel, several masses of rock, projecting from the water, which we instantly evaded, and bent our course towards Sannach, to the left of which we perceived the island of Akatum, and a part of Unimak; lying opposite to the Isanoskish strait. At the distance of two miles from Samuach, we perceived on its north-western side a ridge of mountains, rising one above another, but, generally speaking, the shore of the whole island appeared to be rather level. Its length was about twelve miles. On the west side, reefs of rocks run for six miles into the sea, occasionally projecting, and containing, according to the account of the Aleutians, many otters. At no great distance from Sannach, lie three other small and level islands. Taking a north-eastern direction from thence, we proceeded straight to the Schumagin islands, and in our way thither passed a number of islands, of which eight on our left hand had names. The first, twelve miles north-north-east of Sannach, was Nainmak. 'To the' southeast of this lie a quantity of nameless islands, that are little more than masses of earth projecting out of the water. The second is calied Animak, or the Rein-deer island, trom the number of wild rein-deer with which it is stocked. 
It is six miles distant from the former, and in like manner surrounded by insular spots of earth. The third island, Laluskich, lies fourteen miles north-east of the Rein-decr island. 'The fourth, Agajanaksisch, is situated only three miles north of the third, the fifth north-rest of the fourth, and the sixth, Kujeddach, two miles east of the fourth. The seventh island, Kitagotach, lies three miles east-south-east; and the eighth, Unatchoch, two miles north-east of the sixth. In the strait between these two latter, there is a pointed rock, that projects to a great heyht out of the water. This is, however, less. entitled to notice than the lofty volcanic mountain on the shore of Alaksa, opposite to the island Unatchoch, the summit of which was torn off and hurled down with a tremendous crash, in an eruption in the year $1 \% 36$.

On the 2 Ist, we reached the Schumagin islands, so denomiwated by Captain Bering, after the name of one of his sailors who was buried there. They are thirteen in number, of which. Unga and Ilagia are distinguished by their size; five others are called Kagai, Saluluktussich, Nunak, Tachkinach, and Kunujutanany; the rest are nameless. They are all mountainous. and lie close to each other, in lat. $55^{\circ} \mathrm{e}^{\prime}$, and long. $199^{\circ} 27^{\prime}$.

In the afternoon, we saw several small baidars advancing from these islands towards our vessel, which they overtook. although it sailed at the rate of four Itaian miles an hour. On one of them was a Russian hunter, who, according to his own account, belonged to a merchantman, which was sene with eighty Aleutians to the Schumagin islands in pursuit of otters, and was now anchoring in the Isonozkish strait. We lay to for three hours, while Mr. Billings made out an order for the master of the above-mentioned vessel.

On the 24 th, we were almost entirely becalmed. Fow of various descriptions hovered over the sea, but particularly a sort of divers, which were to be seen in immense flocks. We shot one of them, but found its flesh more fat than savoury. This bird, which is a native of the Frozen Ocean, is about the size of a common duck, with a white body, an ash-coloured back, head, and neck, a white and round tail, a cylindrical pale-green bill, red'legs, and webbed feet. It lives on the fat of dead whales, is very bold, and often lights on the vessels. We were surrounded likewise by a number of cetaces, a species: of whale, which leaves a fat behind it on the surace of the water, that is very acceptable to the mews and divers. Sealions and sea-bears darted out of the sea, very often near our ship.

'I'owards the evening, we discovered, north-enst $40^{\circ}$, a tolerably large and steep rock, sturounded by other stony masses. 
projecting out of the water. It is said to be the abode of sea-lions.

On the 25th we touched at the seven Eudokejusch islands: the three first of which are called Abeksinoi, Samidin, and Agejeeh; and the four last, which are much smaller, have no name. They are all hills, very contiguous to each other, and surrounded with reels of rocks, both visible and invisible. While in the strait between these islands, our course was arrested by a perfect calm. We found ourselves in latitude $56^{\circ} 10^{\prime}$, and longitude $202^{\circ} 5 \mathrm{I}^{\prime}$, having 50 fathoms depth of water, and a white gravelly bottom.

In the afternoon several Americans came in their double and treble-seated baidars, on board our ship, accompanied by a Russian hunter, who, as he informed us, was sent with three islanders from Shebebow, a village in Kadjak, to catch sea-lions and fowls.

One of these Kadjakers, who attended this hunter, and appeared to be about forty years of age, differed altogether from the others, having the appearance of a female, with his nose punctured, and rings of pearl-enamel in his ears. We learnt from the hunter that this man supplied the place of a wife to one of the islanders, and performed all the offices belonging to the female sex.

The calm contiming, our ship was barely carried onward by the tide through the strait. In the mean time Mr. Billings and the doctor went on shore, and shot some marine birds, 'which are very numerous on these unimhabited islands, because they are seldom or never disturbed by the inhabitants of the other islands. In the cvening a gale sprung to the sonth-east, but we could not profit by it, because two of our hunters were not yet returned from the chase. On their arrival the next morning, they said that, from having extended their walk too far on the preceding evening, they had been obliged to sleep in the open air. We now unfurled our sails and steered for Kadjak. At noon we found ourselves in latitude $56^{\circ} 20^{\prime}$, and longitude $203^{\circ} 21^{\prime}$. Soon after we descried, at a distance of 20 niles towards the. south-east, in latitude $56^{\circ}$, the flat island of Elkamok.

On the 27th we got sight of Kadjak. 'The wind, which had been favourable for two days, changed its quarter; but notwithstanding we were enabled, by a gentle north breeze, gradually to approach the islands of Tugudock and Sitchinock, lying on the south-western point of Kadjak. During the whole night the wales swam around our ship, and perpetually occasioned, by their violent lashing of the waves, a report very similar to that from the discharge of a cannon.

On the $28 t h$, several islanders came in their double-seated baidars to our ship, without betraying any symptoms of fear. 
They offered nothing to sale; but soon after returned to their habitations. In the mean time a favourable gale sprung up, by the ait of which we made towards the south-western point of Kadjak ; the depth of water decreased to 16 fathoms, the ground was sandy, and in some places gravelly.

After passing the island of Tugudock at noon, we entered the strait between the south-western shore of Kadjak and the island Sichtunok. Close to the shore of Kadjak lie four inlets in a line, the first and largest of which was Anajachtalich, and the latter, which affords the view of a lofty mountain, is called Nasikach. We bore round to the southern side, and put into the harbour of Erech Swatitely, north-north-west, between the island Sachlidock and Kadjak, from whence the agent to the Russian merchant Schelechow's establishment came out to meet us. The strait, at its entrance, is four miles'and a half broad; its depth at first unfathomable, afterwards 75 and 70 fathoms with a muddy bottom.

On accomt of the calm that succeeded, we were obliged to hoist out the boats and tow our vessel; but a brisk gale springing up fair for the harbour, we entered it after a little veering; and tacking our ship, we moored it. The harbour of Erech Swatitely which is called by the inhabitants Manikaksak.

It lies on the left side of Kadjak, in the above-mentioned strait, at the entrance of the very secure creek of Lachik. The harbour is not large, being sheltered and formed by a neck of land jutting out of a mountain, and bending in an arch round the same mountain, by the creek of Lachik. At its muth it is 60 fathoms broad, and from five to eight deep, but the depth in the middle goes to 12 fathoms. Its bottom is muddy, and it is one verst and a half in extent.

'Towards evening we went on shore and visited Schelechow's factory, established on the southern side of the haven, along the shore. It consists of mud-walled huts, a store-house, and two jobas, built of alder-wood, which is transported in barges from the eastern side of the island. It is inhabited by Russian hunters, who are under the inspection of a Delawa Greek. In one of the huts we found several children of the inlrabitants of this island, who serve as hostages for the fidelity of their parents. They are treated very well, and not strictly contined, being permitted not only to see their parents, but even to go to their homes occasionally for a short stay. The former are, however, obliged to provide them with food and every necessary.

The island of Kadjak has been known to the Russians for thirty years. Schelechow has denominated this island Kychtak, which, in the language of the Kadjakers, designates every large island; I have, therefore, called it by the particular name which it has received from the inhabitants. In the year 1763 the translateur

SARYTSCIEW, VOL. 11.]

$$
\text { c }
$$


Glotow wintered here with the merchantman belonging to $\&$ trading company: in the year 1765, Bragin did the same with another ship, and in the year 1770, the steersman Otscheredin. In the first expedition to Kamtschatka, Captain Behring discovered this island on his return from America, and called its north-eastern cape Cape Hermogenes; Captain Cook called the same Cape Greville; and the islands Tugudock and Sitchtunock, Trinity Islands.

On the 30th we carried our water-casks on shore, and exclanged our foul and stinking water for the fresh and pure liquid that llowed in a gentle stream from the mountain. On the opposite shore we erected an astronomical tent, and close by it a common kitchen. The islanders flocked to us every day, as curious and wondering spectators, and particularly admired the extraordinary size of our yessel compared with their barges. They offered us nothing for sale, probably from a dread of the Russian hunters, who monopolize to themselves all they have to sell.

The inhabitants of the island of Kadjak, although in the neighbourhood of the other Aleutians, are notwithstanding widely difierent from the rest of their nation. They are much taller, have fat and depressed faces, and a language altogether different. Their clothing cousists of a single robe of birds' skins sower together, without any decoration, and a little flattened hat of plaited roots. They cut off all their hair, except one tuft on the crown, which they grease with fat, some likewise strewing it with a red powder, and in addition to that with the white flue of birds. One of them had pierced the gristle of his nose with a pointed bone, four inches long; and another had taken some corals to serve as a similar ornament. On particular holidays and festivals, they besmear their faces with various colours, marking them with lines and divisions of black, white, and red, according to their several tastes. Their baidars, or principal canoes, are double the size of those of the Aleutians, but much shorter, being commonly double-seated, and often only single-seated, with a short oar, like a shovel. I have not seen their liabitations, as there were none in the vicinity of our harbour; but, according to Captain Billings and the doctor's account, who, on an excursion to Sachlidok, saw several of them, they resemble those of the Aleutians. The number of inhabitants on Kadjak, and the circumjacent islands, Aphognak, Sachlidok, Schujech, Tugidok, and Sichtunok, is computed by Delarow at three thousand.

On the $3 \mathrm{~d}$ of July, I sat off very early in the morning to take the Bay of Laelick. It commences at the haven of the Three Fathers, where it is a mile in breadth, and penctrating about three miles and a half into the interior of Kadjak, in the direction of north and north-west, and afterwards bending to. 
south-west, and terminating at the distance of two miles. Its inner shore is divided into two sandy curves, which are occupied by two bronks of pure sweet water, flowing from the contiguous mountains. From its entrance to its bending, it has 55, 60, and 50 fathoms water, from thence to the interior 45, 40, and 30 fathoms on a muddy bottom. Close by the shore the depth diminishes to seven fathoms, and the bottom has a mixture of sand and gravel. The shore of the bay is every where mountainous, and occasionally steep. No wood is visible, except near the brooks, and a ferv alder-shrubs in the nooks of the mountains. I returned to the ship from this excursion very late in the evening.

On the 6th, we made every preparation for resuming our voyage, providing ourselves with every necessary, filling our casks with fresh water, and removing our kitchen and astronomical observatory from land. By observations during our stay, we found the northern latitude of this place to be $57^{\circ} 12^{\prime}$, and the longitude, according to the distance of the moon and stin, $205^{\circ} 47^{\prime}$ from Greenwich. The declination of the needle was calculated by the azimuth at $26^{\circ}$. The height of the tide was observed to be three or four feet, and its average time of commencement at a quarter before twelve.

The inspector Delarow gave us two interpreters, one of which was a Kadjaker, the other an American, from the shores of the Cape St. Elias; both spoke good Russian.

On Delarow's learning that we intended to steer for Kenaiskish Bay, he begged to accompany Captain Billings thither, for he had there an Artell of Russian hunters, from whom he had received intelligence that a Spanish three-masted vessel of war was arrived, and lay at anchor off Cape Elizabeth. An Artell signifies a company of men among the lower ranks, who are united for some common trade or occupation.

\section{CHAP. III.}

DEPARTURE FROM KADJAK FOR THE SCHUGATSKISH BAY, WITH AN ACCOUNT OF SUCCEEDING EVENTS.

O $\mathrm{N}$ the 6 th of July, we cleared out of the harbour, and got under sail, bearing away for the south-eastern cape of the island Sachlidok, beyond which a rock separated from it at the distance of a verst rises out of the sea. On the $7 \mathrm{th}$, we stood off to the north of Kadjak, and found its shores very mountainous and woody; likewise passed many creeks that penetrated into the different islands, and afforded, according to Delarow's assurance, very convenient stations for anchoring. We were 
now in a latitude of $57^{\circ} 25^{\prime}$, and a longitude of $207^{\circ} 15^{\prime}$, at a distance of fifteen miles from the north-eastern cape of Kadjak, marked on the English maps by the name of Cape Greville, thirteen miles more to the south. Commodore Behring saw it on his return from Cape St. Elias, and called it St. Hermogenes; the Russian hunters call it Jelourgi, or the fir-mountains, from its quantity of wood.

On the 8th, we came within sight of the small island of Ewrawirtschig, which is two miles distant from Aphognak. We were then in latitude $58^{\circ} 10^{\prime}$, and longitude $207^{\circ} 45^{\prime}$, the above island being $55^{\circ}$, to the north-west, about ten miles from us. Captain Cook entitled this St. Hermogenes, and fixed its position fifteen miles more southward; from whence we should conclude, that a thick mist had given rise to this error in his calculation of the latitude.

Towards evening we descried the islets lying at the mouth of the Kenaiskish bay, or in Cook's River, and at a distance Cape Elizabeth. The approaching night, and contrary winds, prevented us from going nearer, and afterwards being driven by the tide far towards the east, a thick mist continued to intercept our view.

On the 12th the fog dispersed, and we discovered at a distance of five miles northward, the mountainous shore of America. We soon after saw two Americans, rowing up to us in a single-seated baidar. Before they got up to our ship, they made a stop, and extending their arms, repeated the word Cali! cali! We invited them by our interpreter to come on board, but they appeared to be long irresolute; and when induced by our repeated assurances to venture, they complied with manifest signs of apprehension.

From these Americans, we learned, that the bay ahead of us was called Nuka, and the cape that presented itself on its eastern side, belonged to an island, which was separated from the main land only by a strait. They added, moreover, that in this bay were several of an inferior size, with sandy bottoms, which furnished good stations for shipping. Their habitations lay in one of these havens, to which they invited us with much cordiality. Captain Billings ordered the ship to tack, and put into the bay, after which we bore up to the island in question, passing a rock to the left that was about two miles distant from it. On arriving at the bay, Captain Billings found it most prudent not to advance. We accordingly tacked about again, and soon gained the open sea. In the mean time, the Americans left us.

Nuka bay is seven miles and a half broad at its entrance. It extends uine miles in length, having mountainous and woody 
shores. In the interior shore of the bay, we found in the cleft of a mountain, snow or ice, so high as almost to reach above the tops of the trees.

In the morning of the 13 th, we were perfectly becalmed. Delarow now seeing it impossible for us to run into Kenaiskish Bay, left us, and rowed with his treble-seated baidar to Cape St. Elizabeth. At noon, we found ourselves in $59^{\circ} 1 \sigma^{\prime}$ latitude, and $209^{\circ} 26^{\prime}$ longiture, Nuka bay being then nine miles distant from us north-north-west.

To the 16th, we were carried backward and forward with a gentle wind, or an entire calm, by the tide, along the shore of America; after which a southern gale sprung up, and enabled us to direct our course to Schugatskish Bay, called by the English Prince William's Strait. The wind in the mean time veered to the south-west, and afterwards to direct west.

On the 17th towards noon, we made up to the island of Tschukli, called Montague by Captain Cook, the southern point of which was then about two miles and a half from us. After passing that point, we turned to the north, and ran along the eastern side of 'Tschukli. The island is mountainous, and occasionally woody. Opposite to the middle of its eastern shore, we saw at a distance of two miles, five rocks or small islets, in a line one behind the other. Close by , these rocks, we were perfectly becalmed, in a depth of 45 fathoms water, and a bottom full of gravel and shells.

On the 18th, we bore with a south-east wind to the north, along the island of Tschukli.

On the $19 \mathrm{th}$, we found ourselves in $6^{\circ} 2^{\prime}$ latitude, and $214^{\circ} 9^{\prime}$ longitude, at which time the north-western point of 'Tschukli, was ten miles and a half distant from us to the north-west; and the projecting rocks at the entrance of Schugatskish Bay, three miles and a half to the north-east. The latter are the abode of sea-lions in abundance.

In the afternoon, we were visited here by two Americans, who, in like inamer, made a stop at some distance, and extending their arms, cried Cali! cali! Nó persuasions of our interpreters could induce them to do more than come along our ship's side. We gave them some glass beads, with which they inmediately departed, promising to return with more of their companions.

Towards evening we ran into the mouth of the bay Nutschek, lying to the right at the entrance of Schugatskish Bay, opposite to the northern point of Tschukli. We cast anchor immediately at the entrance seven fathoms deep, in a sandy bottom, at three cables' distance from the shore, opposite to a spring gushing out from the cleft of a rock, from whence we 
could conveniently fill our casks. We found the whole shore, and the contiguous mountains, overgrown with birch and aldershrubs, and a particular sort of tree resembling a fir.

Farly on the morning of the 20th, some Americans came on board our ship, and formed an acquaintance with us. The following days they came in greater numbers, offering us pieces of otters' skin, arrows, and wooden house-utensils, for which they particularly preferred taking small blue glass beads in exchange. In their traffic they often used the words amico and plenty, which they had learned from other vessels, that must of course have been Spanish and English.

The Americans of this part are of a middle size, and a brown complexion, with black, straight, and bristly hair, being upon the whole very similar to the Aleutians. Their whole dress consists of a vest of birds' skins, and their hats are of platted roots, like those of the Kadjakers. Some have their under lip cut through an inch and half deep, and parallel with the mouth, wearing, in the cavity little plates of green jasper, three quarters of an inch broad, and two inches three fourths long. Their baidars are double or single-seated like those of Kadjak. We did not see their habitations, there being none in our vicinity. Our guests also informed us, that they lived at a great distance.

On the 21 st, Captain Billings announced to us, that agreeably to her Imperial Majesty's most gracious ukase, he was promoted to a captain of the first rank, as soon as he was arrived with the ship entrusted to him at Cape St. Elias; and as he had reached that cape, according to the maps given him by the Board of Admiralty, he now assumed that rank.

On the $.2 \mathrm{~d}$, I received a written order from him, to navigate the interior of Schugatskish Bay, in order to survey the shores, and ascertain whether they belong to the continent, or an island.

One of the Americans agreeing to accompany me in his baidar, and tell me the name of the islands and brooks, $l$ treated him with great kindness, made him presents of enamel and beads, invited him to my cabin, and treated him with tea, which he liked very much, on account of its sweetness. But after he had drank his tea, he concealed the cup under his clothes, and wanted to take his leave. I demanded it back, with the assurance, that $\mathbb{I}$ could not possibly spare it; upon which he retumed it, declaring that he thought it had been given him as a present with the tea. It is in general worthy of observation, that the inhabitants of these parts have a violent propensity to theft. A day seldom passed in which something was not stolen from us, of our people. Many times they tore 
out of one's hand what struck their fancy, and instantly made their escape to the shore. As an American was once conversing very familiarly with one of our hunters, he all on a sudden snatched his cap from his head, and springing into his baidar, was making off in all haste to the shore, when he was overtaken, and obliged to restore the plunder. Another plucked the scissars out of our taylor's hand, and made his escape. Our sailors, however, treated these savage people with great civility, and conducted themselves so peaceably, that only one difference arose, which was however quickly settled. An Artell of sailors had invited an American to dine with them on buck-wheat grits, of which he took a spoonful in his mouth, and swallowed a little, but as he did not like it, he spit out the remainder into the common dish. At this the sailors were highly provoked, and in the heat of their anger, were going to deal their blows upon the poor wretch; but on hearing the noise, we hastened to the spot, and delivered him from the assailants. He him self, however, was all the time at a loss to conceive the cause of their anger, and requested an explanation; which was no sooner given him, by observing, that he had made the mess unpalatable to the rest, than he in his turn was no less offended at the indignity offered him, assuring them that his mouth was not unclean, and that none of his countrymen would have objected to eat after him.

On the $23 \mathrm{~d}$, I set off on my excursion, having an inspector of the mines with me, to collect natural curiosities, sixteen men for my crew, and one of the Kadjak interpreters. At first, we passed the bay of Nutschek, which is about two miles broad, having in its centre three lofty rocks rising out of the water.

From the bay of Nutschek, the shore winds for eleven miles towards the north, and then turns to the east. We continually kept close to the land, and found it, for the first four miles, mountainous and steep, but farther on more woody and more level. Here we were overtaken by four baidars with six Americans, who continued as our guides until evening. On our looking out for a station for the night, they advised me to go on as far as the mouth of the brook, which we found abounded greatly in fish; but as I would not follow their advice, they left us, and pursued their own course. We took up our night's abode in a little creek, and after going on shore to prepare and eat our food, we returned to our bark, hauled it of a little from land, and lying-to with a small anchor, kept a watch all night, to prevent being surprized by any unexpected attack of the savages.

The uext moming I pursued my course, and soon passed the brook, to which the Americans had, the evening before, invited 
me. On the shore stood a cross with a Latin inscription, similar to what is found on catholic crosses. After making sixteen miles, we bore away to the right, for a bay which was two miles broad. The shore on both sides was at first level, and afterwards rose into inconsiderable mountains.

Towards noon we were met by eight double-seated baidars with Americans, among whom were some of our acquaintances, whom we had already seen in our ship. They had been on the chace after others, and told me, that the waters in which we were sailing, which we had taken for a bay, was only a narrow strait that leads into the open sea, but scarcely passable with their small baidars. They mentioned to us, likewise, a small island on the left side of the shore, which was, in like manner, separated from the continesit by a narrow strait. Both we and the Americans landed on this island to prepare our dinner. They hauled their baidars on shore, and took out a young female otter which they had just killed, and two young otters, for which I gave then some enamel and beads. In the mean time, my dimner being dressed for me, our new companions flocked around it with eager curiosity. I invited them to partake of the meal, which they joyfully accepted, and discovered so much civility on the occasion, that I was occupied more with observing their movements than with eating. On the other hand, they were not deficient in hospitality, but invited me, in their turn, to partake of some boiled otter's-flesh, which they had just prepared. A keen appetite, and a rather savory smell, induced me to accept the uffer. When hot, the flesh had an agreeable flavour, very similar to that of a sucking pig; but when cold, it leaves a strong taste of sea-weeds in the mouth.

After dimner we parted from our friendly Americans, and bent our course up the strait; but a thick mist coming on, we kept close to the left shore. 'Two hours after, the mist dispersed, and left both the right shore and the sea open to our view. I now steered in an oblique direction across the bay, in order to measure it, and found its depth $2 \frac{1}{2}, 2$, and $1 \frac{1}{2}$ fathoms; its bottom sandy, and its breadth $1 \frac{1}{2}$ mile. It was then high water, but fearing lest 1 should be stranded on the return of the ebb, I tacked about in the evening, and arrived before break of day the next morning in Shakutskish Bay. I would fain have examined the whole bay, but the want of provisions, and still greater want of time (being limited by my captain to only four days longer), obliged me to relinquish a farther examination, and commence my voyage back towards Elava.

On the 25 th, we spent the last night at the distance of $6 \frac{1}{2}$ miles from Nutschek, when we met with some families of Americans close by the shore of the sca. Some of them lived in 
huts of boards fixed together; others under large leathern baidars, placed in an inverted position. As, they saw us approach, they made their usual movement of extending their arms, and crying Cali! cali! No sooner had I stepped on shore, than one of them came up to me, and laid his cheek on mine. This man was considerably taller than the rest, and had his face dyed with a black colour. The interpreter told me, that he and another standing close by him, were the Troies, or elders in their tribes. It was manifest, that they had not at first a complete confidence in us; but $I$ addressed them kindly, and assured them, that, so far from offending them, we wished to be on the most friendly terms with them. They now pointed to the sun, which was meaut to signify that they had no evil intentions: "You be as good to us," said they, "and conduct yourselves better than those who formerly came here with their ships to our shore, and why should we then quarrel with you?" I wished much to know of what nation these ships were, but they were unable to give me any information of this kind, only saying, that two and three masted ships arrived here yearly, and that in this year two had lain in Kenaiskish bay. It then occurred to me to enquire about Commodore Behring : whether they remembered any thing of a vessel which must have been the first that they had ever seen on their shores? I wished to learn the anchoring station of this navigator, but doubted very much whether 'T'schukli were the island, which he denominates the Cape of St. Elias, as this was marked in the charts delivered to us by the board of admiralty. One of the Americans then actually told us, that his father had related to him something of this ship; which, however, had not landed at Tschukli, but at the island of Kadjak, that lay about two days' sail to the east of this place, and was actually resorted to in the summer by the Americans, who went in pursuit of otters. The crew of this ship went on shore, and left them some knives and beads.

A few years after another and larger ship arrived there, which was stranded on the island of T'schukli, and not a single man of the whole crew was saved. Towards evening the Troies brought me two small boards, four feet long, two feet broad, and half an inch thick, and begged me to accept them as a token of friendship. I presented them each in return with a looking-glass, a knife, and some beads, which they very joyfully accepted, warning us to take particular care of our things, and be on our guard against some of their comtrymen, who had a strong propensity to rob us. The very next moming we experienced but too fully: the propriety of the caution; for, notwithstanding all our vigilance, an American drew a jacket from under our steersman's lad so dexterously, that though the boy was not sleeping, he had not the

SANYTSCHEW, VOL. II.] 
slightest suspicion of what iras passing. The thief changed his dress, besmeared his head and face with a red dye, and came with his companions to us again as usual; but his knavery did not remain long undetected: for no sooner was the aftair made known to the Troies, than the perpetrator was discovered, and obliged to deliver up the stolen article. He brought it himself, and giving it to the lad, advised him with a smile, to take more care of his things in future.

My sailors observing to me, that they had noticed a smoke rising at a distance, I enquired of the inhabitants the cause, and learned, that it issued from their dwellings. Upon this, 1 felt a desire of visiting what I supposed to be their winter-habitations, and requested them to conduct me thither. They willingly complied with uy request, and 1 set off in their baidar, accompanied by my interpreter. Running first up a rivulet, we crossed a lake that was about five versts in extent, not very deep, and overgrown with sea-rreed. We landed on the other side, not far from the mouth of the brook; but instead of winter habitations, we only found a few inverted baidars, and a hut made of planks set together, in which some women were living with their children. They had taken up their abode here, for the purpose of fishing: the mouth of the brook abounding with all sorts of fish, particularly one called the hump-backed salmon. This is a fish of the salmon species, about a foot and half long, having a small head, a sharp nose, and from whence a hook projects, small teeth in the jaw, a bluish back full of round blackish spots, a blue tail, singularly turned up, and white Hesh. It receives its name from a large hump which grows on the back of the inales, when they are lean. They abound in the lakes and rivers of Kamtschatka, from July to the middle of October.

This brook is so shallow, that the dorsal fins of the fish going against the stream, almost perpetually rise above the water; and we witnessed a dog seizing the fish with the greatest facility, and dragging them with his teeth to the shore.

The women had on old vests of otters' skins, and their hair was tied up in a knot on the crown of their heads; but their faces were not so disfigured as among the Aleutians. After making them some presents of enamelled articles, beads, and needles, I returned to my bark.

At noon, I took my leave of the Troies, with thanks for their civility and assurances of our friendship; after which, I departed, and reached Slawa in the evening.

During the whole of our voyage, I had great apprehensions of an attack from the Americans, and for that reason had uniformly adopted the precaution befure-mentioned, of sleeping at 
a distance from the shore, and of having one person to keep watch all night. To this precaution, which then appeared superfluous to my companions, we were most probably indebted for the preservation of cur lives. A rude people, who know of no moral feeling to check their inclinations, will follow the impulse of the moment, like the brutes, and from a trivial motive, wvill sacrifice the lives of others, when they impede the indulgence of their wishes. We were in great danger of having evinced the truth of this remark, by a melancholy example. The savages had learned from our interpreter, that $I$ had much hardware and beads with me, which awakened in them the irresistible desire of getting possession of these treasures: as it appeared, however, impossible to steal them, they took the resolution of murdering us all on a convenient opportunity. They consulted with our interpreter, pronising him his liberty, and their assistance in conducting him back to his comntry, and at the same time threatening him with the most dreadful punishment, if he should make the least discovery. Nor did he in fact tell me any thing of the plot, until some time after. 'Their conspiracy was the first time to have been executed on the first day of our leaving the vessel; for that reason they advised nie when I halted for the night, to go up farther towards the fishing brook, thinking that that would be a more convenient place for them to effect their purpose; as had already been the case with some Spaniards, who, according to their own account, relying on their sincerity, had been so imprudent as to extend their rambles without any precaution. 'The second time they took the resolution of surprising us, was when we went on the shore of the strait to take our dimner. For this purpose, a party of thein, to the number of more than twenty, continued sailing about our bark. They were in eight doubleseated baidars, two in each, sitting in their proper places, and the third lying at the bottom. The betier to conceal their design, they affected great civility, and expressed an eager desire to do us some service; while, watching the opportunity of our going on shore, they intended to carry off the bark, and thus get us completely into their power. But finding themselves frustrated in this expectation, they began to throw off the mask, and offer our sailors many open insults. I now commanded my men on the one hand to avoid every cause of quarrel, and treat them with civility, while on the other hand, I strove to inspire them with terror, by letting them see the effect of our fire-arms. I accordingly desired one of our hunters to fire among a flock of mews, as they were passing; and he fortunately hit one of them, and brought it to the ground. They were at frst frightened at the report, but afterwards eyed the dearl bird 
with wonder and curiosity, enquiring where the arrow was with which it had been struck. The interpreter, at my desire, then explained to them the nature of our guns; and in order to render it still more intelligible, I had a ball shot through a post, which excited their amazement to that degree, that they continued for some time fixed in thoughtful contemplation. In the mean time, we had all our things brought back to the bark, and, putting off from the shore, sailed away.

Both parties of Americans were composed of stout young people, who were all of an age to undertake any daring enterprize of this kind. Let it not, however, be suppose 3 from this circumstance, that all the natives are equally treacherous. The Americans with whom we spent the preceding night, conducted themselves with great openness, faimess, and civility; and although they had the most favourable opportunity of overpowering me and my companion, who were amidst them unguarded and unarmed, yet I never discovered any inclination in them to offend or injure. I also granted them my coufidence, because they were for the most part men of respectable appearance, and advanced in years.

On the $27 \mathrm{th}, I$ returned to the ship, which I found still unprepared for pursuing its voyage. They were still cutting wood, and filling the water-butts. From the wood opposite to where we lay, they had cut a stock of poles, spars, and yards, and also some trunks of American firs, which in appearance are very similar to our own, but excel even the larch in strength and solidity; being likewise of a sufficient size for tolerably large vessels.

The Americans did not provide us with fresh fish, but we managed, by means of our own nets, to lay in a stock for ourselves of the hump-backed salmon, and other smaller fish.

CHAP. IV.

DEPARTURE FROM SCHUGATSKISH BAY TO THE EAST

OF THE ISLAND OF KADJAK, AND RETURN THENCE TO KAMTSCHATKA. - ARRIVAL AND WINTERING IN THE HARBQUR OF PETROPAULOUSK.

O Towath soth of Jily we weighed anchor, and put to sea. theon we were in the middle of the strait, between the bay of Nutschek and the island Tschukli, in latitude $60^{\circ} 16^{\prime} 4 \mathrm{~S}^{\prime \prime}$, and longitude $213^{\circ} 2^{\prime}$.

Till the $3 \mathrm{~d}$ of August we stood to the east, keeping in close with the shore, which appeared to be sandy and level, but backed at a distance by some mountains. In the morning we 
saw three islands ahead of us, one of which was called Kadjak, or according to Cook, Kay. It is mountainous and woody, standing out beyond the other contiguous islands, stretching in length from north-east to south-west, and having on the latter side a particularly remarkable mountain that declines to the sea, with a steep declivity, which is so white, as to be hardly distinguishable from snow. On the southern side only it appears so steep; but on the eastern and western, almost entirely level. At some distance we perceived a lofty kekur, or pyramidal stone pillar, rising above the water; and on the shore we descried, among the ridge of mountains, one remarkably lofty, and covered with eternal snow, to which Captain Cook gave the name of Cape St. Elias. This then was the place to search for the cape, denominated by Commodore Behring, the Cape St. Elias, for the position of the island Kadjak, its kekur, its lofty mountain, or crater; and the coincidence of the latitude with that mentioned in Behring's journal, evince that the first ship which the Americans spoke of to us, as having been seen by their fathers at that island, was Behring's ship.

Our stock of sea provisions at this time ran very low, and as we had now no prospect of recruiting it any where, but in the harbour of Petropaulousk, it was unanimousiy resolved to bend our course back to Kantschatka, which was a voyage of not less than two months. Here we expected to find the necessary supplies provided for us, from Ochotsk, during the summer. Had it, however, been contrived for the provisions to bave been sent us to the island of Kadjak, or Schugatskish Bay, our return to Kamtschatka for the winter, would have been rendered superfluous, and our time might have been usefully employed, in surveying the southern shores of America, and réturning in March again to the north.

Captain Billings resolved on an immediate and direct return to Kamtschatka, without stopping any where, which was in fact rendered necessary by a want of water and biscuit; on which account our people were kept to half allowance. Thinking ourselves however, on the $29 t h$, in the neighbourhood of Unas laschka, Captain Billings consulted with the officers, whether we should fouch at that place to take in fiesh water; upon which it was agreed, that, from the lateness of the season, it was most alvisable not to lose any time in hastening to Petropaulousk. We were indeed bound by our promise to restore the Aleutians, whom we had taken with us as interpreters from Unalaschia, to their homes; and, Hattered with this expectation, they were perfectly contented, until they found we were beut. ing our comse direct to Kamtschatka, when their satisfaction was changed into the most poiguant distress. In a lit of de- 
sperate aftiction, one of them cut his throat; but the wound, which was not mortal, was quickly healed by our surgeon: however, the man died soon after our arrival at Kamtschatka.

On the 30 th, we discovered, in gloomy weather, to the northwest half-west, some land with two moutains, which was, however, soon intercepted from our view by the mist. The two following days we changed our longitude $1 \frac{1}{2}$ degree westerly, but continued in the same latitude, and saw on the 1st of sepcember, the same land afresh to north-east $63^{\circ}$. Many more sea-birds than usual now made their appearance, and among them Urilas, which according to the general observation of navigators, are a sign of land being near. At this time we observed the latitude to be $53^{\circ}$, and calculated the longitude at $190^{\circ} 2^{\prime}$; but afterwards, having an opportunity of rectifying our observations, by the distance of the moon from the sun, we discovered that we were then seven degrees more to the east. According to this latitude and longitude, we concluded that this land could be none of the islands known to us, and of course must be some new island.

In my opinion, there are, both north and south of the known cluster of Alcutian islands, others hitherto undiscovered, which appears corroborated by the otters, lions, and other marine animals, passing the Alentian islands, in the month of July, from the south to the north; and afterwards returning in October, from north to south: whence we may conclude, that they spend the summer in this cluster to the north, and the winter in the one yet unknown to the south. The northern cannot, however, be situated farther than the 6oth degree, nor the southern beyond the $45 \mathrm{th}$, for between these degrees only are otters and sea-lions to be found.

On the 4th of September, in the afternoon, a violent squall split our top and foremast and bowsprit, which we repaired on the following day. Since our departure from America, we had continual contrary winds, and being almost always obliged to deep to vindward, we had not been able to make more than half our way in fifty-two days. Petropaulousk being still at a considerable distance, we found greater economy necessary, having only twenty tuns of water remaining. All in the ships, both officers and men, now received only a pint a day; and in order not to provoke our thirst, we abstained from salt-meat, and lived entirely on boiled peas.

On the 24th, we discovered in the morning to north halfwest, the lofty snow-covered mountains of the island of Tanaga, and towards the north, the lofty crater of the island of Gorelin, fifty miles distant from us. The next day we got sight of the small and almost level island Anatyguak, which vas at 19 
miles distance. We found our latitude then to be $50^{\circ} 48^{\prime}$; our longitude $169^{\circ} .86^{\prime}$; and the inclination of the needle $11^{\circ} 19^{\prime}$ easterly.

On the 5th of October we were enabled to rectify on whervations by the distance of the moon from the suin, and fixed our longitude at $167^{\circ} \mathrm{i} 0^{\prime}$; whence we perceived that we had calculated $11^{\circ} 16^{\prime}$ too far forwards. The error arose since our departure from Schugatskish Bay, as the tide of the sea was unknown to us, and we had much contrary wind, being mostly west, but sometimes inclining to the south, or south-east.We had a complete east wind only once from the second of October, for forty-eight hours in succession, and never north or north-east wind. At the same time we made the observation that with north-west west; and south-west wind, the atmosphere was not thick but overcast, and that south-east, south, and east winds, on the contrary, always brought rain and mist.

On the 6th of October we had only eight ten and a half of water, and a voyage of 350 miles to the harbour of Petropaulousk; on which account our allowance was again diminished to eight small glasses a man daily, for cooking and drinking. Some bore this deprivation with perfect patience, but many were dreadfully tormented with thirst. They often took blood into their mouths in order to alleviate their sufferings. Nothing could equal the joy which the appearance of rain occasioned, nor the eagerness with which every one strove to catch it. Every change of weather, however trivial, was watched with the utmost inquietude; if it was favourable, the hopes of all were flattered with speedily reaching the harbour, and the hours were calculated which the ship would require, at the given rate, to complete the voyage; but a contrary breeze would as quickly disperse all our hopes and calculations, and cloud every comtenance with the sadness of despair. At length, after four days veering and tossing about, we approached the shores of Kantschatka, and, with indescribable delight, we perceived, on the 10th, the Shipunish promontory, and the lofty crater of Wilnishninish. We were not able to get into the Awatscha bay before the 13th, and not into the harbour till after midnight, when we laid our vessel to, in the very spot where it had lain the preceding year.

Our joy at having thus happily terminated our peculiar voyage, may be better conceived than described. Our water was al ready reduced to the lowest ebb, and had contrary winds detained us but another twenty-four hours, our situation would have been lamentable in the extreme. It is rather surprising, that with all our deprivations we remaned healthy, and experienced no ill consequences whatever. We swallowed the farst 
fresh water which came within our reach with the utmost avidity, and certainly found it the sweetest beverage we had ever enjoyed in our lives. In a couple of days our whole crew was removed on shore, and quartered in the old jurts we had built for ourselves. We unrigged the ship, and brought all our stores into the magaziue. We found the galliot already there, which had been sent from Ochotsk with provisions for us, and had also brought that part of the Dobroe Namereni's crew, which had been left behind.

To the close of October the weather remained fine, but was succeeded by rain and cold. In order to guard the stores collected at the fortress of Bolscherezsk, and to make room for us in our narrow dwellings, thirty-four men were sent thither for the winter.

In the preceding winter, Captain Billings had had the plan of building a new cutter to accompany the Slawa Rossii in the river Kamtschatka; and for that purpose had dispatched a carpenter and several other labourers to the town of Nishue Kamtschatsk. The command of this vessel devolving on Captain Hall by right of seniority, he set off on the 16 th of December, in order to inspect its construction. The necessary materials and $t$ ackling were sent after him on sledges, drawn by dogs.

We accompanied Captain Hall, and truly envied him his occupation, while we were obliged to drag through four winter months in total idleness. In order, however, to get rid of our time, Mr. Billings, Mr. Behring, and I, travelled, at the close of December, to Bolscherezsk, where the latter and I staid only fourteen days; but Captain Billings still longer. On our return, we were overtaken by a severe frost among the mountains which run through the middle of Kamtschatka, though at the same time it had thawed and rained in Petropaulousk, not a lundred versts distance.

Soon after this, Captain Behring went, with a part of the crew destincd for maming the new cutter, to Nishne Kamtschatsk.

In the latter half of January, and the whole of February, the frost was so violent that the part of Awatscha Bay, from the interior of the harbour to the muscle bay Rakowoi, was rovered with thick ice that admitted of being passed in dogsledges with great security.

At the begiming of April we began to careen our vessel, in order to examine the under part, and clear it of the sea-weeds; for, on the whole bottom, seawort was grown out five feet long, and several sorts of muscles had stuck among it to the boards.

We wercemployed the whole of April in preparing for our 
voyage. On the first of May, I went in a wooden baidar to the Shipunish promontory, in order to examine the contiguous bay, of which the inhabitantshad said much that was useful to me. We sailed immediately from the Awatscha bay with a fair wind, north-east-half-east, directly to the steep rocky mountains of Nalatschew. To this point the shore is formed by an inconsiderable curve, and begins from Awatscha bay, with a rocky declivity, but soon after becomes sandy and level as far as the mountains. Six miles from the mountains the brook Nalatschewa discharges itself, and from thence the shore becomes again sandy and level. We lay to for the night by an island opposite to the mouth of the little brook Ostrownaga, about a mile-from the nearest shore, and about five miles distant from the cape Nalatschew, which lies to the south-west, one-third west of it. Its shore is steep, and it is itself mountainous, being about a mile in extent.

On the $2 d$ of May we proceeded strait to the Bitchewish bay, a distance of six miles, which we rowed, with a perfect calm, in two hours.

The shore extends itself from its mouth, on both sides, under lofty mountains, to the Shipunish cape towards east-south-east; to the mountain Nalatschew towards the south-west; and to the bay Wachilskaja, in which merchants, galliots used formerly to winter, where we found at its mouth a bark still existing. At its entrance the bay is a mile broad, and its interior lofty mountainous shore stretches two miles north-east-by-north. Farther on there is an inner bay, or lake, four miles in extent, into which one passes by a small strait, fifty fathoms broad, and three or four fathoms deep. More towards the middle of the lake the depth increases to fifteen fathoms, and the bottom is muddy. But in the first bay the depth, at the entrance into the lake, amounts to no more than four feet; of course only small craft, and not even these but at high water, can run into this haven, which would otherwise be very excellent. We staid the night here, and the next morning proceeded on our way back to Awatscha bay. At noon we. were off the mountain $\mathrm{Na}$ latschew, where we estimated the latitude at $53^{\circ} 4^{\prime}$.

On the 5 th we returned to our ship, which was entirely equipped and victualled; but the ice still occupying the haven we were prevented getting into the roads. 
CHAP. V.

UEPARTURE FROM AWATSCHA BAY TO BEHRING'S ISLAND, AND FROM THENCE TO THE NORTH SIDE OF THE ALEUTIAN ISLANDS AS FAR AS THE ISLAND TANAGA.-OCGURRENCES DURING OUR ANCHORAGE.VOYAGE BY THE ANDREGENOW ISLANDS TO UNALASHKA, AND ARRIVAL IN THE CAPTAIN'S HAVEN.

O.

$\mathrm{N}$ the 16 th of May, 1791, we weighed anchor, and were on the point of leaving Awatsclsa bay; but had scarcely reached the light-house, when a contrary wind arose and obliged us to return and lie at anchor till the $19 \mathrm{hth}$, when, with a fair wind, west-south-west, we got into sea. Supposing that the cutter which was building at Kantschatka must be ready, we took a straight direction up the river for the purpose of meeting with it. At the same time, having given Captain Hall intelligence of our intended route, we concerted, that if he put to sea before our arrival, he was to wait for us at the northern point of Behring's Island till the 29 th of May.

On the 24th, in the morning, we descried the Kronozkish promontory, and a lofty crater, situated to the west of it. Our Jatitude was, at noon, $54^{\circ} 13^{\prime}$; our longitude $162^{\circ} 20^{\prime}$; the Kronozkish crater being $63^{\circ} 30^{\prime}$, to the north-rrest, fifty nules distant from us.

Contrary winds not permitting us to approach the mouth of the river Kamtschatka, we stood out for Behring's Island, as the destined rendezvous for our vessels.

We came in sight of this island on the 27 th, in the afternoon, and approaching its south-western side towards evening, the shore of which consists of lofty mountains, we stood in to the north-west, having always a west-south-west wind, which blew so fresh towards night that we could scarcely double a lofty rock that was separated from land. At midnight the island appeared sufficiently near for us to reach it with a stone's throw.

Ou the morning of the $28 \mathrm{th}$, we sailed round the northern level shore of the island, and then from its north-eastern to the south-eastern side. At noon we estimated the latitude at $55^{\circ} 14^{\prime}$, and the loingitude at $166^{\circ} 22^{\prime}$; being about three miles 
and a half distant from the island. Here we were very near the spot where Commodore Behring, being oblged to land, on his return from America, in order to seek assistance in his distress, terminated his earthly career. We lamented very much that it was not possible for us to get nearer lan'd, in order to visit the place where the first navigator of these seas is consigned to the peaceful grave. We would fain have heaved a sigh of regard and sorrow over his remains, and those of our unfortunate countrymen who lie buried by his side. We passed the place of meeting, and perceiving no vessel, Captain Billings resolved on steering for the Aleutian islands.

Towards evening, we were enveloped in a thick fog. Captain Billings directed our course by an English map, taken during Cook's voyage, far more northerly than the Copper Islands are there griven. As this direction, according to the Russian map, would have led us strait to the middle of the Copper Islands, I made my representations to Captain Billings, who paid so little regard to the Russian map, that I persuaded him, with difficulty, to alter his course two rumbs more northerly, and by that means alone we escaped the impending danger; for the next morning the mist clearing away, we saw we had passed the northern point of the Copper Island by no more than two hundred fathoms; nay, that from the stern of our ship we could distinguish the rocks concealed under water.

All were now satisfied that this island is marked on the English map much more southerly than it ought to be.

As I am informed, solid copper is to be found in the clifts of the rocky shore, at the fall of the water, on the Copper Island, we sailed round it, and directed our course to the first inhabited and large Aleutian island, Atta.

On the 4 th of Jine we discovered through the fog a part of the mountains on the southern side of the island Atta, which were entirely covered with snow. We were, at noon, fiften miles south of them, and got a glimpse of the ssland Agatta through the mist. Their shores appear to consist of gradually sloping mountains, being thirty-four miles in extent.

At break of day, on the 5 th, the summits of the mountains on the island Semitsch opened to view; and in the afternoon we passed the island Buldyr, lying in latitude $52^{\circ} 40^{\prime}$, and longitude $176^{\circ} 13^{\prime}$ of Greenwich ; having an extent of twelve miles, consisting entirely of mountains, and encompassed with a rocky shore. About a mile and a half to the south-west we found some rocks projecting out of the water.

On the 6th we stood off the Rat Islands, the first of which, towards the west, is called Kyska, a mountainous island; the E 2 
east side of which appears more level than the west, having a fat shore.

Opposite to the north-western side, at a distance of three miles, a lofty rocky pillar elevates itself. We could not discern the southern side of the island on account of the mist. Farther on, towards the east, four inconsiderable mountainous islands presented themselves to view, but were, towards evening, lost out of sight, as we were carried away from them by a southeast wind, and encompassed by a thick mist.

On the 9th, one of the crew descried land, and pointed out to us, almost over our heads, through the mist, the declivity of Tanuga. We sounded for the depth, but found no bottom; as the mist soon after dispersed, we were presented with the spectacle of a lofty volcanic mountain, that exposed to our view, at the distance of scarcely two miles, its black and tremendously tall side of rock. We then calculated the latitude at $52^{\circ} 6^{\prime}$, and the longitude at $180^{\circ} 22^{\prime}$. In the afternoon the wind almost entirely abated. With the tide, and ouly a gentle wind, we run along the sonth-eastern side of Tanaga.

Its shore was, in the commencement, mountainous, but rose by a gentle elevation as we proceeded. The master of the baidars, whom we brought with us from Ochotsk, told us, as he had been on this island, that at no great distance from hence there was a large commodious bay, which was used as an anchoring station by the Russian hunters. I immediately set off in a baidar to examine it, and after making about four miles from the ship, found the way lay round an isthmus into the bay, the depth of which, at the middle of its entrance, was forty fath $\mathrm{ms}$, and farther on 25 ; towards the left bank it gradually diminished, and half a mile from thence it sunk to seven or eight fathoms; at the bottom I discovered a black sand. On the other side the bay is an Aleutian residence, which we were prevented visiting by the approach of night, being anxious, if possible, to return to the vessel before the darkness came on. On our way back I found, on a jut of land, an Aleutian summer jurt, in which was an old woman, who informed me, that almost all the islanders, with the exception of very few, were gone to the island Atcha, to a Russian huter's ship lying there. We had scarcely got two miles from the bay, when a heavy fog involved us in darkness; and not finding our vessel where we had left it, we saw ourselves obligea, after a long and fruitless search, to lie to by the shore. On the following day the atmosphere was clear, but we did not get sight of our vessl, and were totally unprovided with food. In this dilemma we must soon have gone in search of the Aleutian residence, if we had not, at noon, fortunately discovered the wished-for object sailing bew 
hind a cape. We instantly made up to it, and learnt that the tide changing the night before had driven them to the north-east, where they had been laveering the whole night, and had not till then been able to regain their old station.

When Captain Billings was informed that the bay afforded a good anchorage, he immediately ordered us to bend-our course thither. With a gentle wind, and the aid of towing, we gained the bay in the evening, which penetrates, on the western side, into the island, being about eight miles long, and five milesbroad. Its shore is ocrasionally sandy, and most consists of a rocky, but not very tall declivity. We cast anchor opposite to two rivulets rumning from the inountains, in a black sandy bottom, and eight fathoms water, about half-a-mile distant from a sandy shore, under shelter of a steep promontory and lofty rocks, elevating themselves above the stream. Not far to the north of this promontory, a current of pure water eddies forth from a rock in the mountains. We could approach this stream so near as to fill our butts by the help of pails. At a distance from our anchoring-place the land elevated itself, and termimated towards the north in tall snowy mountains, from whence fire sometimes issues, but which now only emitted smoke. It appeared to be not very distant, and some of our people made the trial of going up to it, but were compelled, from the tediousness of the road, to return, bringing back only some sulphur and lava with them. The island is totally without wood, but the declivity of the mountains, and the more level parts, are covered with a tolerably long grass.

On the second day after our arrival, two Aleutians came with fresh fish to us from their habitations, on the south side of the bay; and on the 12th, we had a visit from six Aleutians in like manner, bringing fresh fish from the south-west side of the island.

On the 15th we weighed anchor, and went to the north-side of the island Tanaga. On the 16 th, we found our latitude $52^{\circ} 18^{\prime}$, and longitude $180^{\circ} 56^{\prime}$. In the evening, at the setting of the sum, we observed the declination of the needle, to be at $16^{\circ} 25^{\prime}$ easterly.

On the 17 th, we found ourselves at noon, in the strait which separates the islands Tanaga and Kanaga. This latter island has on its north side a crater of an extraordinary height, but is otherwise altogether level. Before the strait an inconsiderable island elevates itself in one lofty eminence, called the Beaver Island, at a distance of 12 miles from us, in latitude $52^{\circ} 8^{\prime}$, and longitude $181^{\circ} 37^{\prime}$. Being prevented by the ruling north-east wind, from sailing round the islands Kanaga and Adach, we returned to the strait, and stood along the island 
Tanaga, to the south. West of Tanaga, lies at a distance of 17 miles the island Gorelvi, being 17 miles in extent, and distinguished for its lofty volcanic mountain, which is covered with an eternal snow. Towards evening we passed the southside of the Aleutian Islands, of which the first two are small and flat, but the third, called lllak is higher, and lies more to the south of Tanaga. Contrary winds, first from north-east, and afterwards from enst, obliged us to laveer in sight of the islands Tanaga and Kanaga. The southern sides of both islands have a flat shore.

After being tossed about in a thick mist for two days, we descried on the $21 \mathrm{st}$, to the left of us, a cluster of islets contignous to each other, and extending to the island of Atcha; and in the afternoon we found ourselves in a strait, betwixt Atcha and an islet.

Through this strait, which is 48 fathoms deep, and has a gravelly bottom, we bore away to the north-east for the cluster of these islets, the shores of which are mountainous and woody, always rising more and more to the north, and terminating in a lofty crater covered with snow. We observed by this island many bays, the largest of which is called the Korowinsh haven, and very near the northern promontory of Atcha. 'This one also divides itself at the very entrance into two, and penetrates thus far into the interior of the island.

As soon as we were passed Atcha, we stood off with the sout:-east wind, straight for the island Umnak, and after passing its north-eastern side, we came in sight of the western part of Unalaschka. In the middle of the strait between these two islands, a lofty rock rises out of the water. We estimated our latitude at $53^{\circ} 27^{\prime}$, and longitude at $191^{\circ} 28^{\prime}$.

At ten o'clock in the evening, we approached the northwestern cape of Unalasckta, which is called Makushim, after a bay, and an Aleutian place of the same name.

On the morning of the 25 th, we came to the western bank of the Captain's Haven, where, close ahead of our ship, a number of whales of different species rose out of the water. Towards noon, we reached the eastern bank, where we anchored by the Aleutian residence Illuluk, in eight fathoms water.

This summer we had calculated our way so well, that from Petropaulousk hither, not a single error had crept into our estimate, so as to carry us out of our course.

As soon as our arrival was made known among the different villages, the natives came with fresh fish to our ship. 'Tobacco was an article of the greatest necessity among them, for which they fiocked to us from the remotest parts, not only of this, but of other islands, Captain Billings strove to oblige them, by 
making them presents of tobaccn and other trifles, and promised them still more, if they would dry a considerable quantity of tish and berries against our return. We knew their extreme attachment to tobacco too well, not to be fully assured that they would comply with our wishes in this respect.

The woman who had accompanied us in the preceding year, was highly delighted with seeing her family, and returning to her home. The liberality of Captain Billings had supplied her with many ornaments for her person, and had sn richly stocked her with tobacco and pearl-enamel, that she became an object of universal envy among her female country-women, and was esteemed the richest of all the inhabitants.

We lay at anchor for two weeks, in expectation of Captain Hall and the new cutter; but he not coming, we did not wish to lose time, and leaving him the necessary provisions and utensils, together with the surgeon Allegretti, and a hunter, in lllulik, we resumed our voyage to Behring's strait.

CHAP. VI.

DEPARURE FROM UNALASCHKA TOWARDS THE NORTH, PAST THE ISLANDS ST. GEORGE, ST. PAUI, ST. MATTHEW, FOR THE ISLAND OF ST. LAURENCE.-ARRIVAI。 THERE.- DANGEROUS SITUATION OF THE SLAWA ROSSI1.-OCCURRENCES DURING THE ANCHORAGR.DEPARTURE FOR THE SHORES OF NORTH AMERICA, AND INTERVIEW WITH THE INHABITANTS.-ANCHORAGE IN ST. LAURENCE BAY.

$\mathrm{ON}_{\mathrm{N}}$

$\mathrm{N}$ the 8 th of July we weighed anchor, and went into the sea. Captain Billings desiring to see the two islands lately discovered by the steersman Pribylow: we bore away for them in a strait direction.

On the 9 th, we were seventy miles to the north of Unalaschka, had 88 fathoms of water on a muddy bottom, and saw many sea-lions and sea-bears. This animal, called phoa ursina, is seven feet long, and of the seal species. The hair of the male is a black grey, that of the female grey, with dark spots between the fore-webbed feet. The males have a very soft hair on the breast, with a thick and tough skin: the structure of the bones is also firmer, larger, and stouter than that of the female: its head is large and round, the foreh aad extending over the eyes, and the snout having some long white bristles on it; the flaps of its ears are rather small, and externally overgrown with hair, but internally smooth, and standing out straight and pointed. The orifice of the ear is oval, and so constructed, 
that it can be closed when it is under water. In other respects, both as to the form of its body and feet, it resembles the seadog. It frequents the northern parts of the Pacific Ocean, and the Southern Ocean. The males are very jealous of the females, which they keep to the number of eight or ten, forming with them and their young, a distinct herd. Their jealousy often occasions violent and bloody disputes. The Kamtschadales kill them with their darts for the sake of the fat and the skin, which in the young ones, is little inferior to the Kamtschadale otter, for the delicacy and firmness of the hair and down.

On the 12th, we conclided from our calculation, that we must necessarily be in the vicinity of the above-mentioned islands, but an impenetrable mist prevented us from seeing them. A still greater number of sea-bears were in sight to-day, than what we had seen the day before, and a number of aars, kept hovering round our vessel.

The mist soon after dispersing, we discovered the two islands, the first of which, St. Paul's was eight miles alsead of us to north-west $25^{\circ}$, the second, St. George s, twenty miles behind us to south-east $57^{\mathrm{c}}$. The shores of these islands consist of mountains of a moderate height: on the north-eastem side of St. Paul's, sinking down to a level opposite to its south-western side, is an islet, not very lofty, but very steep in ascent. At a distance of six miles from the western promontory of St. Paul's, we found ourselves in 35 fathoms water, on a bottom of stone and shells, our latitude being $56^{\circ} 29^{\prime}$, and longitude $189^{\circ} 45^{\prime}$.

These islands were discovered in the year 1786, by Pribylow, steersman to a merchant's ship, who finding a number of marine animals and walrus' teeth, staid with his companions for some time there, and in the space of two years caught 2320 otters, 30,000 sea-bears, 480 young otters and bears, and 8000 blue foxes, besides 700 puds of walrus' teeth, which they found on the shores, all which, when calculater at a moderate rate, produced at Ochotsk 250,000 rubles. It is necessary to observe, that the otters first spoken of, are the mustelu lutris, a species of river animals about three feet long, with three feet united by a firm hairy web. Its head is flat, its snout thick, hair black, and extremely thick, at the same time as soft as down, particulariy that on the belly, which is extremely tender and of a greyish colour. The tail is a fourth part of the length of the body. It

* The aar, or ara torda alca, is the name of a liamtschadale fowl, of the species of the Gagara (colymbus areticass) or water-hen, is found in great abundance in the country of the rocky islands. Its back, head, and neck are black, its belly white, bill long, straight, and pointed, fect darkgrey, with three toes united by a web. At Kola it is called Gegarkit, 
rans, dives, and swims with great agility, is found near Kants. chacka, and on the islands of the Eastem Ocean. It lives on fish and little mane anmals. The shin of the Kamtschatkau otter is very dear, and in great request, on account or its firmness and good quality.

From these islands, we directed our course to the Island of St. Matthew, which is called by the Linglish Gore's Lsland. 'The depth which had at first increased to 55 fathoms, afterwards again decreased.

Wi the moning of the 14th, we discovered throngh the mist, a small is and to the north-east $50^{\prime}$, at a d stance of 11 miles, the suface of which appeared to consist of a chain of pointed rocks hanging over each other; it has received the nme of Pinnacle from the English. The depti was then 50 fathoms, and the bottom gravelly. As the air cleared up, we discovered the Island of St. Mather, and as we approached it, the depth decreased to 14 fathoms. We put in near its western shore. At noon we found our latitude to be $60^{\circ} 29^{\prime}$, and longitude $187^{\circ} 15^{\prime}$; the little island Pinnacle lying then to the southeast, about ten miles and a half distant, and the westem shore of the Island of St. Matthew six miles distant to the north-east.

We had scarcely passed the north-westerin point of this island, when another presented itself to view, lying three miles from the north-rest of this point. In the middle of this strait the depth was 12 fathoms, and the bottom consisted of gravel and shells. As Captain Billings wished to take a nearer view of the little island, we anchored one mile and three quarters off, in 13 fathoms and a sandy bottom. In the afternoon, $\mathrm{Mr}$. Billings, Mr. Merk, and myself, went on shore; and on our approaching the island, we were encompassed by a great number of sea-birds, constantly hovering around us, and causing so great a noise, that we could scarcely distinguish a word that was spoken. We parted when we got on land, some going into the interior of the island, others climbing the rocky sides of the shore, and oflers remaining below on the brink of the creck. A universal firing now commenced on all sides, which did great execution among the marine birds, particulinly the aars, of which a great number were carried to our ships. Our bunters also killed two black foxes, and found two walsus' tecth; and one of our company was so terrified by the sight of a large white beast supposed to be a bear, that breatiless and ahost fainting, he hastened back to the ship. On the momtans vie found large fragments of a species of Hintstone, the delicate and many-coloured veins of which were an object of extraordinary beauty. On the east side of the island there was a quantity of floating wood, near the shore;

SARYTSCHLW, VOL. Ir.] 
but the rest side, on the contrary, was entirely clear; which led us to the conclusion that on the shore of Anerica opposite to the former, a large river, after ruming through a woody tract of conbry, disemborzed itself into the sea.

Towards evening we weighed anchor, and stool out to the north, when a thick mist completely velied both the istinds from our view. The depth was 40 fithoms, but decreased as we proceeded northerly: we fom the botrom muddy.

On the 16 th, we had only 27 fathoms water, and a sandy. bottom. According to our calculation, we were then in the vicinity of St. Laurence's Islaud, called by the English Clark's Island. We lay at anchor the whole night.

On the 17 th we weighed anchor, notwithstanding the whole sea was covered with a thick mist; and after beating about in various depths of water, we found ourselves, at three in the afternoon, in only six fathoms water with a sandy bottom. We cast anchor with a quarter of the cable, but it did not bite; we then threw out a second, but with no better success. From the depth, which was then only $4 \frac{1}{2}$ fathoms at our poup, we concluded that we conld not be far from land, and although enveloped in a thick fog, we were but too well apprized of our danger from the impetuosity of the beating waves, which increased every hour as the wind blew stronger, and the surge grew more violent.

In the mean time, we gave our anchors an equal length of cable, and remained all night in safety; bat the next morning a large wave struck with immense force against the beak of our ship, and tore a cable in pieces. We then cast two anchors more, but could place litte or no reliance on the cables, which were made of had materials, and alinost rotted away from the continual damp weather.

On the 20th, the wind was somewhat abated, and the mist began to disperse, upon which we discovered abaft of us, at the distance of a mile, a level shore; our latitude being now $69^{\circ} 24^{\prime}$. In the afternoon we saw two islanders on shore, who lifted a vest up on a pole, and seemed to sway it backward and forward by way of invitation. We sent bakow the boatswain to then in a baidar with presents; but without waing his approach, they immediately went away. Being prevented by the surf from landing, he was obliged to retum.

We foumd the declination of the needle to-day, according to the azimuth, to be $24^{\circ} 11^{\prime}$ easterly.

On the 2lst, the wind dropped entirely, and the atmosphere became perfectly clear, which afforded us an opportumity of descrying, drectly opposite to our vessel, a remote shore; stretcing far to the east, beyond which we perceived from the 
tops of the mast, a large lake, and still farther on declivitous mountains occasionally covered with snow. W'owards the west the shore declined in a curve, its extreme point being 14 miles distunt towards sonth-west $60^{\circ}$. 'To the south of this point, ye saw in imagination two other islets, which proved afterwards to be nothing but thick mist.

Captain Billings, Doctor Merk, Boatswain Bakow, and the Second Licutenant Bakulin, went in two boats on shore. 'They reached the shore with considerable difficulty, the sur being very high, and overwlelming them with water. Captain Billings proceedied with some of them to the west, in search of a human residence. In the mean time, we descried from the top of the mast a baidur of islanders rowing towards us from an oprosite side of the lake. 'Ihe sailors who had been left behind on the shore perceiving them also, strove to call Captain Billings back by loud bawling; and afterwards, when they found this ineffectual, endeavoured to attract his attention by firing their guns, which, instead of producing the desired effect, unfortunately onlyz served to terrify the savage inhabitants; who, on hearing the report of the guns, immediately made off. Thus were we prevented by act of imprudence, from forming an acquaintance with these islanders. Captain Billings retumed towards evening withont having succeeded in finding the object of his search.

On the 22d, we went to the eastern point of the island, kecping close to the shore, where the depth diminished from 16 to 10 fathoms, on a gravelly bottom, occasionally mixed with sand. The shore was perfectly level, but we observed, at a distance, some mountains parted off from each other. To the east-northeast some mountainous lands appeared a-head of us, which, on a nearer approach, we found to be comected together by one level shore, and, in reality, to be one single island, which has in two places on the fiat shore some considerable villiges. On the map of Lieutenant Sinde we find, instead of this one great island, a number of smaller ones marked, which is doubtless a inilar error to what we made from a distant observation.

In the aftemoon, we stood round the south-eastem side, and went to the north-eastern cape of the island, the shore of which somewhat curves inward; six miles and a half from the sonth eastern cape we found a village close by the water." Towards evening we passed the north-east cape of St. Laurence, from which we observed, at the distance of four miles and a half, three islets, close to each other. On one of them was a pyramidal kekun, round which plank huts and poles for drying fish were erected, but we saw ho humm bengs; from which wo I. 2 
supposed that the inhabitants of the other islands came here, from time to time, for the purpose of fishing.

In the night of the $2+$ th the wind reered round to the north, and blew so strong and contrary a gale that we were obliged to haul in ail sail; but being only twenty miles off St. Laurence, we bore away to the east, and getting round the island lay to for the might.

On the 260 we found ourselves in lat. $63 \times 10^{\prime}$; and longitude $195^{\circ} 25^{\prime}$, thirty-three miles distant from the north-eact shore of St. Lamence; consequently in the spot where Anderson's Island is marked on Captain Cook's map, but we discovered nothing, although the horizon was suficiently clear.

On the morning of the 28th we saw the cape on the shore of America, called by the English Cape Rodney. At noon we calculated our latitude at $64 \times \mathrm{II}^{\prime}$, and the longitude at $193^{\circ} 58^{\prime}$. Cape Rodney was then twenty-seven miles distant from us to the north west $56^{\circ}$; Fledge isiand twentysix miles to the north-west 63०. In the evening we anchored eight miles from the American shore, in 14 fathoms water and a muddy botion.

Mr. Bllings, Mr. Merk, Bontswain Bakow, and Mr. Wo: ronin, the draughtsman, went in two boats on shore, and towards evening one of them was sent back with the intelligence, that they had found inhabitants, and having met with a kind reception from them, they should pass the night on land.

On the 29th we saw behind the cape a large baidar full of Americans coming towards us. They stopped at no great distance from us, so that we could distinguish, them without a glass. The baidar was occupied by nine men, having at its stem an extended bladder hung on a pole, and at the poop two red foxes on anotier pole, which we, of course, regarded as friendly signals. They continued, however, some time in their position without offering to approach, and with their hands raised aloft. I commanded the sailors who were on the deck to do the same, as a token that we were unprovided with any offensive weapons.

At length taking courage they came on board; but as they did not understand our interpreters we could have, but little conversation with then. They lad some red foxes, some vests of young reindeer and Alpine hares, wooden bowls, and different trilles, made of walrus' teeth, which they exchanged with our sailors for coral, pearl-enamel, and buttons, but no tobacco.

The Alpine hare, Alpinus, is of the size of a marmot, with a longish head, a snout like that of a hare, large ears, rounded in the form of a fumel, a thick body, short legs, the fore- 
feet having five toes, with a stout short toe, the hind feet fons. The soles of its feet are overgrown with thick black hair, and, in the place of a tail, it has a fat exerescence of the size of a nut. Its hair is yellow, tipped with a dark colour, and its voice whisting. It has two teats near its hind legs, and four under the breast. It is found in the Siberian Alps, where, in the month of August, it nibbles off the grass, dries and conceals it in the clefts of the mountains.

As soon as this trantic was at an end, they were on the point of departing; but our people commencing a Russian song, they turned back, came again on board, and listened with great attention. They then sang themselves, in their way, to which two of them danced. This dance consisted of many vehement gesticulations of the whole body, particularly of the hands and head, which they twisted round on all sides with great dexterity, at the same time springing from plare to place, in conformity with the singing and beating of the drum.

These Americans are of a middle stature, and generally of a brown complexion, although we saw some white among them. They cut their hair after the mamer of the Jakuts, whom they greaty resembie, except that they approach nearer to the Europeans. They have a more open cheerful physiognomy than the Americans we saw in Schugatschkish Bay. In their ears they wore an ornament of pearl enamel, and in the perfom rations of the under lip, on both sdes the mouth, they strick two alabaster stones in the form of a shirt-button. Their dress consisted of short vests of reindeer skin, and breeches of seahound's skin, without any covering for the feet. I made these visitors some trifling presents, which they accepted with evident marks of satisfaction, and took their leave with the promise of returning very speedily.

Towards evening Captain Billings returned, leaving the rest on shore. In the night a thick mist arose, which did not clear up before the close of the next day, when the boat arrived, but six sailors were still left behind with the baidar, which they had ubtained in exchange for pearl-enamel. We were very uneasy at their stay, apprehending lest some accident had happened; but were relieved the next morning from our anxiety by their safe return. They assigned the darkness as the reasn of their staying out, having been unexpectediy overtaken by night, and having sought in vain for the vessel.

During our anchoring here, we observed that the current of the sea along the shore from Norton's-Bay to west-south-west, makes mostly half a mile, and sometimes a mile and a half in man bour. 
On the Sist we weighed anchor and bore up to Fledget island, called by the Americans Ajak. At noon we observed the latitude to be $64^{\circ} 34$, the longitude $193^{\circ} 31^{\prime}$, and the island Ajak to be five miles from us to the south-west $67^{\circ}$. In the afternoon the wind dropped entirely, and we came to an anchor in ten fathoms water and a pebbly bottom, at a distance of two miles from the shrre of America. Here the same Americans visited us as had come the day before, and with then many others whom we did not know. They brought us similat articles, and carried, on a brisk tade with our sailors. Glass beads were in the greatest request with then, for which they paid most liberally. Captain Billings bought a single-seated baidar for one row of them only; and the purchaser concealed them immediately they were in his possession, probably from an apprehension that we might repent of our inconsiderate bargain, and wish to retreat. Whis buidar was as larye, and constructed in the same manner, as that of the Kadjukers, only with this difference, that it was not covered with the hides of the sea-lion, but with those of the walus, which, on account of their thickness, had been parted three times.

A north wind springing tp toward evening we weighed anchor and steered between Ajak and Cape Rodney, on which we found several summer jurts crected in different places. On the first of August we observed our latitude at noon to be $60^{\circ} 4 \mathrm{O}^{\prime}$, and longitude $192^{\circ} 27^{\prime}$. In the afternoon we saw, to northwest $3-4$ ths west, the nowntainous island which is called by the Americans Okiben, but by the Engligh King Lstand; and in the evening were two miles distant from it. It is five miles in circumference: from the inarcessible rocks with which it was girt and the widnets of its aspect, we judged it to be uninhabited, but afterwards we learned from the Tschukshens that some families actually resided there.

On the morning of the $2 d$ we descried through the mist a small isiand, the smallest of the Needle isies, lying in Behring's strait, and at noon we came in sight of the other two. The tirst was 21 miles from us to the north-west, $15^{\circ}$; the second 20 miles, to north west, $4^{\circ}$; the third 15 miles to the north east $14^{2}$. The first two are mountainous, the latter has the appearance of a small hill. We calculated on latitude at $65^{\circ}$. $4^{\prime}$, longitude $190^{\circ} 29^{\prime}$; the depth was 28 fathoms, and the bottom sandy.

On the 3d we laveered with a north wind in Behring's Strait, betwixt the north eastem cape of Asia and the north westem cape of America. Both shores are mountainons and woody, and the mountains occasionally covered with snow.

lu the afternoon of the 4 th we laveered so far to the north as 
to be able to put into the bay of St. Laurence. At its cntrance we saw on the right bank of the rivulet Lragma, some summer jurts of 'Ischulschens crected. We ran four miles and a half into the interion of the bay, and came to an anchor in six faw thoms water, and a sandy botton, on a level spot of the right shore, where the plank hits, or summer-jums of the Tschukschens stood. No sooner had we cast anchor and began to furl on sails, than we discovered sone Tschukschens putting of towards us in a large baidar. They did not approach very near, but beckoned tis to the shore, shewing us a paper done up in the form of a letter. We invited them on board by one of our Cossacks, who spoke Korakish, but either not understanding him, or fearing us, they went off. Upon this Captain Billings, Docto: Merk, and $I$, went on shore, and were met by the inhabitants with great ficudship, who invited us into their jurts, at the same time requesting us to leave our swords in the siloop. "We," said they, "come to you as miends, withont any arms, but you must do the same." Their request being complied with, they conducted us into their jurts, where they, delivered us the folded paper which we had seen in their hands. It was a report to Captain Billings by Sotnik Kobelew, who had been sent in the year 1787 from the fortress of Nishne-Kolymsk, with the interpreter Datrkin, in order to amounce our coming to the Tschukschens. Kobelew observed, that he had waited in company with the Reindeer 'rschukschens here, and on the eastern cape, for the arrival of our vessel, from the 28th of June to the 20th of July; but his companions not choosiug to stay any longer, he had been obliged to go with them in a baidar, by water, to the island of Kalutschin, in the Frozen Ocean, where the Tschulschens had left their reindeer at their principal settlement. He added, that they should stay there till the 15 th of August, and after that go with the reindeer into the interior of the country. Kobelew made no men. tion of the interpreter Daurkin, concerning whom we enquired of our Tschukschens, and received for answer, that he was living - with the Reindeer 'I'schukschen Imlerat-Kirenjew, who ras depasturing at no great distance from this place. They promised to give him intelligence of our arrival. 


\section{CHAP.VII.}

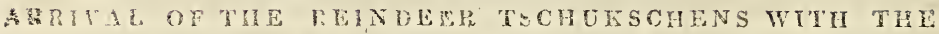

MTERPILTER DAURKAN.- BESCRIPTION OF THIS PROPLA.-ENTERPRIZL OF CAPTAIN BILLINGS, AND MIS DAPAXTULE WITH THE TSCHUKSCHENS TOR THE RIVER KOLYMA.

\section{Th"}

1 OWARDS evening the interpreter Dan kin came with serenty-two large baidars full of Reindeer Tschuschens, and their Troi Imlerat Kirenjew. We soon gained the confidence and good-rill of our new guests by civility and suitable presents. They hauled their baidars on shore by the side of our ressel, and converted them into dwellings in the usual manmer, visiting us regularly every day, and observing every thing with looks of extreme curiosity and admiration. But nothing could equal their astonishment at witnessing the effect of our guns, which we fired with balls into the sea for their entertainment. In the mean time they carried on a brisk trade with us; bartering their fox-skins, walrus' teeth, arms and utensils, for tobacco, enrmel, and beads. Both the men and women of this nation are mostly of the middle stature; there are, however, some taller individuals among them. They are all stout built, having a healthy appearance, with an open physiognomy, not so savage as is tisually found among rude nations. In their features they resenble the Americans of Cape Rodney, cutting their hair in a similar mamer, and wearing similar clothes: however, the men do not, like them, adorn their lips with pendant bones. The women, on the contrary, puncture several parts of their body in rarious forms, particularly two semicircles on both cheeks, which unite in cross directions. They bind up their hair in two guenes, hike the female Russians, but do not twist them in a tuft on the crown, or cover them, but let them hang loosely behind. The male and female dress is very similar, consisting of vests and trovrsers; but the upper vest of the female is somewhat shorter, and the under one is fastened to the long trowsers. In the dry season of summer, they wear alaschas or short boots of rowlng, or tanned rein-deer-hides, but in damp and ramy days they put on long torbasas, or wide and long boots without heels, made of tamed sea-dog's shin. 
Like the Tunguses and Koraks, the Tschukschens are divided into Reiudeer or nomadical Tschukschens and settlers. The former are the most numerous, and wander from place to place; but the latter, who are only few in number, are altogether poor people; who having by some misfortune lost their reindeer, their only wealth, are compelled to fix their abode near the sea, and from thence to draw their subsistence. They live all the winter in mud-jurts, and the summer in huts of planks, and obtain an ample provision from the water. They prepare, not only for themselves, but for the Reindeer Tschukschens, the fat. of fish and marine animals; sew summer shirts and covering for the feet out of reindeer's entrials, for which they receive, from the latter, upper garments and winter covering for the feet; reindeer's skins, and others, fetched from Ischiga; also tobacco, and other Russian commodities.

The Tschukschens, thus stationed, keep dogs for want of reindeer for their winter excursions, which they harness to sledges made of walrus teeth, similar to the Russian tschunkas, which are without any back or sides, and consist only of the sledge and some cross-beams nailed over.

The dogs here resemble those of Ochotsk, but are rather smaller. Six or seven are harnessed abreast, and so close to the sledge, that they may be reached with a whip which the driver swings round either to the right or left, as he would have the dogs go.

In the summer they paddle about the sea in large baidars, commonly from 20 to 25 feet long, 4 feet broad, and $2 \frac{\pi}{2}$ deep. The hulk is made out of the floating wood from the sea, very, nicely cut out and joined together with strips of whalebone; and the whole is covered with walrus hide, doubly or trebly split, in proportion to its thickness. A baidar, when quite ready, is so light, that two persons may carry it with convenience. The Tschukschens not only coast in them along the shore, but pass over to the neighbouring islands, or even through Behring's strait to America. As it is very unsteady, it is mostly moved by oars rather than sails; and whenever the latter are used, extended bladders are tied on the sides to prevent it from oversetting The baidars which we saw at Cape Rodney resembled these in every respect.

Both the wandering and stationary Tschukschens are divided into very small communities consisting only of families of one common origin. They have no civil authorities, or chiefs; but in every such community the richest, or the father of a numerous family, is the most esteemed. They show him no other deference than to receive his good council, or be deterred from evil proccedings by a warning; but he has no power to enforce his 
admonitions by punishments. With such an anarchy it would certainly be a subject of surprise, that this people should have hitherto obstinately maintained their independence against frequent and considerable bodies of Russians who have been sent against them, if we had not already seen the extraordinary effects which a love of liberty has in producing union among the members of a community.

The principal cause of the campaigns against the Tschukschens, was a neighbouring people, the Koraks, who being at perpetual enmity with the former, and yet unable to stand against so powerful and valiant a foe, were compelled to put themselves under the protection of the Russians, and on that account to become tributary to the latter. With the aid of so powerful an ally, the Koraks sought every opportunity of urging their complaints against the Tschukschens, and often induced the Russians to take up arms against them upon frivolous and false pretexts. Whenever any reconciliation took place, the harmony which succeeded was but of short duration, being generally interrupted by some charge of the Koraks. Peace and war, therefore, commonly depended upon the judgment of the commander at the fortresses of Anadyr and Iscinga; but on the demolition of the fortress of Auadyr, and the introduction of a government at Ischiga, these differences with the Tschukschens having been compromised, we tried to allure them by kind treatment, and found our efforts crowned with success. They now come yearly to Ischiga and Mohine Kolymsk, in order to deal with the Russians, upon which occasion many of them also bring their japak or tribute.

This commonly takes place at the close of February, or the commencement of March; and when their trade is finished, they go off immediately to the Frozen Ocean, and spend their whole summer in catching fish and sea-animals, for which they have baidars that are not only fitted for coasting, but for more remote excursions. They very often pass Behring's strait in these, attack the habitations of the savage Americans, and, after plundering them, carry away many prisoners to their homes.

Much as the Tschukschens excel all their neighbours in valour, they are much inferior to them in civilization of manners. They not merely kill their new-born infants for any defect, but the children relentlessly dispatch their parents on account of $1 \mathrm{~m}-$ becility or disease; nay, it often happens that a sick person will solicit the favour of being killed, with the idea of dying more heroically than if lie follows the course of nature, for they seem to think that a natural death is only fitted for old women. They are vindictive and cruel to those who offend them, without regard to relationship or friendship, of which they gave us an instance 
themselves of a son having killed his father for charging him with cowardice and awkwardness.

Superstition and superstitious rites are less frequent among them than among other savages; but they have some solemnities, particularly at the burning the bodies of the deceased; which as I had no opportunity of witnessing during our short stay, I am not able to describe. Nor can I speak more circumstantially of their religion, having perceived no traces of any thing like divine worship. We found, indeed, some wooden and bone images among them, on which they had put clothing, but at the same time held them in so little estimation that they bartered them for mere trifles. At Billing's request they gave us a specimen of their dancing, which was very similar to that of the Americans at Cape Rodney, with this difference only, that they hopped more, and sprang from place to place. After they had done dancing, the men seated themselves on the bare earth, and the women also, but in a semicular line, drawing their vests off the right shoulder, and thus exposing the arm that was punctured in various forms. They then began their song, to which they made a suitable motion with the right arm, one time as if they would take up something from the ground, and another time as if they would lay it on their knees, and then again bending their head and body to one side. The tirst in the rank took the lead, and was followed by the rest, who, keeping their eyes fixed on her, strove to imitate her movements in the exactest manner possible:

The main object of our visiting these shores, was the making a second experiment to penetrate into the Frozen Ocean, from Behring's Strait round the Schalazkish promontory. We had resolved on this undertaking, but were deterred from putting it into execution by our friends the 'Tschakskens, who constantly ramble along the shores of the Frozen Ucean; and assured us, that it was utterly impossible to advance in vessels of any magnitude, they themselves being sometimes unable to proceed in their baidars, although they kept as close as possible to the shore. We gave fuller credit to this assurance, from remembering that Captain Cook, and after him Captain Clarke, had made unsuccessful efforts to penetrate to the west through the Frozen Ocean. We accordingly renounced this idea, and Captain Billing resolved on encompassing the shore of this sea, and surveying the Schalazish cape, in company with the $T$ schukschens and a small party of our men. To this end he persuaded the Troka Imlerat Kirenjew to carry him, with his rein-deer, to the fortress of Nishne-Kolymsk.

On the 13th of August the captain resigned over the command to me, and repaired, with the Tschukschens in fourteen G 2 
baidars, to the bay of Metschigman, in the vicinity of which was Imlerat's settlement. He took with him Dr. Merk, his assistant Meir, the boatswain Batakow, the first surgeon Lehmann, the interpreter Daukin, and three hunters, leaving me orders to survey the bay of Anadyr, to proceed from thence to Unalaschka, and winter there; in the spring to return to Kamtschatka; and after having examined the sea between the Kurilian islands, to leave the vessel in the harbour of Petropaulousk, and go with the men to Ochotsk.

\section{CHAP. VIII.}

DEPARTURE FROM THE BAY OF ST, LAWRENCE TO UNALASCHKA. - ARRIVAL AT CAPTAIN'S BAY. - IMPOSING A TRIBUTE ON THE ISIANDERS.-ARIRIVAL OF THE TOJA OF THE ISLAND ATCHA, AND THE ALEUTIANS OF THE ANDREJANOW ISLANB.-SEA-LION CHACE.SCURVY AMONG THE MEN.

T

HE departure of Captain Billings was immediately succeeded by my own. I weighed anchor the next day, even in a perfect calm, and was towed off between the narrow cape and the exterior sandbauk. The depth of this place amounted to $2 \frac{1}{2}$ fathoms. On going round the cape, a west wind arose, with which we managed to get under sail. The depth increased to 5 fathoms, and the bottom was sandy. After passing the shallow's we lay-to for a time.

We did not observe any tide while we lay at anchor.

On going again under sail we ran straight through the bay of St Lawrence. The depth in the centre was 25 fathoms in a sanily bottom. The breadth of the mouth, from the north-east to the south-western cape, amouits to 11 miles. On the shore of this latter we discovered, at the foot of the mountains, and in the vicinity of the brooks, the habitations of stationary Tschukschens in four different places.

Two miles further we stood round the rocky mass, forming the soutb-easten point of the promontory at the mouth of the bay, and kept along the shore first $8 \frac{3}{4}$ miles to the west, and afterwards $4 \frac{1}{2}$ miles to west-south-west. The depth amounted to 15,13 , and 10 fathoms, with a gravelly and sandy bottom. The mountairs grew more level, and were intersected by various clefts. The coast that immediately bounded the water was an entire flat, At a distance of five miles a-head of us we discovered the point of a store, on which was a large settlement of the Tschukschens. From this point commences the bay of Metschigmena, beyoud which the shore bends to south-south-east, running onward into 
mountains, and occasionally declining into a perfectly level surface.

On the 15 th we calculated the latitude at $64^{\circ} 37^{\prime}$, the longitude at $188^{\circ} 11^{\circ}$. The depth was 12 fathoms, and the bottom pebbly. In the afternoon the weather clearing up, which had been for some time hazy, we discovered to south-west, at a distance of 17 miles, a mountainous shore, into which the two bays, Geljagin and Ketschekeyum, penetrated. According to the account of the Tschukschens, there were three islands at the mouth of the former; but we could distinguish only one of small magnitude, probably owing in part to the mist which was not entirely dispersed, and in part to the nearness of the two first to the shore. At seven in the evening we descried to north-west, ${ }_{7} 6^{\circ}$ a considerable settlement of T'Tschukschens, and towards midnight we were opposite to the southern point of Tschukotskoi Noi, and lay-to till the morning, in order to examine it more narrowly.

On the 16 th a violent wind and heavy mist arising, we found it necessary to continue lying-to, and remained till the 18th off the shore of the above-mentioned bay, in the constant expectation of clearer weather; but no change taking place, we resolved on steering for the island of St. Matthew, in order to recruit our almost exhausted stock of wood from the floating logs that pass that shore in great quantities.

On the 19th the wind changed, becoming first southerly, and afterwards south-easterly; the mist likewise dispersed, and opened to our view the island of Clark, or St. Lawrence, called by the Tschukschens Eumugjen. The Tschukschens pass over to it in their baidars, in order to exchange their baidars and large whale-bone with the Russians for various trifles. At noon we observed the latitude to be at $63^{\circ} 23^{\prime}$, the longitude $136^{\circ} 39^{\prime}$.

When we first came to an anchor off this island, we funcied we saw through the mist two small islands, which must have been only mist; for after the most diligent search in clear weather, I could discover nothing. I should conceive some of Lieutenant Sinde's islands to have been of a similar nature; and it is most probable for Captain Cook to have been in like manner mislead, for Anderson's island, another lying to the nortl of Clarke's, were not to be found in the places assigned them, although we examined the different parts in perfectly clear weather.

In the afternoon we approached St. Lawrence's island, the first and most conspicuous part of which, its north-eastern promontory, appeared to be a small distinct island, until, on a nearer survey, we found it united with the former by a plain. 'The English mariners are of opinion that this is the cape to which Conmodore Behring gave the name of St. Lawrence; but I 
consider it more probable for him to have taken the mountains of the large island, which are infinitely higher, and more conspicuous, for this cape; for which reason the island is more entitled to the name of St. Lawrence, than Clarke.

With a fair east and north-east wind on the 20th, we got near the island of St. Matthew, which the mist concealed from our view. In the evening the wind grew stronger, and continued rising all night, so as to be actually stormy towards morning.

On the $22 d$ the wind abated; but the sea running high, we were driven to south-west. Till the 26 th I waited in vain for a change of weather, by which I might draw nigh to the shore of the island; at length our very reduced stock of wood obliged us to turn our thoughts to some other resource, and we accordingly resolved on steering for the island of Unalaschka.

On the 27 th we stood off the Pribylow's islands, and the next morning we passed the southernmost of them, St. George's Island. At 9 o'clock it was 21 miles distant from us to the north half-east, our latitude being $55^{\circ} 57^{\prime}$ and longitude $191^{\circ} 6^{\prime}$. On the morning of the 29th we came in sight of Unalaschka: at noor the cape between the place Weselowsk and the mouth of the Captain's-haven, was 38 miles distant from us, to the southeast $80^{\circ}$; from whence we perceived, that we had calculated our latitude from Lawrence-bay always 46 miles too easterly.

'Towards evening we came to an anchor off the eastern side of the island of Amaknak. The day following we proceeded as far as the village llluluk, and took up our former station there. Here I learnt that our other vessel under the command of Captain Hall bad run into this bay, and after a stay of 13 days for victualling and watering, had put to sea again.

Perceiving that half a mile from our anchoring-place to the south-west of the island, there was a better station for our vessel on the other side of a little island, I accordingly proceeded to the spot, and lay at cable's length between two shores.

Our first colicern now, was the providing ourselves with a sufficiency of wood, for which purpose we daily collected the floating logs from the adjacent parts, and conveyed them to our ship in baidars.

On the $2 d$ of September some Aleutians informed me that they discovered a single-masted vessel at sea, towards the westtern shore of Captain s-haven; but not being able to give me any farther satisfactory account, I mounted the summit of the mountain on the islanda Amaknak, where, through a telescope, I descried a vessel, which, from its equipment, could be no other than the newly-built cutter under captain Hall's command. I immediately went in a sloop to it, and was welcomed by the whole crew with the most heartfelt delight. According to their own account, 
they had been in the track after us during the whole summer, but had been prevented putting to sea until after the time appointed for meeting our vessel. It being a calm, the new vessel, which had received the name of Tschernoi Orel (Black Eagle) from its builder, came to an anchor first near the western shore of the Captain's haven, close by the village of Natykinsk, from whence it was towed in the evening alongside the Slawa Rossii.

On the 3d of September our officers held a consultation on the properest place for passing the winter, in which it was unanimously decided, that, in consequence of the distance of Kantschatka and the lateness of the season, it was most adviseable for us to take up our abode off Unalaschka, and at the same time to remain on board our vessels. Captain Billings had, indeed, recommended for the crew to be dispersed among the different villages of the Aleutians; but, independent of the burthen which their support would have been to a people oftentimes unable to maintain themselves, the vehement and tempestuous winds which at present raged, made it altogether impossible to find any secure anchoring-station. We therefore determined, for the sake of saving our present stock of sea-provision, on curtailing the daily allowance, and on using every effort to recruit ourselves, which circumstances would admit of.

In order to lighten the vessel and preserve our stores, I had a sort of magazine erected of poles, which were covered with thick grass instead of planks; and for a bakehouse as well as seperate dwelling for the sick, had a jurt built on a shore of floating wood.

On the $12 \mathrm{th}$, we proceeded to execute that part of our commission, which required us to number the inhabitants of the places subject to the Russian empire, to regulate the Japak or tribute in future to be levied, to acquire the good-will of the islanders by presents, and confer honorary gold, silver, and copper medals, in the name of the empress on the most respectable. We profited by the opportunity which presented itself on that day, when the Aleutians were collected together, to receive the presents promised them by Captain Billings for the preparation of dry fish, berries, and roots. We accordingly distributed rewards among them, and dismissed them with still greater promises. They readily acceded to the tribute im. posed upon them, and engaged to discharge it at the commencement of winter, both for themselves and for all who might go to the chace, taking upon themselves the management of the whole matter. Hitherto the Japak had been imposed only on two or three, selected by our hunters, and on that account called Jassashnas.

By the middle of September we had our magazines construct- 
ca, into which our provisions and stores were transported out of the ships.

In caln weather the Aleutians brought us stock-fish and roach from time to time. The inhabitants of this place catch their fish on the western shore of Captain's-haven, with tackling of whalesinews or thin sea-cole, to which they tie a bone or iron-hook, sticking on it a piece of fish, or the root of Angelica, or some other herb of a particuler description fetched from Alaksa, which has a powerful smell.

For their fish, we made the Aleutians some trifling acknowledgments. Tobacco, fine needles, and goats-hair were the prineipal objects of their choice. With the latter they decorated their vests, making it also serve instead of thread in puncturing, for which they likewise use white hair from the tails of horses, and rein-deer hair. They in like manner shewed a partiality for white and red enamel, with which the women adorn their clothes, being very much pleased with the Russian dress, particularly the jackets of nankeen, the shirts, trowsers, and handkerchiefs.

On the $2 d$ of October we had so violent a storm, that our cables were broken, by which we were fastened to the shore. .

At this period we were visited by the chief troja of the island Atclia, of the name of Pankow, who came to us from Unimak in a large baidar of the Andrejanows islands. He had been on visit to his relations in Unimak, and at the same time had distributed the regulations which he had brought with him for all the islanders in the year 1789, when he went to Kamtschatka with a merchantman.

This troja wore a vest of light red cloth with gold fringe, and a velvet cap, presented to him by her Imperial Majesty. He spoke tolerably pure Russian, and discovered in his conversation a superiority of knowledge and discernment over all the other trojas. We learned from him the number of inhabitants on the Andrejanow islands, in each distinct place, as also the particular number of males. He was attended by the trojas of the abovementioned places, with whom he consulted about the tribute. they had each to pay. In our turn we distributed medals among them in the name of her Imperial Majesty; assigning to Pankow one of gold, with several other presents.

Pankow was accompanied by 25 Aleutians from the Andrejanow Islands, 14 of whom were in a large baidar, and the rest in small single-seated baidars. In their passage through the very broad strait between Sigram and Amnuchta, they were so tossed about by a storm, as they informed us, that they were obliged to lighten the vessel of its tackling and stores, and were driven to and fro for forty eight hours, on which occusion one 
inarin a small baidar was separated from them, and had not been heard of since.

In a violent wind and a swelling sea, the Aleutians are obliged to keep in one station as mich as possible, for which reason they tie all their baidars in a row to one another; and that they may not be dashed together by the waves, they put bladders in the spaces between, and point the head of their barks against the waves until the wind clanges.

The Andrejenow Aleutians are perfectly similar to those on nur island, both in appearance and mode of living; having even in their language no other visible difference than what was occasionally to be observed in the position of the words and their accentuation. The dress of both males and females was perfectly alike. The women wear the same ornament in their ears and nose, with this single difference, that the bones which the former stick in the under lip are much smaller, and the holes are pierced wider apart on the side of the mouth. In the middle of the cheeks they puncture a little black double circle, obliquely over the middle of the forehead a double line, and over the nose betwixt the eye-brows two little crooked stripes.

In the beginning of October, the Subaltern Chudakow was sent out to survey the Aleutian Islands, upon which the Aleutians also set off from the Andrejenow Islands for Umnak, where they intended wintering.

At the close of this month the Aleutians began the seabear chace, which continued till November. These animals return from the northern to the southern countries, and in their course enter the bays of this island, upon which the Aleutians purswe them in their baidars. They know pretty accurately the spot where they rise up out of the water, and two or three men to a bear plant themselves in a convenient position for casting their darts at him, as soon as he makes his appearance. Thus by repeated wounds with their darts every time he rises, they at length completely exhaust and cripple lim; but that he may not sink immediately on receiving the mortal stab, they afix bladders to their darts. He only has a right to the skin of the animal who inflicts the first wound.

The chace of otters and other aquatic animals is subject to similar laws. The first successful clarter receives half the skin and the entrails, and has besides the right of assigning the other half to any one of the hunters he pleases; the second successful aim entitles the person to the neck, and the remaining entrails; the third takes the bladder; the fourth and fith can claim the fore feet; the fifth and sixth the hind feet. The fiesly is shared equally among all the parties concerned.

At the commencement of the year's chace, the person to SARYTSCHEW, VOL. 11.] 
whose share the first sea-lion falls, distributes his portion of flesh among all the Aleutians of his place ; but they are obliged to return hin all the bones, which being collected together, are thrown back into the sea.

The commencement of the sea-lion-chace terminates the fisliery, the weather being usually too cold, and the winds tor vehement. The favourite food of the Aleutine is the flesh of sea-animals, which, when consumed, is supplied by shell-fish, roots, and sea-wort; some of them indeed, in summer, lay bye dry fish, roots, and fat, which is, however, generally in too small quantities to last any length of time. 'The sea, therefore, remains, at all times, their grand resource ; one while supplying them with an abundance of fish or animals for their pursuit, and another time casting on its shore many delicacies which require no labour to obtain. In this manner the in habitants pass an easy life heedless of futurity.

In the evening of the 5 th, a strong wind rose from the west, which tore the cable of the Slawa Rossii, that was no sooner supplied by another than it was instantly torn again. 'The storm lasted three days and nights, and burst forth from the clefts of the mountains with such impetuosity, that the boats and empty casks, lying on the shore, were rolled down into the sea.

Hitherto we had procured fuel from the willows that grew on the shore of a brook that ran into the bay of Natykinsk; but in consequence of a heavy fall of snow, and the brook being frozen, we could not float any more willows down the stream, but we found others at the farther extremity of another brook near the village of Mluluk, whither we sent our men after it on foot; an esercise that served as a very efficacious preventative against the scurvy, which was beginning to make its appearance.

The 19th, being calm weather, the Aleutians went fishing at our request, but caught only two shell-fish.

On the 2lst, we dispatched two of our hunters to shoot fowl. Three of them put themselves into a treble-seated baidar, with the view of crossing the strait; but were scarcely off from the shore when a sudden squall upset their unsteady bark, and dislodged its contents into the water. Two of the men saved themselves, but the third was drowned. "The complaints of our people respecting the smallness of their allowance becoming too urgent, we were obliged to give them their ordinary portion of peas, butter, and meat.

At the close of December the scurvy had increased the number of our sick to twelve. We strove to afford them all possible assistance, by procuring fresh food, for which pur- 
pose six or seven shooters were daily sent ont after wild fowl. On lucky days they usually brought from three to six birds of different sorts, as urilas, sea-ducks, mews, wild-geese, and occasionally a woodcock, or some other land-bird.

On the $2 d$ and $3 d$ of January the weather was hazy but calm. Some Aleutians then went again to fish, and brought us twelve stock-fish and two roaches, each of which weighed two pounds and a half. In the middle of January our pa. tients with the scurvy were increased to the number of twentythree.

The high wind which blew from the 19 hl to the 25 th drove a whale to the western shore of Captain's-bay, and afterwards threw it on the island of Uknadok. The islanders gave us information of it, enquiring, at the same time, whether we were not in want of oil. We ordered twelve puds for burning in our lamps. Although the fish was only eighteen feet long, it proved extremely serviceable to the Aleutians in their approaching scarcity, and was shared among all the inhabitants of the surrounding villages.

On the 8th of February, we had still twenty-three sick of the scurvy, and two dead.

\section{CHAP. IX.}

DEPARTURE FOR THE NORTHERN SIDE OF UNALASCHKA. -ARRIVAL ATTHEVILLAGEOFMAKUSCHINSK.-GAMES OF THE ISLANDERS.-BAYS ON THE WESTERN SIDE OF THE ISLAND.-CURE OF A SICK WOMAN BY A SHAMAN.ATROJA ACTING AS SHAMAN.-RETURN TO THE VESSEL。

A CCORDING to the information of some Aleutians, there were some beautiful bays on the western side of Unalaschka, which, as they had hitherto been unnoticed by any one, I took upon myself to survey and describe. I accordingly set off on the 13 th of February, in a treble-seated baidar, attended by a few islanders in single-seated ones. I had but one sailor with me, and the troja of Illuluk, baptized by the name of Elisei Vupyschew, who spoke tolerably good Russian, and served as interpreter. I was obliged after the manner of my companions to draw on an upper garment of fishes' entrails, to put a wooden hat on my head, and take the oar in my hand. My compass was fastened before me in a direction that I could use it at pleasure; and the sailor who was in a small baidar, carried the lead for sounding as I desired.

As soon as we were clear of the western shore of Captain'sเ 2 
- haven, we stood to the north-west along the steep rocky shore of the northern side of Unalaschka, as far as the open bay of Weselowsk, which penetrates three quarters of a mile into the island. On the shore of a little brook which discharges itself into it from a cleft in the mountain, lies the settlement of Weselowsk, consisting of only two jurts, inhabited however by thirty-one persons of the male sex. Opposite to this village, a rocky islet rises in the bay, that is very distinctly observed from the sea, being much more prominent than the interior flat shore of the bay.

We spent the night in this place, and pursued our course in the morning. The shore continued to be one rocky steep towards south-south-west, as far as the other bay Sachtupik, which extends for half a mile into the interior of the island. It receives the waters of two brooks from the mountans, the foot of which forms the depressed gravelly shore.

Eight miles from Weselowsk we passed a volcanic crater, called by the Aleutians, Aijagin. It is higher than all the other mountains of Unalaschka, with a summit more level than pointed; that on the southern side of the island has the appearance of being almost flat; all eruptions have long since ceased, and nothing now remains but occasonal smoke. Earthquakes are likewise now very rare, which were formerly frequent and so violent as to overturn jurts and pendant rocks. On the summit of this crater the Aleutians collect sulphur and lava; from which latter they make points for their darts.

The weather this morning was very dull, attended with only. a gentle east breeze, that strengthened towards the afternoon, and occasioned a vehement surge. The Aleutians pursued their course with the most perfect tranquillity and unconcern, while I was in no small trepidation, fancying that every billow which approached me would inevitably sivallow me and my hittle bark.

- Nor were my fears without foundation, for though the inhabitants are very expert in managing these boats, and preserving the exact equilibrium with their oars on the approach of every wave, yet such is the smallness of these conveyances, mine not being more than a foot and half broad in the middle, that the slightest error in guiding them may be, and often is, attended with the most serious consequences.

Fifteen miles from Weselowsk the shore became very sandy, forming, b y a curve inwards, a sort of bay, which received the waters of a brook from the neighbouring mountaius. Farther on, the shore winds to the norh-east, and finally to the east, terminating with the village of Makuschinsk, about two miles and a half distant from the curve before-mentioned, and lying at the mouth of a small river, formed by three lakes, and united by small water-falls. In this river much hump-backed salmon and 
similar fish make their appearance about the beginning of May. There are 45 Aleutian inhabitants in this village, who are distributed in two large jurts.

During a stay of three days, I found the games here which are usual among these people, and which continue through the winter until the beginning of spring, or until the appearance of the whales. Their orign is ascribed to the Shamans, who assure them that the spirits are pleased with such performances, and will, in return, send plenty of whales on shore. The performers wear masks, resembling the faces of the spirits which have appeared to the Shamans; and, although these men no longer possess the inplicit confidence of the people, the Aleutians always celebrate the arrival of a fish with these games. The person first making the discovery announces it by wearing a narrow fillet on his head, and has a right to half the entrails, skin, tongue, and sinews. The rest is divided by the trojars of the village among the other Aleutians.

On one of the days which I passed here I witnessed the following celebration of the above-mentioned games:- There poles were placed horizontally between the beams of the jurt, the first about three feet below the upper opening of the jurt, the second about twelve feet lower, and the third about nine feet below the second, and about four feet from the ground.

The Aleutians assembled from the different villages then swing themselves up to the opening, during which a perpetual clamour is kept up by the shouts of the people at whose jurt it takes place, while those who miss their aim and fall to the ground are saluted by the spectators with loud peals of laughter. As soon as this is concluded, and the guests are seated, the dances commence in the following order :-First, two boys in a state of nudity, who were followed by men with drums fancifully decorated with caps on their heads, girdles round their loins, and bands on their arms and feet; afterwards|females, two and two, having their heads encircled with binders embroidered with goat's hair, flourishing bladders of birds' skins, and dancing to the drums; then a second string of females carrying arrows; and finally a train of men in motley masks, with wide streaked mouths, and on their heads a sea-dog's face. Some few who were seated struck violently on drums, to which they sung the following verses, Which, although translated to me, I by no means understood:

What shall I do?

As it appears to $\mathrm{mc}$,

That I shall do. 
Then came another mask, with wide extended mouth, and shepherd's crook, singing as follows :
O what knavery!
O what roguery!
Thou, O Ammech!
Hast made the world.

A third mask, having lost a left eye, sung the following;

In the midst of Alaksa,

Is Agmagaluk's jurt ;

'Tis that which we sing.

These men were followed by female masks, who seated themselves by the man with the sea-dog's face, before whom a few other women danced with dishevelled hair, carrying beards of sea-lions in their hands, occasionally pointing to the mask seated in the middle. They sung the following verse:

\section{The hellish island Sakchadok \\ Contains the arrows we must not forget; \\ Yet why should we remember \\ That which brings no good?}

And thus ended the piece. I had also an opportunity of seeing the dances of some of the Andrejanow islanders (who were spectators of the above performance), which differed much from the others. 'The men took off their upper garments, dancing in succession one after the other in shirts and trowsers; having on their heads caps, embroidered with long narrow points, projecting forwards, curved towards the top, and decorated with goat's hair. A sea-hound's skin, two sea-lions' bladders, and a cloth, were thrown before the dancers. When the Aleutians began to sing, the dancer took in each hand a bladder, which he held so as for them to hang down to his elbows, and then began to dance, nodding and tossing his head to the sound of the drum; after which, throwing down the bladders, he took up the the skin, and swung it aloft several times, as if to exhibit it to the company; then threw it down, and seizing the cloth, danced with it as before, holding its extremities in his hands; and finally, taking a stick, imitated the action of rowing a baidar. They say this dance is expressly invented for the purpose of representing in a ridiculous point of view the vauntings of their companions, concerning their catching marine animals; the bladders, the seal's-skin, and cloth being emblematical of the spoil which the hunter triumphantly exhibits to view. The women array themselves for the dance in an upper garment, resembling the parka of the men which they confine with a girdle, tying round their heads a binder, like that of the native Aleutians, and carrying on their backs an arrow with an intlated bladder. The lady thus equipped, approaches the circie of men, who are all seated, 
and kneels on a grass mat in the midst. When the song commences, she begins to move, and gradually rises with her hands both confined in her girdle; she then takes the arrow from her back, and, raising herself on her toes, in this attitude dances, without leaving the spot, at the same time suiting the movements of her head, and those of the arrow she holds in her hand, to the sound of the drum.

On the 17th the weather being fine and sun bright, I commenced my observations from the promontory of the place, and found our latitude $5.3^{\circ} 5 \mathrm{l}^{\prime}$. A small cistance from the village $\mathrm{I}$ discovered a warm spring issuing from a cleft in a rock, which is, however, ouly visible at low water, being at other times sholly covered by the stream.

On the 18 th the weather was calm enough for me to pursue my course; previous to which I took a survey of Makuschinsk. The shore leading to it extends in rocky projections towards south-east $60^{\circ}$; the entrance of the bay is about 23 miles wide, lying to the north-east $55^{\circ}$. At a distance of about 220) fathoms from the northern side of the bay towards the south-west are two high projecting rocks; 60 feet from the rocks the water was not more than seven fathoms, although in the middle it was so deep that our lead never once reached the bottom. The whole bay is nine miles and a half in length. At noon we were off the left shore, near Ikschaktak's bay, in lat. $53 \circ 46^{\prime}$. In the afternoon we ran in and found the opposite shore, five miles distant from the mouth, divided by a neck of land into two parts, one called Udamak and the other Maganach.The first extends to south-east four miles and a kalf, having-in its centre two small islands. On the left hand, the space between the shore and the nearest island is about the third part of a verst in the centre. The water is 32 fathoms deep, with a gravelly bottom : the roarls are about a verst in width, and so deep that a line of fifty fathoms could not reach the bottom. 'The other half, or Maganach bay, extends itself two miles and a half towards the south; it is very deep at the entrance, but three quarters of a mile farther shallows to fifty fathoms, and continues to become more shallow as you approach the opposite shore. A mile and a quarter from the island, both the shores approach each other, and form a road about half a verst in breadth, which leads to an oval basin, a mile in diameter. This basin also receives a stream that descends from the mountains. In the centre it is seven fathoms deep, and at the mouth 25, with a muddy bottom. We took up our abode for the night on the first island, where we found a hut constructed of whales' bones, in which, the Aleutians, from Makuschinsk, 
usually reside during the autumn, for the purpose of catching sea-bears, which run into the bay at that season:

On the following day we left this place, and anchored agair off the village Akmaga, four miles from the bay Makuschinsk. 'This village lies near the shore, in the vicinity of a brook which' flows out of a lake, and has seven male inhabitants. Having passed the night here, we proceeded onward, and passed two bays which penctrated three miles into the island to south-east. They appeared unsheltered, and not well adapted for an anchoring-place, on which account I thought it needless to enter them. A range of high rocks extend themselves for about half a mile to south-west, beyond which the shore winds to south-east and south towards a bay, called by the Aluetians Alukoo, and by the Russians Makrowsk; its entrance is about a mile and a half wide, defended on each side by steep rocks, and penetrating towards the east about three miles and three quarters, and then winds to the south, where, although it is sheltered from the winds on one side, is still an insecure station from the rough rocks and numerous cliffs on its shore. Two miles and a half beyond the promontory is another bay to the south, called Koshiga, open towards the west a mile and a half long, and at the mouth three quarters of a mile broad; near which, on the right shore, is an inconsiderable island facing the ocean; a mile beyond, a high and slender rock emerges from the water, under whose surface lie concealed innumerable shelves. The depth between the rock and the island is 35 fathoms, with a gravelly bottom; at the mouth of the bay the water is only twelve fathoms deep, and shallows to seven farther on, with a bottom of fine sand, which, judging from the appearance of the shore, most probably covers the rocks at no great distance from lience, and occasioned the wrecking of Shebeshow's ship in 1790, who, having anchored in the bay to water, in his way from the island Badjak, was torn from his anchorage, and dashed against the shore.

On the inner shore of the bay lies the village Koshiga, consisting of three jurts, inhabited by thirty-two Aleutians, and two Russian hunters, left in the former year from a ship belonging to Shebeshow, on the western promontory of the island, while the ship itself wintered in the island discovered by the steersmat Pribylow.

Among the Aleutians who accompanied me from Akmagan was a Shaman, who undertook the restoration of a sick woman at the request of her relations. The Shaman and some of his country people seated themselves in a circle round the sick woman, and commenced a Shaman's hymn, accompanied by the drum; to this, after a short time; followed a profound silence, occasioned 
as the interpreter informed me, by the appearance of a spirit, which the Shaman began to supplicate for the sick woman. 'The spirit appeared rather obstinate at first; but at the continued entreaties of the Shaman at length yielded, adding, that the sick person suffered on account of her father's having, while on the whale fishery, smeared his arrows with the spinal marrow of that fish, and since he was now dead, an evil spirit was charged to obtain satisfaction from the daughter. The song now recommenced, and at the expiration of five minutes silence again prevailed. The Shaman then addressed the spirit, which now appeared to be under his controul, and informed the bystanders, that it was now in the bowels of the sick woman, for the purpose of minutely examining the disease, and removing the cause, from which in three days her restoration might be expected. This hope, according to the assurance of the Shaman, was confirmed by another spirit, whose opinion he had obtained; and thus concluded the exorcism. The Shamans never demand any compensation from the people, contentedly receiving what is given them, and never requiring offerings for the spirits.

On the 21 st, I proceeded farther with fine weather, and a calın sea; but towards noon a gale from the north-west blew. so hard, that I with difficulty reached the first promontory, four miles from Koshiga to the south-west, and anchored off a little village called by the Aleutians Umschaluka, by the Russians $\mathrm{Se}_{-}$ denka. It contains only twelve inhabitants. From the promontory is discernible a small rocky island, a quarter of a mile to the south-west and a mile to the west, a high rock surrounded with projecting cliffs.

On the third day the wind abated, and we made direct for the promontory of Amnak, distant from Sedenka about five miles to south-west $51^{\circ}$, and projecting far into the ocean with a range of high rocks. Between these two promontories are three open bays. The first, called Alimuda, commences immediately beyond Sedenka, penetrating two miles and a balf into the island in a westerly direction: the second is two niles in extent to the south-west; and the third is only divided from the second by a small slip of land, rumning in a south-easterly direction a mile and a quarter into the island.

When we came directly opposite to the promontory of Amnak, we perceived the entrance of the Bay of Tschernowsk, two miles and three quarters distant from the back part of the promontory. The entrance is defended on each side by a sort of promontory of high rock, surrounded with projecting cliffs. 'The shore between Amnak and Tschernowsk forms a slight curve far into the sea, is alternately rugged and mouutainous,

SARYTSCHEW, VOL. II.] 
but evidently lower than Amnak, which, when viewed from the ocesn, appears much elevated.

In the evening I arrived at the village of Tschernowsk, and on the following morning, notwithstanding the snow and rain, proceeded to survey the bay, which I found to be three miles and three quarters in length. The vater at the entrance is 15 fathoms, with a gravelly bottom; half a mile from the entrance is 35 fathoms deep; and a mile to the interior, only 18 fathoms. A mile and a half from the entrance is a small cove, penetrating a mile and a half to the west, 14 fathoms decp in the centre, with a muddy bottom, and might afford an excellent anchoring place. On the peninsula lies the village of Tschernowsk, consisting of one large and one small jurt, inhabited by thirty-nine Aleutians. 'The latitude of this place is $53^{\circ} 29^{\prime}$ '.

It was now my intention to visit the western promontory of Unalaschka, and proceed to my ressel round by the southern-shore; but being detained here three days by violent winds, and my provisions being on the decline, I was compelled to return.

On the ist of March I came to Koshiga, and was informed by the inhabitants, that not far from bere on the south-side of the island is another very large bay, whose very fine situation determined me to visit it, although $I$ was detained by wind and weather till the 6 th, when I proceeded in a treble-scated baidar, five miles along an inlet between a double row of mountains. The bay is called Kullilak, and although not so large as had been represented, is armirably defended on all sides against the sea; its length from south-west to north-west is a mile and a half. The entrance of the bay is towards the north-west $65^{\circ}$, its breadth between two naked projecting cliffs 100 fathoms. Its depth in the micille is 11 fathoms, and near the cliffs from four to five. Farther in the bay curves to north-east, and becomes broader but shallower; and near to a small rocky island, the water is only four fathoms and a half: the bottom is sandy. On the left shore is a sand-bank, with several naked and conceal I clifes which ships must guard against by keeping to the right sbore. After having passed this island, the bottom becomes muddy, and the depth of water increases to seven fathoms and a haif, and continues so to the furthest shore, when it recerves the waters of two brooks; one from the mountains, the other from a lake. The shore of the bay is in some places mountainous, in others high and rocky, then again forming a sloping plan. I then proceeded about three miles beyond the bay to a promontory on my right, to take a survey of the southem shore of Unalashka, and perceived that it has a southwesterly direction, and that the island is on this side very 
narrow. On the other side of the Bay of Kulliak to the northeast, the shore was concealed by he steep and projecting, romontory of Amtschik. The Alewians were of opmin, that it might be easy to run into the Bay of Kullilak from the open sea; but it may not be arriss to remark, that when you sail from the side east-south-east towards lie island, it appears to be divided into two islands.

Hazy weather and stormy winds detained me six days at the village of Koschiga, and oblinged me in ronsume my smali stock of provisions, after which I was compelled to make shift with dried fish, marime herbs, and vegetables, except once, when my host brought me some fresh fish, which they call Terpuge; but having neither bread nor salt I ate it with little relish.

The Aleutians becoming at length quite tired of bad weather, they one day collected themselves together men, women, and children, and repaired to an open field, where having ligthed a fire and turned themselves to the wind, they clapped their hands and screamed with all their might, quietly returning in the full expectation of a favourab!c change.

Towards evening, I suddenly heard the drum beating in a corner of the Jurt, and was informed by my interpreter, that the Tojas and Shamans were conjuring a spirit for favourable weather. At the expiration of a quarter of an hour the Shaman began to cry aloud, but soon ceased, and fell senseless to the ground. The terror became universal, a crowd surrounded him; sung a solemn lamentation, and conjured the spirit to spare the good Shaman; notwithstanding. which he continued some time motionless, but at last revived, and informed the bystanders " that he had summoned the spirit into his presence, and commanded him to send fine weather; but the spirit thought it by no means necessary, and he accordingly reproved him for his obstinacy and caprice, threatening, if he persisted in his refusal, to inform the people that he had not-sufficient power, which would certainly not be much to his honour. Upon this the spirit became so furious, that he feli on him, and continued to torment him until he became senseless, during which period it was manifested to hirm, that the weather would be no better until three days after the death of a certain woman, (whose name he mentioned), which wonld take place in the course of the summer. Then (added he) we might sail as far as Makuschinsk, but no farther, as we should there be again overtaken bv bad weather. He enjoined us thereiore, by no means to attempt proceeding farther, even if advised to do so by the imhabitants themselves. He then informed me that on my return to my vessel, I should not find my companions and 
people in a good state; but that although might lament having passed the whole svinter ou the island, yet we should put to sea at the commencement of the summer, and happily return to the place from which we came."

The latitude of this place is $53^{\circ} 31^{\prime}$.

On the 16th of March, I set out on my return to Makuschinsk; but being unable to proceed by water on account of the violent winds, I resolved to cross the mountains along the shore on foot, to Captain's Bay, which the Aleutians informed me was practicable during the summer in one day.

I went in my baidar to the extreme point of the Bay of Makuschinsk, where I landed and commenced my excursion with three Aleutians as guides. For above half the way, I proceeded with great facility; when I came to the back of a mountain, whose summit I could reach only by climbing a winding path, on the rocky shore of a river. The farther 1 advanced, the steeper it became; and being quite covered with hard snow, my labour was much augmented by being compelled with every step to stamp for myself a sure footing, Thus occupied, I fearlessly proceeded, unconscious of the height I had attained, until at last, finding I could go no farther, I saw to my dismay that $I$ stood on the brink of an immense precipice, whose sides were covered with rocks, at the bottom of which flowed a brook; On the sudden discovery of my situation, I was seized with such an irresistible dread, that I could proceed no farther, and resolved to retread the path I had ascended, in doing which I expected at every step to be precipitated headlong to the bottom. Fortunately, however, I arrived in safety at the place from whence $I$ set out, and was agan detained by wind and weather for the four following days.

On the 20th at midnight, a violent tempest began, and the wind blew on land with such fury, that no one could withstand it. On the following day the wind was less violent, but the sea remained much agitated. The lațitude of Makuschclinsk is $53^{\circ} 50^{\prime} 35^{\prime \prime}$.

The Toja of Makuschinsk, seeing my uneasiness at being thus long detained from my ship, and the great inconvenience 1 experienced for want of food, was at length moved with compassion, and informed me, that if the baidars were brought from the Bay of Makuschinsk to Beaver's-bay, it would be easy to pass to the vessels. By the aid of persuasion and presents, therefore, I at length prevailed on some Aleutians to, carry their own baidars and mine, across the land which parted the two bays, the distance being about three miles and a half.

I began my little voyage on the $23 \mathrm{~d}$, and reaching the vessels on the following day, found that during my absence the crews 
of the vessels had suffered so much from the scurvy, that eleven were dead on board the great ship, and three on board the small one. As 1 knew from experience, that this complaint is nuch relieved by change of air, I had the sick removed to the neighbouring villages with ali speed, where they were placed in jurts, previously cleaned and fitted for their reception. Besides this, the snow beswas to melt in various places, and enabled us to procure green-herbs tor their sustenance, which produced a visibie and rapid change. The chief cause of this malady was the damp and untavourable weather, which continued almost uninterruptedly during the whole of our stay at this place. Besides which the halt putrified food contributed not a little to increase the disorder, particularly bad rye-bread, which at best was tasteless, and soon became mouldy.

\section{CHAP. X. \\ DESCRIPTION OF UNALASCHKA.}

\section{T} HE Island of Unalaschka, or as the inhabitants denominate it Nagunalaska, is the largest in the whole chain of Fox Islands; it lies in the 54th degree of north latitude, and 194th degree of longitude east from the meridian of Greenwich. On the western side it is bounded by the island of Umnak, and on the east by the islands of Spirkin-Kigalga and Unalga. Its length from south-west to north-west, is seventy-four miles; and its greatest width tweuty; terminating to the west near Ummak, in a small promontory. It is surrounded by a number of bays, some of which penetrate so far into the land, as almost to unite with others on the opposite side. Among them are three of considerable magnitude, Ugadjach or Beaver's bay, running from the eastern side sixteen miles into the land; Makuschinsk on the western side ten miles, and a third running from Captain's-haven, seven miles and a half in land. All these have lesser bays, or creeks, adjoining them. 'They are all so deep in the middle, that a 60 fathom lne cannot reach the bottom; and in the sea, on the north and south side of the island, at the distance of six hundred feet from the shore, the water is above 100 fathous, while in the straits it is not more than 20 or 30 fathoms. The whoie island of Unalaschka is covered with mountains, whose summits are crowned with pointed and naked rocks; one of these mountans on the southern side is volcanic, and covered half-way up with moss and grass. The southern shore of the island is bounded by a chain of high rocks, but those at the northern extremity are rather lower than the others, and many slope towards the sea. The declivities of some of the mountains which are watered by brooks, produce! grass 
and heris. On the low spots are grown various sorts of plants, among which is the epilobium angustifolium, the branches which are numerous, and shoot annually from the parent root on stems above three feet high, with long narrow unequal leaves, the fower ronsisting of four small roundish patent lanreolated petals, with exht pedicles, the fruit consisting of a very long capsule of a cyliudrical form, with four valves. The seeds are numerous and oblong It grows in marshy places in the north of Europe. We also fomd the arbutus uva ursi, a creeping evergreen of inconsideruble size, the leaves of which are tough, thick, not juicy, and rounded with the corners bent inward. Detween these, campanuliterl flowers of a pink colour shoot forth, and are succeeded by tasteless round mealy berries, It grows in the fir-woods of the temperate parts of Russia, and is used in taming fine shins. The leaves are esteemed a powerfal diarctic, and the beries yield a serviceable dye.

I likewise met with raspberries of an amazing size, which, however, were watery and less inferior in havour to those of Europe. Among the edible roots are the Macarscha and Sarana, as also a sort of yellow carrot, which the inhabitants maintain has so great a power of strengthening the sight, that, if they eat largely of it at night, they can on the following morning discern the smallest object at an incredible distance; for which reason they generally eat of it previous to going on the chace.

'This island abounds with black, dark-brown, and light-grey foxes, but there are but few red ones. The Russian hunters catch them with traps; but in this open country they are by no means so good as those caught in the woody parts of Siberia; on which account they are much cheaper than the Siberian. Yet with all this disadvantage, the Russian merchants derive a considerable profit from this trade.

Besides the foxes there are no quadrupeds, except short-tailed mice, which burrow in the earth, where they find roots for their sustenance, and reside winter and summer; but they lay up no store for the former season.

Among the birds are eagles, with white heads and tails, hawks, woodcocks, and many kinds of small birds, some of which sing very well. Sea-fowls of different kinds are also numerous, as wilas, owls, \&c. which frequent the ledges of the rocks, and are eaught in their nests by the inhabitants, who convert their skins into garments as before described. The urilas are about the size of a wild goose, have long necks, sharp beaks, and black feathers, with a beautiful green ring romd their necks. The breasts and necks of the males are frequently variegated by a mixture of white feathers. Their legs are so near the tail 
that when they sit on the rocks, they appear to be standing; their bodies and necks being almost perpendicular. The owls are about the size of a duck; their breasts are white, and the rest of their feathers black. 'The' loporkas are nearly of the same size, their feathers being grey, their beaks red, broad, flat, and prominent; their eyes shaded with a row of white feathers, arched like eyekrows. The skins of these birds are much valued for their firmness, and are mostly made into garments for the men. Their beaks are used by the women for the decoration of their cloaths. There are no birds so dificult to shoot as these, from the extreme closeness of their plumage, which repels the shot; besides which, they frequently plunge into the water, and when they swin clap their wings as in flying. Two sorts of geese also occasionally visit the island; the first, which come from the southern countries in the middle of April, and reside on the lakes during the summer, are of a moderate size, with grey plumage, and the head and neck black; in September and October they disappear again, and are succeeded by others of a similar size, with an ash-coloured plumage speckled with white. These latter come hither from the north, live the whole vinter on the cliffs, that are often under water, and feed on the sea. weeds that abound in these parts.

In April, at the commencement of spring, they fly to the northern climates, where they probably breed. Yet we saw none of them in the country of the Tschukshens, whence should draw the conclusion, that they make the shore of North America their summer residence. The amphivions tribe of animals are less numerous here, than in the other Aleutian Islands. There were formerly otters in abundance, the skins of which were made into vests by the inhabitants; but since the stay of the Russians here, the number of these mimals has been greatly diminished, and they are now vary scarce. Sea-bears make their appearance in spring and autumn, but for a short time only, as they withdraw to the north in the spring, and to the south in autumn. Sea-lions however, frequent the detached rocks both summer and winter, thogghts not in great numbers.

Fish of different kinds are to be found round the island, as roach, cod, and another sort call terpuges, much variegated with yellow, green, and red spots. The rivers in June, July, and August, abound with ketas and the hump-backed salmon. Among the shell-fish are three soris of crabs, the first round and large, with long feet, very similar to those of the spider, and on that account called sea-spiders: the second in like manner round but smaller, with shorter legs and longer pincers; the third sort resembles the small river crabs, cx- 
cept that the tail is not covered with a shell, on which accomt they like to conceal themselves in the shells of snails, which they often drag about with them.

Judging from the barrenness, rude aspect, and deficiency of the necessary aticles of food, one would imagine, that this island was not destined for the habitation of man; but, according to the assurance of the Aleutians, it was sufficiently peopled before the arrival of the Russians, but hunger and other untoward accidents had reduced the population to less than one balf, and at present not more than one third was remaining. Their residences are all fised on the shore of the sea, and on the north, east, and west-side of the island, that to the south being uninabited; they reckon fourteen dwellingplaces in the whole, and thrce hundred and twenty-three male inhabitants. Each dwelling-place consists of two or three mud hovels of various sizes, tlre largest of which are nine fathoms long, and dere bruad.

The toor of such a hut is sunk somewhat under ground, and the roof is made of the floating wood which they fish out of the sea, covered with moss and grass. The light is admitted through some small openings in the roof, that serve also for the egress and ingress of the inlabitants, by means of a ladder, which consists of different steps cut out of a plank. About seven foot from the outer wall stakes are driven into the ground, which partly support the roof, and partly serve to mark out the partition for each family, in which, instead of beds, platted grass-mats are spread. They sit on these mats in the day-time to work, and sleep on them at night, using their cloaths for covering. They empty their dirty: slops and every filth, into the middle of this common dwelling, which becomes by that means excessively wet and muddy; and were there no openings in the roof, would soon occasion an insupportable stench and vapor. Each parition has a particular wooden reservoir for the urine, which is used both for dyeing the grass, and for washing their hands; but after cleaning the latter in this manner, they rince them in pure water, and dry them in the open air, by swinging them backward and forward.

They seldom make a fire in the jurt, except to cook the flesh of the sen-animals, and some sorts of fish : but they eat the cod-fish raw after cutting them into small pieces, which they consider as a preventive against the mischiet that they might otherwise receive from some small worms, supposed to be in the flesh of these creatures.

They obtain fire by. striking two flints over the nown of birds, sprinkled with brimstone, which instantaneously catch the falling sparks.

In the evening they burn train-oil in stone lamps, on which 
diccasion, they use dry moss for a wick. With this fire they not only light the jurt, but warm themselves, by taking it under their coats, and closing the opening, so that the heat cannot escape. In this manner they can make themselves as hot as if they were in a sweating-bath. 'The stone of which these lamps are made is very soft, and may be hollowed out with others of greater hardness, not merely for this purpose, but also for deep pots, in which they boil their fish. 'They use them however, but seldom, preferring mostly the iron and copper kettles, which they procure from the Russians.

The wooden utensils of these islanders are water-vats, made of split planks. The fat of the whales and the seals they preserve in bladders; the other dry provisions, in baskets, or sacks of braided grass.

Knives and axes they procure from the Russians; but they are not well acquainted with the use of the latter, to which they fasten a wooden handle, so that they can chip with them as with a hatchet, but neither split nor hew; they rive their large trees therefore by means of wooden wedges.

Nothing is more tedious and fatiguing, than their carpenter's and joiner's work, in making their baskets, their arrows, and the hulks of their baidars. One whole year and more is spent in building such a small boat, on which account they prefer purchasing it at a dear rate. The bare collecting together as much wnod on the shore as is requisite for a baidar, is attended with infinite toil and trouble. The main part is the keel, 21 feet in length, which is always composed of two or three pieces. To this they fasten, by means of split whalebone, ribs of willow and alder-branches, on the upper extremities of which they place a frame with cross-bars, which in the middle is a foot and half broad, and binds the wbole baidar together. Over the whole they stretch the hide of a sealion, or a large sea-dog, leaving on the top a round but smallish opening, in which the rower sits. This baidar is so light in all its parts, that altogether it does not weigh much above thirty pounds. The paddles are very long, and have shovels at both ends. They are held by the rowers in such a manner, that they can row alternately with one shovel on the one side, and another on the other.

The weapons of the islanders consist merely of darts and spears, which, as they use them for different purposes, are af various sizes. The first sort, which are used against men and animals, are four foot long, having a bit of lava aftixed as a point, which is an inch and half long, and three quarters of an inch broad. The second sort is smaller than the first, and is only used zgainst animals; points of bone instead of lava are tied ou them 
with sinews. The third sort, which is used for killing birds, is equal to the first in size, and provided with four barbed bonepoints. The fourth sort is nine feet long, and also used against animals, having at one extremity a bony point, to which is tied a thong made of sinews, that is wound twice round the middle of the spear. The other extremity is adorned with a bush of eagle's feathers. The fifth sort is four feet four inches long, having a bony point, and in the middle an inflated bladder, to keep the mortally wounded animal from sinking. The boards with which these darts were thrown are about a foot and half long; one end is fitted for a handle, and at the other end a bone is fastened in like a nail, on which the dart is placed for being thrown.

The dasts and boards are dyed with a red stuff, collected from the sides of the rocks, and dissolved in water secreted from blood, by which it is made proof against rain or salt-water.

'The blood for this purpose they get from their noses, which they prickle with a blade of grass, until they have procured a sufficiency. On any excursion to sea, they fix their darts behind and before them, in thongs fastened to the baidar.

The darts, which the Aleutian always endeavours to get again, he throws with his right-hand, while with his left he manages the baidar.

He is so dexterous in the government of his bark, that the lightest sloop would certainly not be able to overtake him; for we had the experience of the Aleutians coming up with our vessel in their baidars, when it was going at the rate of four leagues an hour.

Mears says in his Travels, that the Aleutians could turn themselves over in their baidars, and regain their position at pleasure; but this is not the case. Whenever they are so unfortunate as to be overturned, their death is inevitable, if no one be at hand to assist them; on which account they take the precaution of going in companies, and put in stones for ballast when they have no other load. When they have occasion to. stop for any purpose, they bind all their baidars close together; and if they wish to land safely in a violent storm, they must have assistance from the shore to draw their baidars to land.

Expert as these islanders are in the management of their baidars, they are incapable of swimming; and, from what I observed, are not in the habit of bathing, which may be owing to the severity of the climate.

Respecting the appearance, dress, and labours of the Aleutians, nothing is to be added to whiat has already been said on that subject, in the first chapter of this volume. It now renains to mention the different opinions relative to their origin, and 
to take notice of their superstitions, rites, and funeral solemnities. It must of course be very difficult to trace the origin of a people so remote and savage, which has no other docunents than what oral tradition affords, blended as it is with a thousand fables, and confused by a thousand contradictions. In such cases, the best means of getting at the truth, is to compare the customs, mamers, and language of one people with those of another, and from thence to draw our conclusions. At the same tinie, I have not neglected any information which could possibly be collected from their incongruous relations, and for that reason took particular pains to converse with ihe old men on this subject.

From the thin population found in these islands, I concluded that they could not have been long inhabited, and that the inhabitants probably knew something by tradition of the place whence they came; but I could gain no satisfactory answer to my enquiries; for the two tales related to me by a couple of old men, did not at all accord, and afforded me no che to a farther solution. "One informed me, that Grod, after the creation of these islands, also created men who were originally immortal, and when they had reached old age, went on a lofty mountain and threw themselves into a lake, from whence they came out possessed of renovated youth; but that God in the mean time fell in love with one of their virgins, and took her to be his wife, who once, in a familiar conversation, reproached him with having committed a fault in the creation of the Aleutian Islands, by giving them so many mountains, and no wood. Upon this God was extremely indignant, and killed her brother, which was the introduction of mortality among men."

According to the other fable, the Aleutians are said to descend from a dog, that fell from the sky on the Island of Umnak, which had two puppies, a male and a female, that had dog's paws; but the progeny of these were perfect men. As they multiplied, and the island became too small for them, dissensions arose, and they were compelled to seek habitations elsewhere, some going eastward to Cape Naksa, others to the cluster of islands in the west, whence they received various appellations. The inhabitants of Atta, are called Sagignas; those of the Andrejenow Islands Negochas; those of the Rat Islands, Kogochas; those of the Volcanic Islands, Akoganas; those of Ummak and Unalaschka, Kagulangas; those of Umuak and the other circumjacent isiands, Kigegonas; those of Umnak, Sannach, and Uega. Kagantagumas; those of Karljak, Kanagas; those of Cook's River, Kenaizas; and those of Prince 'William's Bay, Schugatschas. Not a single Aleutian can assign a reason for these different appellations; notwithstanding which, all these 
people, except the Kenaizas, Kenagas, and Schugatschas, have the same customs, dress, and even language, with a few variations in some words, and in the pronunciation, which does not, however, prevent them from understanding each other.

On the islands, where the Russian merchant-ships anchor, as on Unalaschka, Umnak, and the Andrejenow Islands, the people are more civilized. Some of them speak good Russian, and many are baptized in the Christian Faith. But in the other islands, they are as rucle and savage as ever. They acknowledge a God indeed, as the alnighty and universally beneficent Being, but regard all worship, sacrifice, and prayer as superfluous, from the idea that God knows better thain they, what is good for them, and will grant it without their request.

They consider misfortunes and diseases as the effects of wicked spirits, and on such occasions have recourse to their Shamans, who assume no particular garb, nor use any extravagant gestures in their exorcisms, but calnly sing with the other Aleutians, sitting in one posture, and sometimes beating on a drum. Their drums are not large, being the same as those used for every other song and dance. 'The Aleutians take one, two, or even three wives, as they are in a capacity of supporting them. They have no nuptial ceremonies. The bridegroom commonly treats with the parents for the bride, and promises what he thinks he can afford, either in cloaths, baidars, or what are termed Kalga, which is prisoners made in the other islands, or destitute orphans, who are consigned over to a rich Aleutian, to labour for their bare sustenance, and may be transferred to anothep on the same conditions. If the parties are agreed, the bridegroom begins to visit his bride, and frequently spends whole days with her, in the character of a lover. If they have any regard for each other, the bridegroom either takes her to his house, or repairs for a constancy to her dwelling. If they live in harmony, the father now on his part makes presents to the son-in-law ; if, however, the husband be not satisfied with his wife, he can send her away, but has no right to demand his own presents back; on the other hand, if the woman will not live with him, he is at liberty to take. from his father-in-lav all that he had given for her.

No man is allowed to sell his wife without her consent; but he can resign her over to another, either for a term of years, or for a continuance, which is not unfrequent. The Russian hunters, in particular, make use of this privilege, and take Aleutian women or girls for a time, for which they give a trifling compensation. But it never happens that a woman grants her favours to another without the consent of her husband; for in this barter of 
their persons, they are not infuenced by love, but a desire of gain. Nor was this custom so frequent, before the arrival of the Russian hunters, and is not practised by any whose thirst of gain has not stitled their natural sense of shame; there are, however, many who would not carry on so disgraceful a com.merce, for any emolument whatever. I was told, that formerly this custom was not practised for money, but from a sort of compassion, and a cordial attachment to an individual, who, on his return after a long absence, was allowed to sleep one night with every female, married and unmarried, in the jurt. Hence it is, that the man, who can never with certainty claim the children as his own, that are born by his wives, has not an equally unlimited power over them with the mother; nay, that the uncle on the mother's side has more authority than he.

The children of one father by different mothers are not regarded as brothers and sisters, and are accordingly permitted to intermarry; but the case is reversed, with respect to those by one mother and different fathers. The distribution of the property on the death of the father is regulated by the relatives, who ustally leave the greatest part for the widows and children, and take the rest for themselves.

$I$ had no opportunity of witnessing a burial; but $I$ learnt from the inhabitants, that a custom formerly prevailed at the decease of a Toja, or any other man of consequence, of burying one of his servants with him. But now this barbarous custom is done away; and the baidars, darts, and other utensils only of the deceased are put in his grave. The entrails are taken out of the corpse; which is stuffed with hay. Persons in mean circumstances are put without any ceremony into the ground, or the cavities of the rocks, but the rich are laid in tombs, made of wood, expressly for the purpose. Into these earth is first shaken, and then covered with grass mats and skins, upon which the body is laid, and bound with thongs, in the position in which one usually sits in the baidar, with the feet approaching towards the breast, and the hands folded round the latter. Another mat is then laid over it, and covered with another layer of earth, upon which broken pieces of the baidar are placed. If the wife has an affection for the deceased, she cuts the hair off the crown of her head, as a token of her grief, and mourns for him several days; some. times carrying it so far as to keep the body for wceks together in the jurt, for which purpose a frame is erected of a suitable size, in the shape of a prism, and covered with skins. Tile corpse is nixed into this case, as in a sitting posture, and remains there in a detached comer of the jurt, until the unsupportable smell renders it necessary for it to be buried. But little chil- 
diren for whom such a frame can be made firmer and closer, are kept sometimes a whole year and even longer, until another comes into the world to supply its place. Such coffins are decorated by the mothers with enamel beads, thongs, and bird's bills, and humg over their beds.

I shall now conclude my description of these islanders with some few remarks on their capacities, propensities, and morals. The Aleutians have a goor natual understanding, very considerable talents, and a quick compreliension; some of them were very expert at cards, draughts, or even chess, in which none of our companions could excel them. 'They are indebted for these acquirements to the Russian hunters, who, without intending any good to the islanders, sought by this means to enliven the leisure time, which hung heavy on their hands. Had they however, chosen to turn their thoughts to the introduction of agriculture and every rural occupation, they would have obtained their own object more effectually, and enjoyed the gratifying reflection of having contributed to the civilization of a savage people.

The inhabitants are very quiet and peaceable among each other, at least as far as we can judge from experience, having never observed the least discord among them, during our whole star.

On my journey round the island, they every where received me with the greatest friendliness, and entertained me in the kindest manner, so that I may with justice place hospitality among the principal virtues of this rude people; it being displayed to all who pass through their places, without regard to relationship or acquaintance; for I myself was witness to their sharing the balf of their own provisions with perfect strangers from other islands, and that too without receiving any compensation. At the same time they have the commiendable custom of relieving every one from the painful necessity of asking for any thing, by setting before the weary traveller whatever they possess, as suon as he enters their jurt and is seated. In addition to this, the Aleutians form an exception to savages in general, and particularly those inhabiting the Eastern Islands, that they are not thieves. Nor have I observed any other evil propensities among them, but indolence and ingratitude. They never betray any vehement emotions, nor do their countenances ever indicate either vexation, melancholy, or joy, on any occasion, however extraordinary. On the return of a relative from a distance, he is received with as much unconcern as if he had never been absent. He likewise goes himself without saluting any one, or speaking a word, into his partition of the jurt, seats himself by his relations or wives, and takes off his 
travelling attire. If he asks for any thing to eat, it is set before him, and if he is cold he has a lamp given him; after which, he begins relating sone particulars of his journey, and they on their part inforn him of what has passed at home during his absence; but all this goes forward without the slightest indication of curiosity or interest.

\section{CONCLUSION.}

Tн $\mathrm{E}$ reader will perhaps not be unwillingly detained a few moments longer at the close of my narrative, to learn the fate of my partners in this toilsome expedition.

'The chief of the expedition, Captain Joseph Billings, retired on a pension as commodore, in the year 1797 , and now resides at Moscow.

Robert Hall, captain, now rear-admiral and knight, residing at Petersburg.

Christian Behring, captain, a grandson of the famous navigator, from whom Behring's Strait receives its name, died of a consumption in August 1803, in the forty-third year of his age, as a pensioned major-general of the fleet.

Anthony Batakow, steersman, supposed to be dead.

Sergei Batakow, steersman, dead.

Kondratow, second steersman, his fate totally unknown.

Aphanassi Bakow, boatswain, is now boatswain with the rnok of lieutenant, in the service of the fleet at Cronstadt, and his obtained the Wladimi order of the fourth class.

Michael Rohbeck, first-surgeon, is now first-plysician of the hospital erected some time since at Petersburg, by her majesty the empress.

Surgeon Allegretti, so honourably mentioned by Mr. Lesseps, in his Journey through Siberia, was some years first-surgeon in the service of her majesty the empress, and had narried it grand-child of the famous Euler, but died in the year 1799; in consequence of the bite of a mad dog, in the most melancholy condition.

Lehmann, first surgeon's assistant, is now living as first surgeon of one of the gallies.

Wassilei Woloschenow, second surgeon's assistant, received a post in the government of Woronesch.

Martin Sauer, secretary, known by his description of this Voyage, in his native language the English, is now a broker in the Petersburgh exchange.

Joseph Edwards, mechanic, is an overseer, in the silk ant cotton manufactory, erected by her majesty the empress; at Alexandrousk, not far from Petersburgh. 
M. Woronin, draughtman, follows his profession in the service of the Admiralty.

Serjeant Bakuliu died as lieutenant at Ochotsk.

Doctor Merk, a man combining an almost puerile timidity with extraordinary intelligence, died in the year i797. He understood the Jakutish language very well, partly from his having married a native of Jakutsk, who was descended from Russian parents. His widow is still living. The results of his observation and researches, together with that of the other voyagers, were consigned over to the celebrated Pallas.

Daniel Haus, steward, died during the expedition.

John Main obtained a situation some years ago in an ironfoundery of Mr. Gascoyne, at Petrosawodsk.

Charl s Krebs died as bookbinder to the Admiralty, some years ago.

M. Wassilei Siwzow, the chaplain, remained after the expedition at Jakutsk, whence he had been taken, and is said to be still alive.

Captain Timophei Schnalew died during the expedition at Ochotsk.

Secretary Jerlin remained in Siberia, and is still living.

The provincial secretary Karpow died at Irkutsk.

Gawrila Pribylow, steersman, the discoverer of the islands named after him, remained in Siberia; and if still living, must be a very old man.

With regard to myself, it may suffice for the reader to know that I am still in the service of his Imperial Majesty, with the rank of Admiral, and member of the Board of Admiralty. 



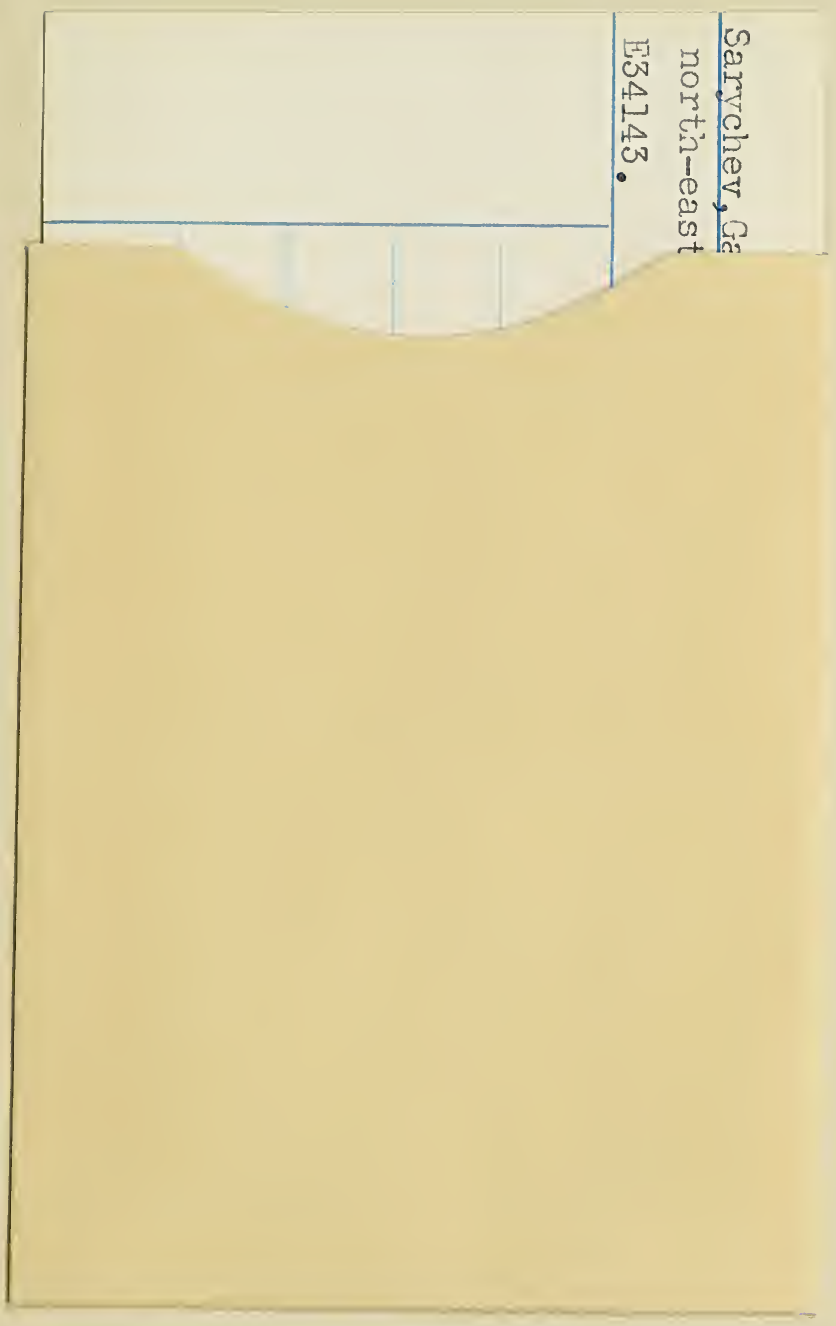


